\title{
LITERATURA, LEITOR E ESTÉTICA NAS PRÁTICAS LITERÁRIAS
}

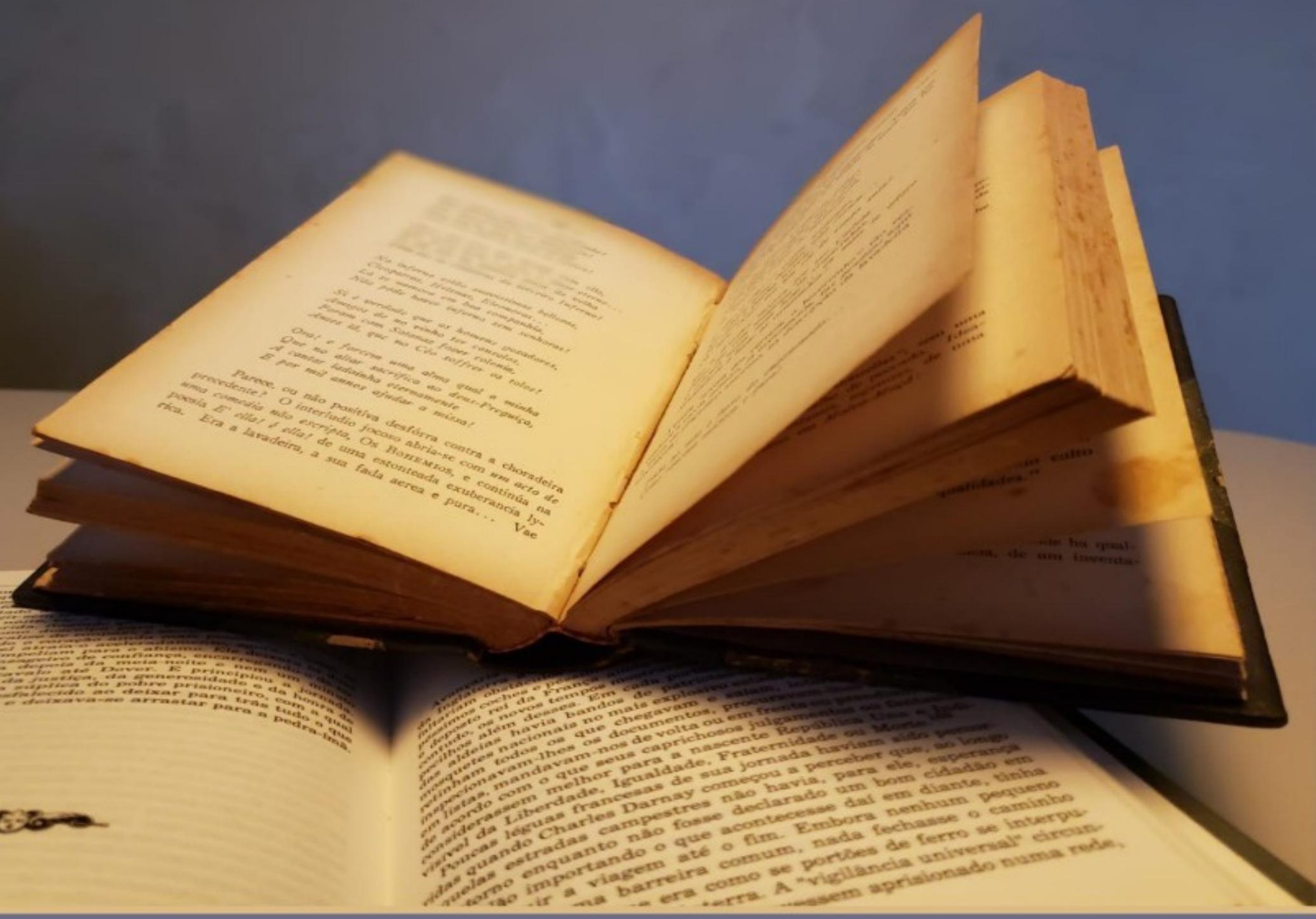

Karla Menezes Lopes Niels Iza Reis Gomes Ortiz Marlise Buchweitz [Organizadoras] 


\section{LITERATURA, LEITOR E ESTÉTICA NAS PRÁTICAS LITERÁRIAS}

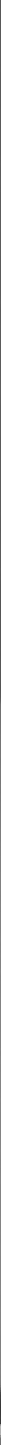

Karla Menezes Lopes Niels Iza Reis Gomes Ortiz Marlise Buchweitz [Organizadoras] 


\section{CONSELHO EDITORIAL}

Prof. Dr. Adilson Tadeu Basquerot e Silva

UNIDAVI/SC

http://lattes.cnpq.br/8318350738705473

Profa. Msc. Jesica Wendy Beltrán

UFCE- Colômbia

http://lattes.cnpq.br/0048679279914457

Profa. Dra Fabiane dos Santos Ramos UFSM- Santa Maria/RS

http://lattes.cnpq.br/0003382878348789

Dr. João Riél Manuel Nunes Vieira de

Oliveira Brito

UAL - Lisboa- Portugal.

http://lattes.cnpq.br/1347367542944960

Profa. Dra. Alessandra Regina Müller Germani

UFFS- Passo Fundo/RS

http://lattes.cnpq.br/7956662371295912

Prof. Dr. Everton Bandeira Martins

UFFS - Chapecó/SC

http://lattes.cnpq.br/9818548065077031

Prof. Dr. Erick Kader Callegaro Corrêa UFN- Santa Maria/RS

http://lattes.cnpq.br/2363988112549627

Prof. Dr. Pedro Henrique Witchs

UFES - Vitória/ES

http://lattes.cnpq.br/3913436849859138

Prof. Dr.Thiago Ribeiro Rafagnin UFOB

http://lattes.cnpq.br/3377502960363268
Prof. Dr. Mateus Henrique Köhler

UFSM- Santa Maria/RS

http://lattes.cnpq.br/5754140057757003

Profa. Dra. Liziany Müller Medeiros

UFSM- Santa Maria/RS

http://lattes.cnpq.br/1486004582806497

Prof. Dr. Camilo Darsie de Souza

UNISC- Santa Cruz do Sul/RS

http://lattes.cnpq.br/4407126331414

Prof. Dr. Dioni Paulo Pastorio

UFRGS - Porto Alegre/RS

http://lattes.cnpq.br/7823646075456872

Prof. Dr. Leonardo Bigolin Jantsch

UFSM- Palmeira das Missões/RS

http://lattes.cnpq.br/0639803965762459

Prof. Dr. Leandro Antônio dos Santos

UFU- Uberlândia/MG

http://lattes.cnpq.br/4649031713685124

Dr. Rafael Nogueira Furtado

UFJF- Juiz de Fora/MG

http://lattes.cnpq.br/9761786872182217

Profa. Dra. Angelita Zimmermann

UFSM- Santa Maria/RS

http://lattes.cnpq.br/7548796037921237

Profa. Dra. Francielle Benini Agne

Tybusch

UFN - Santa Maria/RS

http://lattes.cnpq.br/4400702817251869

Copyright (C) Arco Editora, alguns direitos reservados.

Copyright do texto (c) 2021 os autores e as autoras.

Copyright da edição (c) 2021 Arco Editora. 
Diagramação e Projeto Gráfico : Gabriel E. Machado

Imagem Capa: Karla Menezes Lopes Niels.

Revisão: dos/as autores/as.

Dados Internacionais de Catalogação na Publicação (Câmara Brasileira do Livro, SP, Brasil)

Literatura, leitor e estética nas práticas
literárias [livro eletrônico] / Karla Menezes
Lopes Niels, Iza Reis Gomes Ortiz, Marlise
Buchweitz [organizadoras]. -- 1. ed. --
Santa Maria, RS : Arco Editores, 2021.
PDF
Bibliografia
ISBN 978-65-89949-16-9
1. Literatura - Estética 2. Literatura - História
e crítica 3. Leitores I. Niels, Karla Menezes Lopes.
II. Ortiz, Iza Reis Gomes. III. Buchweitz, Marlise.
21-79578 CDD-800

Índices para catálogo sistemático:

1. Literatura 800

Maria Alice Ferreira - Bibliotecária - CRB-8/7964

\subsection{9/978-65-89949-16-9}

O padrão linguístico-gramatical, bem como o sistema de citações e referências bibliográficas são prerrogativas de cada autor. Da mesma maneira, o conteúdo e teor de cada capítulo é de inteira e exclusiva responsabilidade de seu respectivo autor. 


\section{AGRADECIMENTOS}

Agradecemos à Arco Editores pela possibilidade de organização do e-book Literatura, Leitor e Estética nas Práticas Literárias, bem como a cada um dos autores que contribuíram com suas pesquisas, reflexões e análises teóricas, de forma a tornar possível a publicação que ora apresentamos, cujo objetivo é dar a ver as múltiplas visões e interpretações que o texto e a prática literária permitem aos leitores. 
Ela [a literatura] não corrompe nem edifica, portanto; mas, trazendo livremente em si o que chamamos o bem e o que chamamos o mal, humaniza em sentido profundo, porque faz viver. (Antonio Candido) 


\section{APRESENTAÇÃO}

Karla Menezes Lopes Niels

Iza Reis Gomes Ortiz

Marlise Buchweitz

Definir Literatura não é fácil, visto que seu conceito, sempre fluido, depende do contexto cultural em que se insere; mas é incontestável se tratar de uma manifestação artística que, seja oral ou escrita, acompanha a humanidade desde tempos imemoriais, refletindo e problematizando o homem e seu meio.

Consoante a isso, Antonio Candido (2011, p. 193) defendeu que a literatura é um "direito inalienável" do ser humano, justamente porque através dela nos humanizamos, ao tomarmos consciência de nossa posição no mundo e na sociedade. Ademais, como salienta, a literatura "nos deixa mais capazes de ordenar a nossa própria mente e sentimentos; e, em consequência, mais capazes de organizar a visão que temos do mundo" (CANDIDO, 2011, p. 179). Não que a literatura deva nos ensinar algo, como o era na Grécia Antiga, ou como o apontam os documentos que norteiam o ensino brasileiro; no entanto, ao apresentar a vida humana em toda a sua complexidade, possibilitando a experiência profunda do viver, não apenas pelo tratamento temático das obras, mas, especialmente, pela forma como a linguagem é elaborada, ensina-nos a viver, pois, como bem disse Umberto Eco "esta educação ao Fado e à morte é uma das funções principais da literatura" (ECO, 2003, p. 22 - tradução livre ${ }^{1}$ ).

Semelhantemente, Tzvetan Todorov (2009) diz que "a literatura amplia o nosso universo, incita-nos a imaginar outras maneiras de concebê-lo e organizá-lo" (p. 23), o que significa dizer que, através da experiência com o texto literário,

1 No original: "[...]questa educazione al Fato e alla morte sia una delle funzioni principali della letteratura" (ECO, 2003, p. 22) 
o leitor pode vê-lo com outros olhos, ampliando as possibilidades do seu próprio existir. De fato, independentemente do gênero, seja um romance naturalista, um romance histórico, um conto fantástico, uma narrativa infantil e/ou juvenil, um poema concreto, ou uma narrativa transmídia, a literatura nos descortina novos mundos ao nos permitir problematizar este que conhecemos e concebemos como real.

Portanto, consideramos a dialogicidade da escrita e da leitura de um texto literário, posto que, conforme Bakhtin (1997), o leitor não é um ser passivo, que apenas recebe a comunicação; os indivíduos recriam e atualizam seus sentimentos, ao entrarem em contato com o texto literário, mesmo estando em períodos históricos, culturais e sociais distintos do autor. Sendo assim, salientamos a importância do ensino de Literatura, não somente para a construção de visão crítica dos aprendizes, mas para o despertar de emoções e sentimentos. Neste sentido, escritor, texto e leitor dialogam entre si, formulando ideias e concepções construídas a partir do próprio contexto de vida do que lê (JAUSS, 1994).

A partir desta percepção do texto literário como aquele que pode desconstruir e reconstruir o sujeito, mas, ainda assim, cientes de que a literatura não se justifica apenas por finalidades alheias à sua função estética, o livro Literatura, Leitor e Estética nas práticas literárias acolheu artigos que versam sobre a instituição literatura, em suas estéticas e práticas, e, com isso, suscita discussões e reflexões acerca dessa e de suas concretudes, em uma sociedade hipermoderna como a que vivemos, que demanda novos olhares e práticas, cujas múltiplas vozes leitoras e autoras contribuem, hoje, para sua formação.

Nesse respeito, o primeiro capítulo deste livro, intitulado A escrita feminina no jornal $O$ Exemplo: vozes-mulheres em cena (Porto Alegre/RS, 1902-1927), Ricardo Costa de Sousa e Samanta Barreto Matos de Souza, para falar sobre a autoria feminina e a resistência do que chamam de "vozes-mulheres", analisam alguns dos poemas de autoria feminina publicados no jornal $O$ Exemplo, de Porto Alegre, ao início do século XX. 
No segundo capítulo, Estudo do conto "Ninho de Periquitos" de Hugo de Carvalho Ramos: uma experiência literária com estudantes do $4^{\circ}$ ano do ensino fundamental, de Rodrigo Milhomem de Moura, Ruskaia Fernandes Mendonça e Alexandre Ferreira da Costa, propõe a discussão do uso das histórias em quadrinhos $(\mathrm{HQ})$ como recurso didático para desenvolvimento da leitura e do letramento literário. Para isso, traz um relato de prática de atividades com crianças do $4^{\circ}$ ano do ensino fundamental, realizadas no âmbito do Projeto Ponto de Apoio do Centro de Ensino e Pesquisa Aplicada à Educação da UFG.

O terceiro capítulo, A importância do espaço no naturalismo literário, de Márnei Consul da Silva, propõe refletir sobre os conceitos de espaço e ambiente. Para tal, analisa comparativamente as obras $O$ cortiço, de Aluísio Azevedo; $O$ Ateneu, de Raul Pompeia; e o Bom-Crioulo, de Adolfo Caminha; a fim de considerar como o espaço condiciona as ações dos personagens e como atenção à essas categorias auxiliam o leitor no entendimento de obras de cunho naturalista.

No quarto capítulo, Um olhar sobre alguns aspectos temáticos e estruturais em o Berço do Herói de Dias Gomes, de Rondinele Aparecido Ribeiro, apresenta uma análise da peça O Berço do Herói, escrita por Dias Gomes. A proposta do texto perpassa pela análise estrutural em seu contexto de produção e publicação. A presença do conteúdo político na peça nos remete à contemporaneidade, o que nos permite refletir a partir de um teatro pautado na visão crítica da realidade, como afirma o autor do artigo.

No capítulo Escrita como performance: fragmentos e sínteses de conexão, o autor, Waldenilson Teixeira Ramos, discute sobre seu próprio movimento de escrita, refletindo sobre o escrever, numa análise de si mesmo enquanto leitor de textos e de mundos. A partir do livro de autoria própria intitulado Fragmentariedades de Sentidos Para Novas Conexões, Waldenilson pensa os sentidos de leitura dos "fragmentos" que produz e da "multidão" que se insere nos escritos, a partir dos encontros teóricos e vivenciais que lhe permitem a construção de textos ficcionais. 
O capítulo 0 fantástico em Rubião: proposta para o ensino de literatura, de Luciana Morais da Silva e Karla Menezes Lopes Niels, reflete acerca dos problemas inerentes ao ensino de literatura, especialmente no Ensino Médio, bem como oferece possíveis abordagens de leitura em sala de aula, a partir da literatura de cunho fantástico, outrora relegada ao esquecimento, porém importante aliada no desafio de instigar os alunos à leitura literária.

Em Era uma vez: um projeto que forma leitores e mediadores de leitura, de Arthur Scapini e Analoren Fernandes, os autores nos convidam a entrar em um Projeto de Extensão que tematizou a leitura e os leitores. O objetivo do projeto foi despertar a leitura e a criação de histórias juntamente com o público e também intencionou a formação de mediadores de leitura, já que o foco era a contação de histórias por parte dos acadêmicos integrantes do projeto.

O capítulo "Defronte do inimigo sarraceno": a (des)construção da identidade muçulmana em Os Lusíadas, de Mauricio Alves de Souza Pereira, nos instiga a fazermos uma leitura analítica sobre a construção e a desconstrução da identidade muçulmana presente no épico Os Lusíadas, de Luís de Camões, por meio do plano discursivo.

Por fim, o nono capítulo, A vida nua em "Mineirinho" de Clarice Lispector, de Maria da Luz Lima Sales e Dianily de Almeida, baseia-se nos pressupostos teóricos de Giorgio Agamben acerca da "vida nua", no qual fez-se um estudo tendo como norte o conto "Mineirinho", da escritora Clarice Lispector. Como resultados destaca-se que a sociedade divide os indivíduos em duas categorias: aqueles que têm os direitos respeitados e os que não possuem tal prerrogativa, tratando os inúmeros "mineirinhos" como seres que podem e devem ser descartados sumariamente, por não terem alcançado o patamar de seres humanos, cujas existências, ao contrário das "vidas plenas", não se mostrariam importantes a ponto de serem preservadas.

No alinhavo destes textos, a partir da temática proposta, convidamos vocês, leitores, a refletirem junto com os autores de cada artigo sobre as possibili- 
dades que o universo da Literatura nos descortina. No ordenamento da mente e pensamento e na organização da visão de mundo a que nos permitimos através da leitura, conforme sugerido por Antonio Candido (2011), esperamos que a reflexão teórica ora apresentada contribua para que as práticas literárias sejam sempre, além de deleitosas, promotoras de reflexão crítica e de promoção de conhecimento.

\section{Boa leitura!}

\section{REFERÊNCIAS}

CANDIDO, Antonio. "O direito à Literatura". In: CANDIDO, Antonio. Vários Escritos. Rio de Janeiro: Ouro sobre o Azul, 2017. p. 171-194

BAKHTIN, Michael. Problemas da poética de Dostoievski. $2^{\mathrm{a}}$ ed. Rio de Janeiro: Forense Universitária, 1997.

ECO, Umberto. Sulla Letteratura. Milano: Tascabili Bompiani, 2003.

JAUSS, Hans Robert. A história da literatura como provocação à teoria literária. Tradução de Sérgio Tellaroli. São Paulo. Ed. Ática, 1994.

TODOROV, Tzvetan. Literatura em Perigo. Trad. de Caio Meira. Rio de Janeiro: DIEFEL, 2009. 


\section{SUMÁRIO}

\section{CAPÍTULO 1}

A ESCRITA FEMININA NO JORNAL O EXEMPLO: VOZES-MULHERES EM CENA (PORTO ALEGRE/RS, 1902-1927) 14

Samanta Barreto Matos de Souza

Ricardo Costa de Sousa

Doi: 10.48209/978-65-89949-16-1

\section{CAPÍTULO 2}

ESTUDO DO CONTO "NINHO DE PERIQUITOS" DE HUGO DE CARVALHO RAMOS: UMA EXPERIÊNCIA LITERÁRIA COM ESTUDANTES DO $4^{\circ}$ ANO DO ENSINO FUNDAMENTAL

Rodrigo Milhomem de Moura

Ruskaia Fernandes Mendonça

Alexandre Ferreira da Costa

Doi: 10.48209/978-65-89949-16-2

CAPÍTULO 3

A IMPORTÂNCIA DO ESPAÇO NO NATURALISMO LITERÁRIO. .50

Márnei Consul

Doi: 10.48209/978-65-89949-16-3

CAPÍTULO 4

UM OLHAR SOBRE ALGUNS ASPECTOS TEMÁTICOS E ESTRUTURAIS EM O BERÇO DO HERÓI, DE DIAS GOMES.

Rondinele Aparecido Ribeiro

Doi: 10.48209/978-65-89949-16-4

CAPÍTULO 5

ESCRITA COMO PERFORMANCE: FRAGMENTOS E SÍNTESES DE CONEXÃO. 
CAPÍTULO 6

O FANTÁSTICO EM RUBIÃO: PROPOSTA PARA O ENSINO DE LITERATURA .........................................................................................100

Luciana Morais da Silva

Karla Menezes Lopes Niels

Doi: 10.48209/978-65-89949-16-6

CAPÍTULO 7

ERA UMA VEZ: UM PROJETO QUE FORMA LEITORES E MEDIADORES DELEITURA

Arthur Scapini

Analoren Fernandes

Doi: 10.48209/978-65-89949-16-7

CAPÍTULO 8

"DEFRONTE DO INIMIGO SARRACENO": A (DES)CONSTRUÇÃO DA IDENTIDADE MUÇULMANA EM OS LUSÍADAS.......................................130

Mauricio Alves de Souza Pereira

Doi: 10.48209/978-65-89949-16-8

CAPÍTULO 9

A VIDA NUA EM “MINEIRINHO” DE CLARICE LISPECTOR.

Maria da Luz Lima Sales

Dianily de Almeida

Doi: 10.48209/978-65-89949-16-0

SOBRE AS ORGANIZADORAS .160

SOBRE AS AUTORAS E AUTORES .163 
dol $10.48209 / 978-65-89949-16-1$

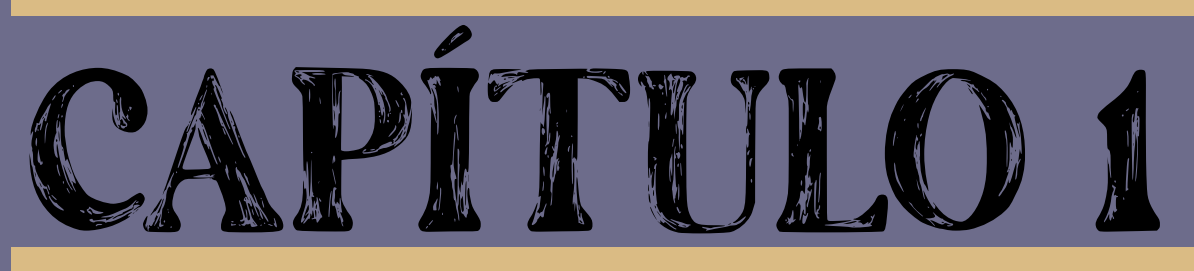

\section{A ESCRITA FEMININA NO JORNAI O EXEMPLO:} VOZES-MULHERES EM CENA (PORTO A A.FGRE/RS, 1902-1927)

Samanta Barreto Matos de Souza Ricardo Costa de Sousa 


\section{INTRODUÇÃO}

Às mulheres foram negados muitos direitos básicos desde o início das sociedades patriarcais. A voz masculina precisava se sobressair para que esse sistema se instaurasse e, com isso, apagar tudo o que era relacionado ao feminino. À mulher é dado somente o ofício doméstico, parideiro e dos cuidados com a família e, consequentemente, a invisibilidade diante da vida pública (MURARO, 2002). As vozes-mulheres, no entanto, nunca se apagaram de todo. Em todas as épocas elas se levantam e ecoam seus gritos de permanência no mundo e de resistência. A esse respeito Certeau afirma que "a escritura acumula, estoca, resiste ao tempo pelo estabelecimento de um lugar e multiplica sua produção pelo expansionismo da reprodução" (CERTEAU, 2014, p. 245). O que sugere pensarmos que o desafio deste texto é realizar uma operação historiográfica que se reconheça um outro tempo, a escrita feminina a partir da seleção de algumas poesias que ainda resistem, seja no seu formato físico ou digital.

Dessa forma, o objetivo do texto é apresentar o conteúdo dos poemas publicados no jornal $O$ Exemplo, relacionado à escrita feminina. Com base nessa definição, nos propusemos a inscrever as vozes-mulheres em cena como práticas de escrita não tuteladas. Tal empreendimento partiu do gênero textual poesia sob inspiração dos pressupostos teóricos e metodológicos de Bakhtin (2010) e de Barthes (2013) quando abordam o viés semântico e social circunscrito na palavra, bem como na língua. Partiu, também, dos pressupostos teóricos e metodológicos inscritos em Pesavento (2008) quando trata das pesquisas historiográficas no campo da História cultural que, conforme Pesavento (2008, p. 42) "seria, pois, decifrar a realidade do passado por meio das suas representações, tentando chegar àquelas formas, discursivas e imagéticas, pelas quais os homens expressaram a si próprios e o mundo".

A expressão vozes-mulheres em cena é uma expressão que sugere mais que a expressão vocal ou a passagem desta para a escrita. Pois, sua utilização se inscreve como uma metáfora para a representação através da "maneira se- 
mântico-social depositada na palavra" (BAKHTIN, 2010, p. 65). Assim, as vozes-mulheres falam de si e de tantas outras como formas de inscreverem-se no mundo. Para Bubnova, Barronas e Tonelli (2011, p. 272) a voz está circunscrita como "fonte de um sentido personalizado; atrás dela há um sujeito pessoa [...] que vai sendo modificado no tempo ao ser retomado por outros participantes no diálogo".

Na perspectiva da linguagem, a mulher resiste inicialmente pela oralidade, através dos ensinamentos, canções de ninar, histórias contadas aos filhos e fiIhas e, posteriormente, se colocando também na escrita. A linguagem é a forma articulada que utilizamos para refletir e representar todos os universos possíveis, sejam eles individuais ou coletivos. O "objeto em que se inscreve o poder, desde toda eternidade humana, é: a linguagem - ou, para ser mais preciso, sua expressão obrigatória: a língua" (BARTHES, 2013, p. 65). Para o teórico, a linguagem é a forma de maior poder. Ela nos dá acesso aos mundos sociais, aciona mecanismos relacionais que necessitamos e está sempre à serviço de algo ou alguém.

Assim, não se pode passar despercebida ou ingenuamente por nenhuma forma de manifestação da linguagem. E, quando esta linguagem é acessada pelas mulheres, já silenciadas por tanto tempo, essa forma de poder precisa ser vista e analisada em todos os seus vieses. Para esse texto, realizamos um recorte de escrita feminina no jornal porto-alegrense $O$ Exemplo, no início do século $X^{2}$. Um jornal que já nasce à serviço de causas sociais, fundado por jovens negros, e posteriormente abre-se para receber as escritas de mulheres, negras ou não ${ }^{3}$. E, apesar de não haver nas publicações relatos sobre este aspecto, possivelmente as mulheres negras tenham participado ativamente dessas publicações ou acessado a esse impresso. Isso porque o mesmo realizava anúncios de produtos voltados aos afazeres domésticos, abordava conteúdos relativos a como educar e a saúde dos filhos.

2 A apreciação do conteúdo dos poemas do jornal O Exemplo partiu de um corpus delimitado, situado entre 1902 a 1927, textos a que conseguimos ter acesso, dado o desafio de recuperação, ou mesmo, dado em virtude das interrupções anunciadas pelos editores de $O$ Exemplo.

3 Sobre a origem do jornal O Exemplo em Porto Alegre (RS), seus editore e colaboradores, bem como sua relevância para a época, consultar Sousa (2019). 
O jornal O Exemplo surgiu no campo da imprensa com a intenção de propagar discursos que oportunizassem o levantamento moral e intelectual da população de cor. Para efetivar esse propósito, ele afirma que seu programa reside na defesa da classe e do aperfeiçoamento de seus conhecimentos. Assim, O Exemplo sugere uma diversidade de questões, mas uma sobressaí: ser um exemplo para seus leitores. Isso porque, esse impresso é dirigido por um grupo editorial majoritariamente negro, pelo menos em suas primeiras fases (SOUSA, 2019, 2020).

Nessa direção, Pinto (2006) inscreve o jornal O Exemplo como "Imprensa Negra", pois discute os interesses da população negra brasileira, como o combate ao racismo, à discriminação e ao preconceito racial. Para atingir esse propósito, a "imprensa negra" enfrentou as barreiras impostas pela "imprensa branca", que continuava a postular a servidão da população negra, insensível aos anseios e às reivindicações das comunidades negras. Nesse sentido, o jornal O Exemplo contou com a contribuição de textos de algumas mulheres interessadas pela causa negra que se fizeram presentes a partir de gêneros textuais como a poesia. Assim, para apreciação e apresentação desse corpus empírico, selecionamos oito poesias. As temáticas variam e estão situados historicamente. Ou seja, em diferentes momentos históricos, a vozes-mulheres se fazem presentes no jornal O Exemplo. Pois, estamos nos referindo àquelas que romperam, em parte, com os espaços predefinidos historicamente, com uma visão de que o sexo masculino "vale mais", ao mesmo tempo, como protagonistas de uma história de vozes-muIheres negras ou não negras atenta às transformações políticas e culturais de uma época.

\section{A ESCRITA DE VOZES-MULHERES EM O EXEMPLO}

Nesse texto procuramos, então, evidenciar às produções de autoria feminina inscritas no jornal $O$ Exemplo. Essa produção é fruto direto do movimento de mulheres de um tempo histórico que empreenderam esforços no sentido de desconstruir os mitos de sua inferioridade e incapacidade. Essa presença das 
vozes-mulheres nas páginas deste impresso e de tantos outros no país discute sobre suas histórias de vida e de seu papel na sociedade.

Apontaremos apenas características mais gerais no intuito de situar nosso leitor quanto ao conteúdo abordado nos poemas, sem a ambição de realizar uma crítica completa de cada um, dado o formato deste texto. Os traços que destacamos são alguns que mais se sobressaem, dado o contexto histórico, social e literário da época. O primeiro poema, intitulado "Soberano", nos remete à relação com o sistema econômico vigente - o capitalismo.

\section{Soberano}

\section{$(\ldots)$}

Para mim a sociedade

Se abre de par em par, -

E possuindo-me um infame

Faz-se logo a titular.

Todo o belo o elegante

No meu porte se encerra,

Existem pra mim palácios

Debaixo de mar e terra! -

Sou o maior andarilho;

Tenho do mundo, potência:

- encerro a sabedoria,

- encerro a experiência!

- Mas que és? Grita a ciência,

- Quem és tu, ó desordeiro?!

Sou o rei do mundo!

Caluda! Sou o dinheiro - 
Uma Democrata (O EXEMPLO, 19 de dez. 1902)

Nele, o eu poético reflete sobre o dinheiro que é a voz colocada nos versos afirmando, na última estrofe, ser "o dono do mundo". Essa é uma reflexão importante se considerarmos que, finda a escravidão, negros e negras acessam este sistema e, são nele inseridos bruscamente, estando à margem do espaço de mão de obra remunerada, ao mesmo passo que necessitam lutar pela subsistência. Para as mulheres, a situação era ainda mais precária, dados os índices de analfabetismo e da existência do impedimento legal para a participação da vida pública, conforme consta no censo de 1872. A esse respeito, Davis (2016, p. 23) aborda que "depois de um quarto de século de "liberdade", um grande número de mulheres negras ainda trabalhava no campo. Aquelas que conseguiram ir para a casa-grande encontraram a porta trancada para novas oportunidades". Ainda segundo a autora (2016, p. 23), um quantitativo "infinitesimal de mulheres negras conseguiu escapar do campo, da cozinha ou da lavanderia".

O panorama apresentado por Davis sugere pensar em um outro aspecto a ser considerado no poema "Soberano", é o uso do pseudônimo "Uma Democrata" para assinalar a autoria do texto. Essa era uma prática muito comum nesta época (1902) e segue-se por muitos anos. Como as mulheres ainda eram "tuteladas" pelo pai ou pelo marido, não tinham direito à participação na vida pública. Dessa forma, o sistema patriarcal e capitalista tentou silenciá-las, no entanto, as vozes-mulheres apareciam, mesmo que timidamente com o uso de pseudônimo.

O poema "O coveiro", de Rosália Sandoval (1909) traz uma visão sobre este ofício penoso de despedir-se da própria filha, parte de si mesmo. O coveiro padece de dois sofrimentos, o da profissão e o de agora ter que se despedir de sua descendente. E pensando-se no contexto da época, cabe a hipótese de termos aqui uma metáfora para a vida das mulheres e homens que amargavam em ofícios árduos, ainda em trabalhos análogos à escravidão, e que, por muitas vezes, submetiam-se às condições das mais degradantes para conseguir seu sustento. 


\section{O Coveiro}

Todas as tardes na hora do sol posto,

Qual um bando de alados prazenteiro,

Os operários de tostado rosto

lam beber à venda do sineiro.

De um balcão velho no sebento encosto

Debruçava-se alegre e alvissareiro

O grupo... colibris em mês de agosto...

E quem mais gargalhava era o coveiro!

Mas hoje ele voltou triste absorto

Ai! Quanto pranto o seu olhar contém!

Como que trouxe o coração já morto!

Quantos mortos deixou naquela trilha

E voltava a sorrir... hoje, porém,

Chorou por todos ao enterrar a filha!

Rosália Sondoval (O EXEMPLO, 19 de dezembro de 1909)

Em "O confessionário", de Celia D’Ambrosio, há nos versos - Ajoelhada, qual uma criminosa, I Ao pé do negro altar de penitências - uma crítica ao viés religioso que usa das punições para levar à redenção. Por isso é que a redenção vem apenas depois dos pecados e pelos caminhos tortuosos pelos quais temos de passar. Seguem-se os versos Ver Jesus genuflexo ante Nero, I A inocência ajoelhada aos pés do Crime! - Sagrado e profano simbolizados pelos ícones do cristianismo e do personagem histórico a quem o caráter de maldade é atribuído. 


\section{O Confessionário}

Ei-la a donzela cândida e formosa,

Cheia de timidez e de inocência,

Ajoelhada, qual uma criminosa, Ao pé do negro altar de penitências...

Aquela alma inocente, cor-de-rosa,

Só purifica diante da impudência! -

Eia a aurora sublime, esplendorosa,

Pedindo à noite brilho e aurifulgência!

Mas que quadro estupendo, extraordinário:

Um anjo puro, singular, sincero,

Confessando-se a um demo sanguinário!

Ver Jesus genuflexo ante Nero,

A inocência ajoelhada aos pés do Crime!

Celia D'Ambrosio (O EXEMPLO, 6 de mar. 1910)

Nos versos do poema "Outrora e hoje", de Marcia Sampaio de Andrade (1917), desde a primeira estrofe percebemos a presença da dualidade entre bem e mal - a antítese que guia a vida e a luta de homens e mulheres negros ou não há a presença de marcas que sinalizam o amor romântico e a religiosidade cristã. 


\section{Outrora e hoje}

Outrora quando a lâmina maldita

Dos maus, dos inconscientes, dos tiranos,

Ameaçava aniquilar precita

Nossa ventura no verdor dos anos,

Presença da dualidade entre bem e mal

A antítese que guia a luta.

Quando a mão desses entes desumanos

A haurir nos dava o cálix da desdita,

Quanta amargura... quantos desenganos

Sofremos, meu amor?! Dor inaudita!

Hoje, em troca um perdão lhes mandaremos,

Hoje que nos uniu o Ser Divino,

E que a Glória nos coube e que vencemos!

Deus que é grande e que é santo, Deus que é puro,

Não podia afastar nossos destinos,

Turbando de uma vez nosso futuro!

Marcas que sinalizam o amor romântico e a religiosidade cristã

Marcia Sampaio de Andrade (O EXEMPLO, 13 de maio. 1917)

Em 13 de Maio, um registro da luta pela libertação do povo negro é apresentado. A data de 13 de maio foi instaurada como marco pelo fim da escravatura. No entanto, no ano da publicação do poema, ainda existiam, como se seguiram por muitos anos, focos de escravidão por todo o país. Aqui ainda se 
apresenta uma visão ingênua de que a princesa Isabel tenha sido "a redentora", o que mostra que a consciência político e social no poema ainda se mostra limitada quanto a esse viés.

\author{
13 de Maio \\ Treze de Maio! Esplendoroso dia \\ Em que surgiu a lei libertadora! \\ Neste nosso Brasil, já não podia \\ Existir uma raça sofredora!
}

Aquela escravatura enegrecia

A nossa história tão encantadora!

Treze de Maio! Dele se irradia

O nome de Izabel - a Redentora!

Foi a nossa princesa derradeira

Que espalhou pela Pátria brasileira

O sentimento de fraternidade!

Treze de Maio! Venturosa data

Em que um novo horizonte se desata

No gesto da princesa da Bondade

Lola de Oliveira (O EXEMPLO, 13 de maio. 1923)

O amor romântico, porém, com alguns traços de desconstrução da idealização amorosa, aparece no poema "Incertezas", de Paula Ferreira (1925). Na última estrofe - Quem o pode saber? Do amor a esfinge \É impenetrável, que a mulher de gelo Wão mostra nunca quando é que ama ou finge - a mulher não se 
inscreve como a amada idealizada e à espera de seu amado. Longe disso, mas aquela que pode até não demonstrar sentimentos ou mesmo fingir que sente. Aqui a mulher já é representada como sujeito atuante e detentora de sua voz e suas ações, bem diferente da mulher caracterizada em outros momentos pela literatura brasileira.

\section{Incerteza}

De um velho amigo uma saudosa carta Ontem me veio às mãos, recém-escrita.

Nela me conta com linguagem farta Uma história de amor longa e maldita.

Dessa que amou uma ideia não se aparta Uma angústia mortal suprema e aflita. Ele amou... e foi amado, amando Marta, Essa que o fez sofrer dor infinita.

Ele amou, sem saber, e, torturado, Vive a sofrer, num negro pesadelo, Por não saber se amou e foi amado.

Quem o pode saber? Do amor a esfinge É impenetrável, que a mulher de gelo Não mostra nunca quando é que ama ou finge. Amor romântico, porém, com alguns traços de desconstrução da idealização amorosa.

Paula Ferreira (O EXEMPLO, 15 de fev. 1925) 
"A fechadura" é um dos mais herméticos poemas localizados. Carregado de metáforas e subjetividade nos permite apreciá-lo por mais de um prisma. Nesse sentido, o texto nos convida a refletir as vozes-mulheres e o contexto de fundação e veiculação do jornal $O$ Exemplo.

\author{
A fechadura \\ Assimétrica e feia e gasta e enferrujada, \\ Com quatro pregos presa à velha porta escura, \\ A um canto imundo jaz a pobre fechadura, \\ Qual traste objeto e vil, inerte, abandonado. \\ E nesta gelidez do ouvido conjectura \\ - o quê? - nem ela mesmo o sabe, a infortunada! \\ Talvez que os dias bons relembre, e os de ventura, \\ De glória e de esplendor numa porta doirada. \\ E parece chorar! E esse imenso estoicismo \\ É irmão da dor oculta e irmão da desventura \\ De muitos corações depósitos pelo egoísmo
}

Figulinas (O EXEMPLO, 19 de abr. 1925)

A fechadura, objeto que geralmente é caracterizado como aquele que dá acesso, abertura às coisas e lugares, aqui é caracterizada como "assimétrica e feia e gasta e enferrujada”. Ela está abandonada, como se os acessos a que ela podia levar estivessem cercados de algum impeditivo. Mas há a memória dos dias de "glória e esplendor", ou seja, uma consciência, ainda que atrelada ao passado, de seus feitos. Esse estado de letargia e momento nostálgico pode nos levar a um viés das lutas enferrujadas, deixadas de lado, onde apenas no campo 
da memória se fazem presentes. E nos últimos versos, o lamento por esse momento sem as ações coletivas ou os acessos necessários, é trazido pelos versos "É irmão da dor oculta e irmão da desventural de muitos corações depósitos pelo egoísmo".

O último poema que trazemos é "Uma vida", de Ana Amélia Q. C. de Mendonça (1927). Nele, o eu poético traz a efemeridade da vida como temática central. Nele, as vozes são lançadas como forma de estar no mundo. Nos versos minhas canções espalho e ergo meus ais", retomamos o conceito da linguagem como forma de poder, de Barthes. No entanto, há um certo conformismo diante das situações da vida no verso "nada ambiciono, como em nada creio". Nesse ceticismo que beira a desistência, somente o amor e os versos contam como jornada e bagagem para a partida. O eu poético apresenta sua condição de "ser" que passa pelo mundo sem deixar legados.

\section{Uma vida}

Passo no mundo como tudo passa,

Que todos os destinos são iguais.

Vida! És igual à nuvem de fumaça, Que depressa se esvai, como te esvais...

Como os outros, eu sirvo a minha taça,

Em que há gotas amargas e fatais;

E entre o bem que promete e o mal que ameaça, Minhas canções espalho e ergo meus ais.

Nada ambiciono, como em nada creio,

Sei que no eterno ardor da eterna lida

Tudo continuará quando eu me for. 
Ódio não levarei dentro do seio,

Porque eu resumo toda a minha vida

Em uns pobres versos e num grande amor.

Ana Amélia Q. C. de Mendonça (O EXEMPLO, 20 de mar. 1927)

Nos poemas selecionados, percebemos a variedade de temáticas elencadas. Os versos, geralmente ainda seguem um esquema de rimas simples e alguns a estrutura dos sonetos clássicos (dois quartetos e dois tercetos), embora outros já apresentem uma mudança nessa forma. Não entraremos aqui no mérito de situar esses poemas em escolas literárias, embora seja um ponto relevante, nos interessa mais a presença dessas mulheres na escrita que qualquer rótulo situacional.

A escolha do gênero poesia também não é aleatório. Para Pignatari (2014), o poema é um ser de linguagem. O poeta faz linguagem fazendo poema. Logo, ele está sempre criando e recriando a linguagem. Dito de outra forma, o poeta está sempre criando o mundo. $E$ as vozes-mulheres trazidas nesses poemas recriam, de acordo com Bakhtin (2006), o mundo de suas vivências e observâncias. E, é pelo olhar dessas mulheres, precursoras no ofício de poetas no jornal O Exemplo, que essas vozes se assumem e se tornam vozes sociais. Em um tom sereno e comprometido com essa perspectiva o jornal O Exemplo, em 17 de dez. 1928, afirma que "O homem ou a mulher verdadeiramente bem-educados tratam a todos do mesmo modo, sem distinção de posição ou de classe".

Essas mulheres rompem com as expectativas, até mesmo com as exigências que lhes eram imputadas. "A mulher perfeita era retratada na imprensa, na nova literatura popular e até nos tribunais como a mãe perfeita. Seu lugar era em casa - nunca, é claro, na esfera política" (DAVIS, 2016). Longe da figura de "mulher perfeita" imposta pela sociedade patriarcal, as poetas aqui apresentadas fazem da linguagem seus objetos de poder e lançam, não apenas vozes, mais corpos, ideias, palavras-sensações ao mundo pelo instrumento do jornal que the abria nesse momento as portas para que pudessem se fazer presentes. 


\section{CONSIDERAÇÕES}

Para tecer algumas considerações a respeito de como comparece a escrita feminina no jornal O Exemplo, ou seja, de como se inscrevem as vozes-mulheres em cena como práticas de escrita não tuteladas, nos propusemos partir da linguagem e identificamos as vozes-mulheres que constroem discursos. Sobre isso o texto nos indica que as vozes-mulheres não falam somente de si, mas de toda uma comunidade ao seu redor. É somente por meio da possibilidade de fazer ecoar sua voz que a mulher pode ser e estar de fato no mundo a partir da linguagem, seja falada ou escrita, meio pelo qual ela acessa o mundo e, dessa forma, se inscreve nos contextos individuais e sociais.

Assim, procuramos demonstrar que, ainda no início do século $\mathrm{XX}$, a escrita feminina começava a aparecer no jornal O Exemplo, fruto de vozes-mulheres que as antecederam, estas, não aceitaram permanecerem confinadas ao espaço privado e lutavam por seus direitos básicos como a presença e a participação na vida pública. Nesse sentido, é possível identificar o caráter potente e revolucionário deste jornal pela presença das vozes-mulheres.

Desse modo, se, por um lado, a literatura sobre as mulheres as colocou sob tutela dos pais ou maridos, sem possibilidade legal de liberdade na sociedade de forma atuante; por outro lado, as mulheres que escreveram no jornal O Exemplo se tornam, assim, junto a outras mulheres da época e, em outros contextos, precursoras do ofício da escrita feminina.

O corpus empírico selecionado sugere observarmos que a escrita feminina caminha por vários vieses, desconstruindo a visão equivocada de que a mulher só escrevia a partir de temas muito específicos à suas vivências "autorizadas" como o lar e a prole, ou ainda sobre o amor romântico, uma temática que, embora apareça em alguns textos, não é a temática predominante, como foi possível identificar.

Cabe assinalar que, a escrita feminina no gênero poema para o jornal $O$ Exemplo rompeu, em parte, com os espaços predefinidos historicamente para a 
mulher, ao mesmo tempo que as situam como protagonistas de uma história de vozes-mulheres atenta às transformações políticas, sociais, culturais e educacionais e, as situam em uma posição de resistência à opressão vivenciadas cotidianamente por aqueles que sempre realizaram esse ofício.

A inscrição do conteúdo dos poemas nos leva a depreender que as mulheres escreventes ao jornal $O$ Exemplo, teceram seus discursos, ainda que em condições extremamente adversas à época. Elas se uniram pelo poder da linguagem para se colocar no mundo. Pois, para elas, a linguagem, que muito passou pelo lugar da subserviência, agora toma seu lugar de poder. Esse poder é assumido e colocado à serviço de seus ideais e causas que defendiam.

Por fim, embora seja um recorte histórico documental, o texto nos traz a riqueza das muitas vozes-mulheres que se levantaram no jornal $O$ Exemplo e nos dão uma direção para pesquisas futuras neste sentido, como a análise biográfica dessas mulheres. Das vozes que se assomaram, através de muitas formas de comunicação e, com o crescimento da imprensa no Brasil. A materialidade do poder da linguagem do qual nos rememora Barthes (2013, p. 15), está presente em todos os textos, do poder dizer e do que o texto "nos obriga a dizer".

\section{REFERÊNCIAS}

BAKHTIN, M. Estética da criação verbal. Trad. Paulo Bezerra. São Paulo: Martins Fontes, 2006.

BAKHTIN, M. Os gêneros do discurso. In: BAKHTIN, M. Estética da criação verbal. Trad. Paulo Bezerra. 4ed. São Paulo: Martins Fontes, 2010.

BARTHES, Roland. Aula inaugural da cadeira de semiologia literária do Colégio da França. São Paulo: Cultrix, 2013.

BUBNOVA, Tatiana; BARONAS, Roberto Leiser; TONELLI, Fernanda. Voz, sentido e diálogo em Bakhtin. Rev. Estud. Discurso. Vol. 6, №. 1. São Paulo.Aug./ Dec. 2011.

CERTEAU, Michel de. A invenção do cotidiano. 1 Artes de fazer. Petrópolis, Vozes, 2014. 
DAVIS, Angela. Mulheres, raça e classe. São Paulo: Boitempo, 2016.

JORNAL O EXEMPLO, 1920-1930. Disponível em: http://ihgrgs.org.br/hemeroteca.html

Acesso em: 13 de jan. 2020.

JORNAL O EXEMPLO, 1892-1919. Disponível em: http://culturadigital.br/jornaloexemplo/. Acesso em: 13 de jan. 2020.

MURARO, Rose Marie. A mulher no terceiro milênio: uma história da mulher através dos tempos e suas perspectivas para o futuro. Rio de Janeiro: Rosa dos Tempos, 2002.

PESAVENTO, Sandra Jatahy. História e história cultural. 2 ed. Belo Horizonte: Autêntica, 2008.

PIGNATARI, Décio. O que é comunicação poética. $10^{\circ}$ edição. São Paulo. Ateliê Editorial. 2014.

PINTO, Ana Flávia Magalhães. De pele escura e tinta preta: a imprensa negra do século XIX (1833-1899). UNB, 2006, 197 f. Dissertação (Mestrado em História) PPG em História, Instituto de Ciências Humanas, UNB, Brasília, 2006.

SOUSA, Ricardo Costa de. Levantamento moral e intelectual dos homens de cor: o caso do jornal O Exemplo, Porto Alegre, RS (1892-1905). Via Atlântica, (37), 2020.

SOUSA, Ricardo Costa de. Instrução e circulação da palavra escrita: o caso do jornal O Exemplo (Porto Alegre, RS, 1892-1930). Porto Alegre, 2019, 241f. Tese (Doutorado em Educação). Universidade Federal do Rio Grande do Sul, Faculdade de Educação, Programa de Pós-Graduação em Educação, Porto Alegre, 2019. 
dol $10.48209 / 978-65-89949-16-2$

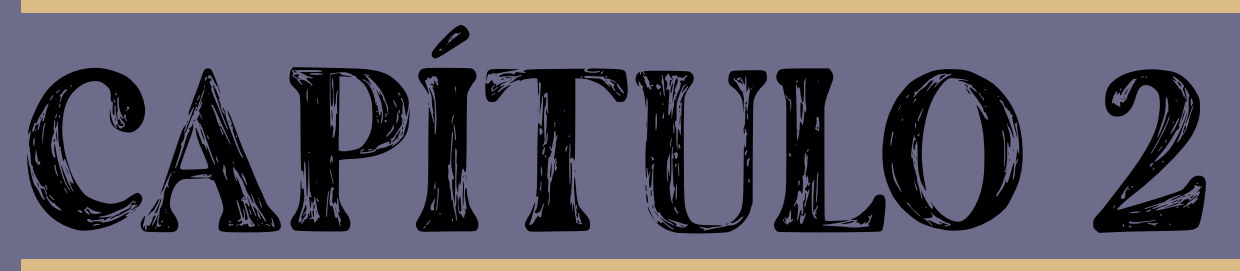

\section{ESTUDO DO CONTO NINHO DE PERIQUITOS DE HUGO DE CARVALHO RAMOS: UMA EXPERIÊNCIA LITERÁRIA COM ESTUDANTES DO $4^{\circ}$ ANO DO ENSINO FUNDAAMENTA A L}

Rodrigo Milhomem de Moura Ruskaia Fernandes Mendonça Alexandre Ferreira da Costa

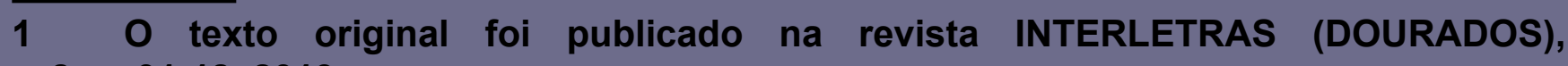
v. 8, p. 01-18, 2019. 


\section{INTRODUÇÃO}

Neste texto, temos o objetivo de discutir o uso das histórias em quadrinhos (HQ) como recurso didático para desenvolvimento da leitura e do letramento literário. As atividades foram realizadas no âmbito do Projeto Ponto de Apoio do Centro de Ensino e Pesquisa Aplicada à Educação da UFG. Para tanto, realizamos uma discussão acerca do gênero história em quadrinhos e do letramento literário. Em seguida, apresentamos a atividade desenvolvida com os alunos do $4^{\circ}$ ano do Ensino Fundamental I: uma recontagem de um conto tradicional da literatura goiana, Ninho de Periquitos, de Hugo de Carvalho Ramos, em formato de história em quadrinhos.

O trabalho surgiu a partir de algumas discussões em sala de aula e com colegas da Língua Portuguesa sobre o uso de quadrinhos. Outro fator que nos levou a escrevê-lo foi o interesse que as crianças têm por esse gênero. Assim, entendemos que a temática deve ser explorada, com vistas à criação de atividades que podem contribuir para a formação histórico-social dos/as estudantes, bem como seu uso para o desenvolvimento da leitura, da escrita e das esferas artístico-literárias. Destacamos que as atividades desenvolvidas estão ancoradas na perspectiva histórico-cultural e discursiva, fundamentadas a partir de conceitos vigotskianos e bakhtinianos.

Partindo de tais discussões, traçamos como perguntas: de que maneiras os quadrinhos podem fornecer subsídios ao letramento literário e como podem contribuir para o desenvolvimento da leitura e da escrita? Acreditamos que os quadrinhos podem influenciar os/as educandos/as a desenvolverem o gosto pela leitura literária, concomitantemente, podem ajudá-los/as a constituir um processo de apreciação ética e estética da literatura.

\section{AS HISTÓRIAS EM QUADRINHOS COMO GÊNEROS DISCURSIVOS: UM BREVE ESBOÇO HISTÓRICO}

Ao concebermos as histórias em quadrinhos (doravante $H Q$ ) como gêneros discursivos, corroboramos os ideais de Bakhtin (2003), que demonstram a 
grande variedade de gêneros discursivos existentes. Isso porque, "[...] a variedade virtual da atividade humana é inesgotável, e cada esfera dessa atividade comporta um repertório de gêneros do discurso que vai diferenciando-se e ampliando-se à medida que a própria esfera se desenvolve e fica mais complexa" (BAHKHTIN, 2003, p. 280). Por este ângulo, as HQ não são gêneros recentes, pois permearam diversas sociedades respondendo a anseios e necessidades sociais de cada momento histórico.

Vergueiro (2010, p. 9), por exemplo, comenta que o homem das cavernas "gravava duas imagens, uma dele mesmo, sozinho, e outra incluindo um animal abatido, poderia estar na realidade, vangloriando-se por uma caçada vitoriosa, mas também registrando a primeira história contada por uma sucessão de imagens". Esse processo de "contar" por meio de imagens ainda é um dos mecanismos mais utilizados em nosso tempo, em especial, pelas crianças. E "tanto o homem das cavernas como a criança de hoje parecem ter compreendido que, como diz a sabedoria popular, uma imagem fala mais do que mil palavras" (VERGUEIRO, 2010, p. 9, grifo do autor). Se uma imagem fala mais que mil palavras, pode ainda suscitar novas significações quando aliada à escrita. Neste sentido, para Bakhtin (2016) os gêneros são relativamente estáveis e estão a serviço de um dado campo da atividade humana. À vista disso, eles acabam sofrendo alteração ao longo dos tempos para se adequar às demandas sociais e, por vezes, transformam-se em novos gêneros ou ganham novas incrementos à sua estrutura.

O surgimento da imprensa e a evolução da indústria tipográfica foram de grande valia para a constituição e o aparecimento das HQ como gêneros produzidos em larga escala, uma vez que passaram a ser um meio de comunicação de massa, com constantes publicações em jornais (VERGUEIRO, 2010). Cabe insistir, portanto, que "observa-se que o repertório de gêneros de cada esfera da atividade humana vai diferenciando-se e ampliando-se à medida que a própria esfera se desenvolve e fica mais complexa" (FARACO, 2009, p. 127).

Para Bakhtin (2006), todo signo é ideológico, não existe enunciado não 
ideológico. Nesta lógica, ao analisar o contexto de 'explosão' das HQ poderemos tentar compreender o porquê de terem sido censuradas durante uma época. Após a Segunda Guerra os quadrinhos chegaram ao ápice: histórias de guerra, conflitos bélicos, história de suspense, terror, o cunho mais realista da sociedade, e vários outros fatores se multiplicaram.

Assim, segundo Vergueiro (2010), após o advento da Segunda Guerra e início da Guerra Fria surgiu um ambiente de desconfiança em relação aos quadrinhos, pois um psiquiatra alemão, radicado nos Estados Unidos, Fredric Wertham, encontrou campo privilegiado para os pretensos malefícios das histórias em quadrinhos e as denunciou, inferindo que elas seriam uma grande ameaça aos jovens; era contrário ao conteúdo de grande parte dos quadrinhos e por isso usou casos específicos de alguns de seus pacientes para comprovar sua tese. Uma das defesas usadas pelo alemão era a de que algumas leituras, inclusive a do Batman, podia levar os jovens ao homossexualismo. As críticas se espalharam por alguns países e o teor delas, embora menos severo, retratava práticas similares. No Brasil, por exemplo, foi criado um Código de Ética dos Quadrinhos - censurando o uso dos gêneros.

\section{HISTÓRIAS EM QUADRINHOS: UMA FORMA DE LETRAMENTO LITERÁRIO?}

Discutir sobre o letramento literário requer pensar em primeira instância sobre o letramento em sua contextualização geral. Interessa-nos questionar, dessa maneira, o que é letramento e para que serve. Magda Soares é uma das autoras pioneiras em discussões sobre esse tema no Brasil. Para ela, " letramento não é pura e simplesmente um conjunto de habilidades individuais; é o conjunto de práticas sociais ligadas à leitura e à escrita em que os indivíduos se envolvem em seu contexto social" (SOARES, 2000, p. 72). Portanto, o letramento é a aplicação da leitura e da escrita em âmbitos sociais, diante das diversas tarefas cotidianas e serve para orientá-las e ajudar em suas execuções. Ou, ainda, as práticas de letramento são também constitutivas dessas circunstâncias sociais. 
Acreditamos que letramento literário é um desdobramento do letramento propriamente dito, isto posto, observa-se que o acesso às manifestações artísticas é de grande valia à formação histórico-social e artística dos indivíduos, daí inferimos a importância do acesso à literatura e sua prática em sociedade como forma de intervenção e mudança social. Segundo Cosson (2009):

[...] o letramento literário precisa acompanhar, por um lado, as três etapas do processo de leitura, por outro, o saber literário. No caso desse último, convêm ter na mente a distinção feita por M. A. Halliday em relação à aprendizagem da linguagem: a aprendizagem da literatura que consiste fundamentalmente em experienciar o mundo por meio da palavra; a aprendizagem sobre a literatura, que envolve conhecimento de saberes e as habilidades que a prática de literatura proporciona aos seus usuários [...]. (COSSON, 2009, p. 47).

Em consonância com a exposição do citado autor, podemos observar o papel do letramento literário e o papel da escola na formação educacional e social dos estudantes. Tendo em vista que o trabalho com a literatura na escola tradicional envolve normalmente a história da literatura e as características dos períodos ou momentos literários; e muitas esquecem-se de 'letrar' o/a aluno/a para a apreciação estética das obras; ajudá-los/as a ter uma percepção artística mais aflorada e desenvolver o gosto pela arte se faz necessário. Neste sentido, comungamos do posicionamento de Cândido (1995, p. 235) quando este afirma que "a função da literatura está ligada a complexidade de sua natureza, que explica inclusive o papel contraditório, mas humanizador (talvez humanizador porque é contraditório)". Acreditamos, assim como o citado autor, que a literatura tem o papel humanizador: de transformar 'em gente' quem tem acesso a ela. Por isso, essa arte deveria estar acessível a todos; deveria ser um direito humano. Isto é,

[...] focalizar a literatura com os direitos humanos em dois ângulos diferentes. Primeiro, verifiquei que a literatura corresponde a uma necessidade universal que deve ser satisfeita sob pena de mutilar a personalidade, porque pelo fato de dar forma aos sentimentos e à visão do mundo ela nos organiza, nos liberta do caos e portanto, nos humaniza. Negar a fruição da literatura é mutilar a nossa humanidade. Em segundo lugar, a literatura pode ser um instrumento consciente de desmascaramento, pelo fato de focalizar as situações de restrições dos direitos, ou de negação deles, como a miséria, a servidão, a mutilação espiritual. Tanto num nível quanto no outro ela tem muito a ver com luta pelos direitos. (CANDIDO, 1995, p. 239-240). 
Na literatura e pela literatura há luta, há resistência, há humanização, há respeito e há justiça social. A literatura, arte pela palavra, tem essa capacidade de transformação e intervenção social. Assim, concordamos com Candido (1995) de que ela deveria ser um direito humano. Santos $(2015$, p. 26$)$ também se preocupa com o processo de aquisição literária e expressa que a concepção de literatura que se deve adotar é aquela que favoreça a "formação leitora, especialmente o acesso à leitura dos clássicos no meio escolar. Em uma perspectiva de letramento literário, o ensino de literatura deve sofrer mudanças importantes em seus aspectos didáticos, considerando a realidade que aponta". Fazer com que o/a estudante desenvolva a apreciação e percepção estética deveria ser o foco da escola; letrá-lo/a pela e para arte é necessário para que a nossa 'humanidade' não seja mutilada, e os quadrinhos podem contribuir nesse processo.

Partindo dessas perspectivas, recorremos à Base Nacional Comum Curricular (BNCC) a fim de observar de que modo o documento oficial trata do letramento literário, assim como de gêneros como as HQ. Na BNCC, a organização das práticas de linguagem está dividida em campos. Segundo o documento, isso foi feito como forma de contextualização do ensino. Há um campo denominado como artístico-literário. Nesse campo, o guia busca possibilitar aos/às estudantes ter contato com as manifestações artísticas em geral "de forma particular e especial, com a arte literária e de oferecer as condições para que se possa reconhecer, valorizar e fruir essas manifestações" (BRASIL, 2017, p. 136). Além disso, a BNCC expressa que os quadrinhos são gêneros que podem ser trabalhados em sala de aula e expressa que em relação ao trabalho com as $\mathrm{HQ}$, pode-se "construir o sentido de histórias em quadrinhos e tirinhas, relacionando imagens e palavras e interpretando recursos gráficos (tipos de balões, de letras, onomatopeias)" (BRASIL, 2017, p. 95).

O Programa Nacional do Livro Didático - Literário (PNLD-2018 - Literário), em consonância com a BNCC, também reconhece que as $\mathrm{HQ}$ são gêneros importantes para o letramento literário. Dentre os gêneros a serem selecionados no PNLD-2018 está uma denominada 'Livro de imagens e história em quadri- 
nhos'. Dos livros sobre o referido gênero direcionado aos/às estudantes dos anos iniciais do ensino fundamental estão um total de oito obras, dentre elas: Ariano Suassuna em quadrinhos, Luiz Gonzaga em quadrinhos, Monteiro Lobato em quadrinhos e José Lins do Rêgo em quadrinhos. O que mais chama a atenção é a quantidade de livros em quadrinhos e imagens direcionados aos discentes do Ensino Médio - um total de 16 obras. Dentre elas estão obras como: Odisseia, Dom Casmurro, Grande sertão veredas, O peru de Natal, Missa do galo e o Diário de Anne Frank em quadrinhos. Acreditamos que isso vai ao encontro daquilo que Santos (2015) desenvolve em sua dissertação: o acesso às obras literárias clássicas pode ser dar por meio dos quadrinhos em um primeiro momento e pode influenciar o/a jovem a procurar a obra original.

Neste segmento, as várias características das $\mathrm{HQ}$ as fazem ser um gênero multimodal, suscitam um lugar de destaque para o incentivo dos/as estudantes ao letramento literário, bem como para ajudá-los/as a desenvolver o gosto pela leitura. Em virtude disso, pactuamos com a ideia apresentada por Santos (2015, p. 35) de que "a HQ é uma linguagem autônoma, que tem mecanismos próprios para se constituir como estrutura narrativa, mas que tem pontos comuns com a literatura, assim como outras linguagens, como o cinema e o teatro, por exemplo". O autor discorre ainda que algumas editoras estão investindo na reformulação e adaptação de clássicos literários para histórias em quadrinhos, segundo ele, "acredita-se que o acesso a esse meio expressivo - sua consequente valorização - podem estimular o interesse dos jovens leitores pelo contato com o texto original" (SANTOS, 2015, p. 55).

Essa prática de transformar um gênero em outro como forma de trabalho com a escrita já estava descrita nos Parâmetros Curriculares Nacionais de Língua Portuguesa para Ensino Fundamental (PCN Ensino Fundamental). De acordo com os PCN (BRASIL, 1998, p. 52), "transformar um gênero em outro: escrever um conto de mistério a partir de uma notícia policial e vice-versa; transformar uma entrevista em reportagem e vice-versa" pode ser uma importante ferramenta para o aprimoramento da escrita. Por esse motivo, o próximo tópico é direcio- 
nado às análises de produções de histórias quadrinhos de alunos do projeto de extensão Ponto de Apoio da Universidade Federal de Goiás, desenvolvido no CEPAE. Os estudantes fizeram uma $\mathrm{HQ}$ do conto "Ninho de periquitos", presente na obra Tropas e boiadas, do autor goiano Hugo de Carvalho Ramos. Buscamos, por meio das análises, demonstrar como as histórias em quadrinhos podem ser importantes ferramentas para o trabalho com a literatura e as diversas artes.

\section{CONTEXTUALIZAÇÃo DA PRODUÇÃo DAS HISTÓRIAS EM QUADRINHOS: PROJETO PONTO DE APOIO}

A proposta de trabalhar com as histórias em quadrinhos em uma das atividades do Projeto Ponto de Apoio surgiu mediante o interesse apresentado pelos/as educandos/as por esse gênero literário. As atividades, fundamentadas na perspectiva histórico-cultural, procuram desenvolver a apropriação de significados, formação de conceitos e estruturação de sentido. Assim, conforme orienta Vigostky (2001), para que haja a constituição dos processos de aprendizagem pauta-se a ação com mediadores, isto é, instrumentos que auxiliam o sujeito em seu desenvolvimento. Por esse fator, pensamos que as HQ são ferramentas que podem ajudar os/as discentes a desenvolver diversas habilidades e competências, tendo em conta a linguagem mista e a diversidade temática que pode ser abordada e discutida por meio desse gênero.

O projeto Ponto de Apoio é uma proposta pedagógica para os/as alunos que apresentam alguma dificuldade de rendimento escolar em alguma disciplina. Essa proposta vai ao encontro da determinação legal prevista na Lei de Diretrizes e Bases da Educação (LDB) n 9.394/96, que determina que: "os estabelecimentos de ensino, respeitadas as normas comuns e as do seu sistema de ensino, terão a incumbência de: $\mathrm{V}$ - promover meios para a recuperação de alunos de menor rendimento". As turmas e a idade dos/as alunos/as atendidos/as variam, embora tenha sido colocado o limite de 13 anos de idade em 2018. Participavam do projeto cerca de 12 estudantes do $4^{\circ}$ ano e para as análises deste trabalho foram selecionados duas $\mathrm{HQ}$. 
Na esteira dessa discussão, ressaltamos que durante o ano de 2018 o projeto esteve estruturado em três eixos: Linguagem, Formação de Conceitos e Raciocínio Lógico Matemático. As atividades aqui descritas compõem o Ponto de Apoio de Linguagem, que esteve composto por professores/as de Língua Portuguesa (LP) e Geografia, apresentando um caráter interdisciplinar. É necessário citar que normalmente os/as docentes trabalham em parceria. Assim, juntam-se duas grandes áreas e trabalham-se assuntos recorrentes em ambas. Todavia, as atividades de produção das $\mathrm{HQ}$, tomando por base o conto Ninho de periquitos, de Hugo de Carvalho Ramos, foram mediadas pela professora de LP.

O trabalho com a literatura goiana é um dos pontos de destaque do CEPAE, principalmente nos quartos anos do Ensino Fundamental. Dessa forma, durante o segundo semestre de 2018 foi proposta aos/às estudantes a temática: O sertão/cerrado na literatura goiana. A partir disso, propusemo-nos a estudar alguns autores que escrevem, ou apresentam em seus textos, elementos do Cerrado. A primeira leitura realizada foi o conto Ninho de periquitos, de Hugo de Carvalho Ramos. Esse conto está inserido no livro Tropas e boiadas, de 1917. Esta obra é considerada de grande relevância para a literatura goiana. À época de sua escrita o estado de Goiás estava passando por mudanças significativas em seu contexto histórico-social-econômico; a obra é bastante sensível aos elementos naturais do estado.

O conto apresenta uma variedade linguística bastante pertinente à época de sua escrita, por isso, não apresenta uma leitura fácil, sendo permeado por palavras desconhecidas pelas crianças. Em virtude disso, fizemos, inicialmente, algumas leituras coletivas, nas quais, pausadamente, discutimos acerca dos elementos apresentados na narrativa. Nesse primeiro dia as crianças apenas ilustraram a urutu do sertão - uma cobra que aparece na história, um dos elementos-chave da narrativa - da forma como imaginavam que ela poderia ser. $\mathrm{Na}$ semana seguinte fizemos a releitura do conto e em seguida pediu-se para que as crianças, conjuntamente, recontassem a história. Cada estudante ia complementando o outro com detalhes da história. Além das leituras realizadas, cada elemento que os alunos apontam auxiliam para que as crianças construam a história, uma vez que, conforme orienta Vigostky (2001), o desenvolvimento do 
pensamento passa do pensamento socializado para o individual. Discussões e práticas como as mencionadas contribuem para que as crianças possam, no momento da escrita, ter uma sequência lógica do texto.

Portanto, as discussões e recontos orais que são realizados quando trabaIhamos uma história objetivam melhorar o discurso oral e escrito. Por outro lado, quando trabalhamos a mudança de um gênero para outro, objetivamos que os discentes consigam vislumbrar outros horizontes e, no caso específico do estudo, além de prepará-los para o discurso escrito, vislumbramos Ihes proporcionar o acesso à literatura de caráter regionalista. Buscamos, no Ponto de Apoio, além da formação de conceitos em Língua Portuguesa e em Geografia, possibilitar que os discentes tivessem acesso a um letramento literário. Assim, eles podiam ser os/as autores/as e ilustradores/as, ao passo que conheciam clássicos da literatura goiana.

Pensando nisso, após o reconto de forma oral, foi entregue para as crianças uma folha em formato de quadrinhos com a proposta de que recontassem a história. Para tanto, deveriam ilustrar e contar a história a partir do que haviam entendido, entretanto, deveriam buscar uma proximidade com o conto original. Devido à grande proximidade que as crianças têm com esse gênero, pois costumam lê-lo bastante, a discussão sobre os elementos que o compõem foi tranquila. Orientamos ainda que deveriam manter os elementos principais da história, construir diálogos, bem como ilustrar o que é descrito no conto.

\section{DO CONTO PARA A HQ: UMA ANÁLISE HISTÓRICO-CULTURAL E DISCURSIVA}

O conto "Ninho de periquitos", do autor goiano Hugo de Carvalho Ramos, narra a história de um homem sertanejo em seu cotidiano, abordando elementos que auxiliam na composição de informações para o estudo do Cerrado. O autor descreve, com sua narrativa singular, a vida do homem sertanejo e procura valorizar o trabalho no campo, apresentando elementos caracterizantes da vida no sertão goiano no período descrito. 
A história inicia com a personagem principal, Domingos, chamado pelo autor em alguns momentos como 'caipira', 'matuto' e 'roceiro', deitado em sua rede tocando viola após ter se alimentado. O homem se levanta para observar o milharal que em breve terá que colher, quando, antes de sair para trabalhar, é interrompido por um pedido do filho Janjão: que ele não se esquecesse de trazer os periquitos. Os periquitos estavam dentro de uma casa abandonada de cupins. Após o trabalho na roça, o caipira que já ia para casa, lembra-se do pedido do filho e chega a cogitar não realizá-lo. Todavia, naquele dia a criança completava dez anos e, para não entristecê-la, o pai resolve pegar os periquitos.

Ao enfiar a mão no local onde os periquitos haviam feito o ninho o pai sente uma picada e retira a mão. Em seguida, uma cobra, a urutu do sertão sai do buraco e o homem já sabe o seu destino: a morte. "O matuto sentiu uma frialdade mortuária percorrendo-o ao longo da espinha. Era uma urutu, a terrível urutu do sertão, para a qual a mezinha doméstica nem a dos campos possuíam salvação. Perdido... completamente perdido... [...]" (RAMOS, 2006, p. 61). Sem vacilar o homem toma uma atitude e decide decepar sua mão, para que assim pudesse sobreviver. Após tal ato, o homem enrola o braço na camisola de algodão que rasgou com os dentes e sai do mato com uma postura altiva e corajosa, "[...] como um deus selvagem e triunfante" (RAMOS, 2006, p. 61).

O conto apresenta elementos típicos do cerrado goiano. A estética de sua obra está na simplicidade de observação do sertão goiano. Bosi (2006, p. 240), ao discorrer sobre a principal obra de Hugo de Carvalho Ramos, menciona que "[...] seus contos reunidos em Tropas e Boiadas, revelam plena aderência aos mais variados aspectos da natureza e da vida social goiana [...]". Diante disso, observamos que obras deste tipo têm muito a contribuir com a formação social e crítica dos alunos, já que somos seres culturais e sociais e a literatura tem muito a demonstrar sobre uma dada época, para além de seu caráter humanizador. Partindo de tais aspectos, selecionou-se para análise neste trabalho, duas $\mathrm{HQ}$ que atenderam aos parâmetros do gênero história em quadrinhos, assim como a ordenação e a sequenciação da narrativa. Entretanto, é necessário ressaltar 
que todos os alunos conseguiram produzir. Analisemos a primeira $\mathrm{HQ}$, Ninho de "Piriquitos".

Figura 1 - Ninho de periquitos em quadrinhos

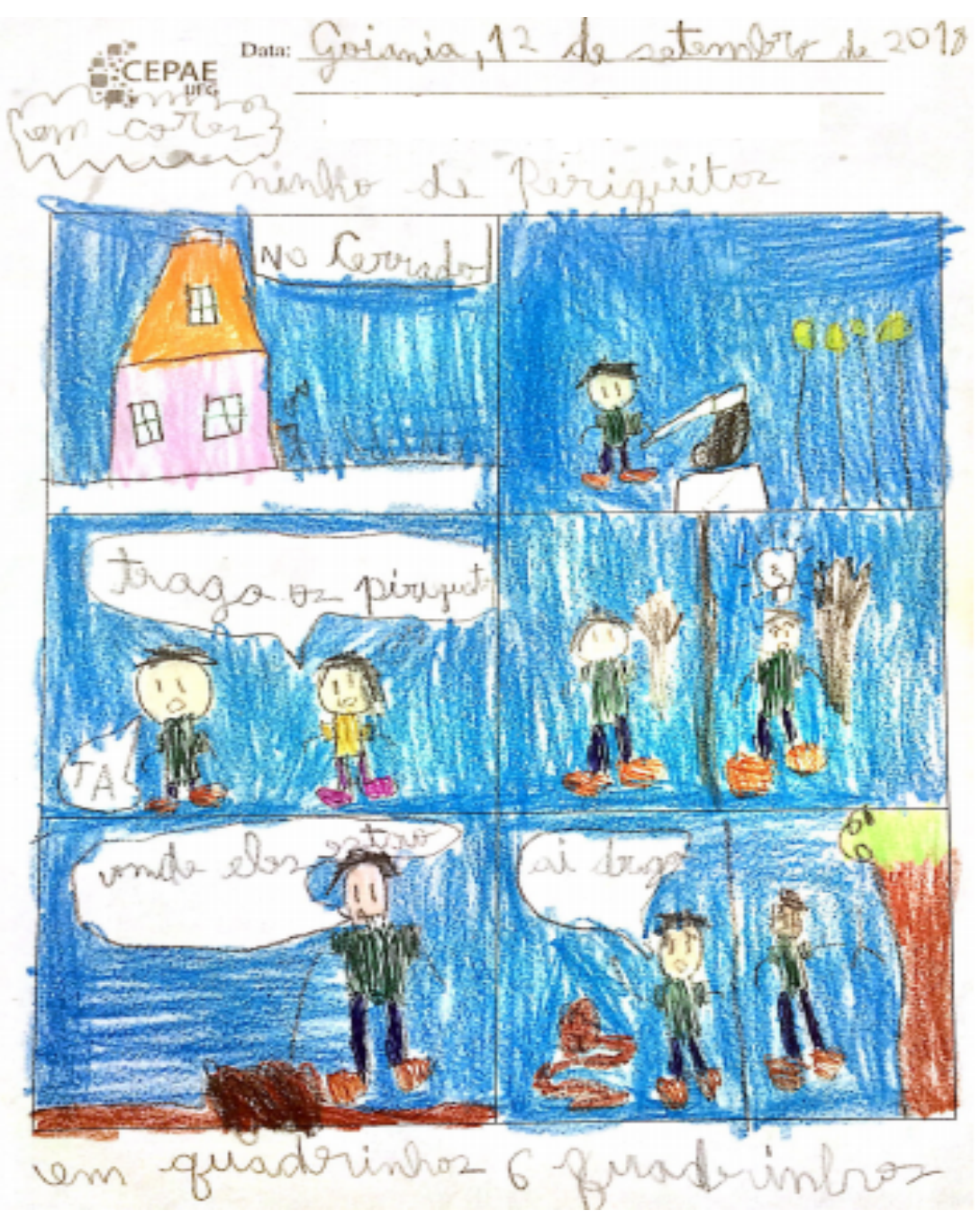

Fonte: Acervo dos autores e do CEPAE/UFG.

O aluno escolheu, como plano de fundo para sua $\mathrm{HQ}$, uma tonalidade de azul, desenhando ainda os espaços e a personagem principal. Ele consegue atender de forma sucinta ao proposto e sistematizar os elementos principais da narrativa. No primeiro quadrinho ele desenha uma casa e escreve "No Cerrado", podemos inferir que ele conseguiu entender o local em que se passa o conto. No segundo quadrinho, desenha a personagem principal, cortando lenha - trabalho típico do sertão goiano. Já o terceiro quadrinho é destinado ao diálogo entre pai e filho sobre o ninho de periquitos que há em um cupinzeiro. No quarto quadrinho o 'matuto' se desloca até o ninho; no quinto quadrinho ele parece procurar os bichi- 
nhos que, a esta altura, parecem ter virado lanche da urutu; no sexto quadrinho ele é picado e corta sua mão, pois o veneno da cobra é muito forte e pode mata-lo dentro de pouco tempo.

Figura 2 - HQ: Ninho de Periquitos
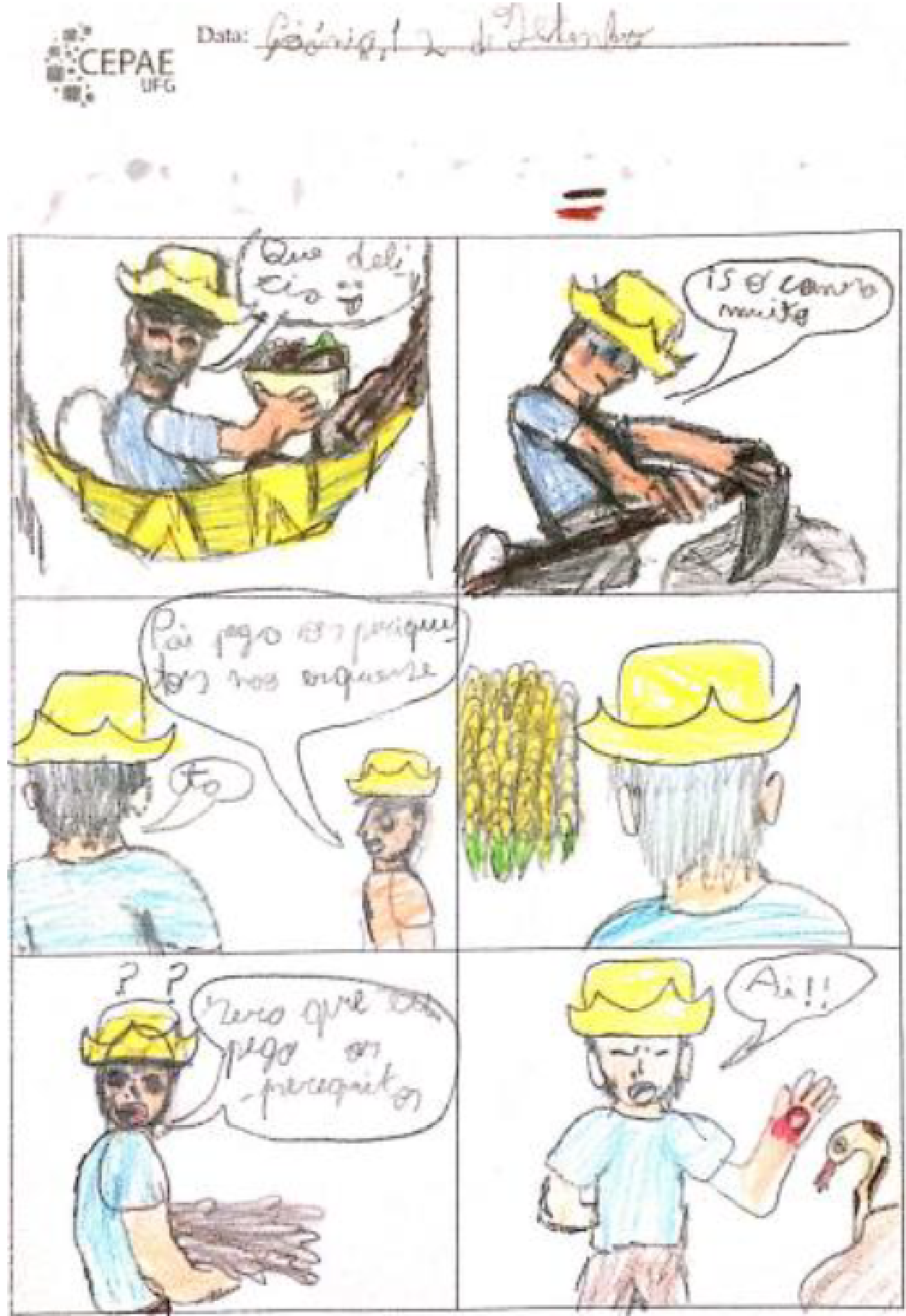

CAPÍTULO 2

Moura, R. M. de.; Mendonça, R. F.; Costa, A. F. da. ESTUDO DO CONTO "NINHO DE PERIQUITOS” DE HUGO DE 


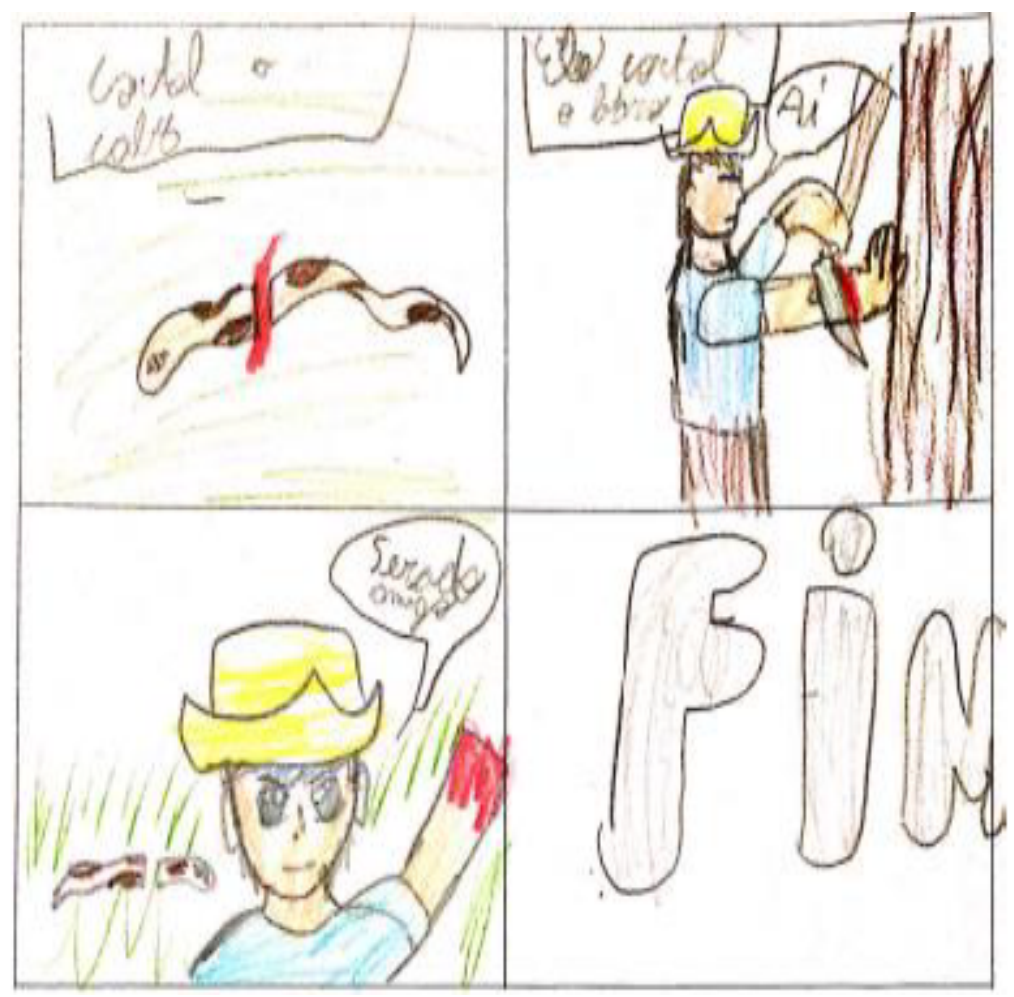

Fonte: Acervo dos autores e CEPAE/UFG.

Na segunda $\mathrm{HQ}$ percebemos alguns traços artísticos do discente, ele consegue se adequar à temática, assim como deixa transparecer uma qualidade bastante acentuada com os desenhos. Dessa forma, podemos observar que a narrativa está bastante concisa na HQ. No primeiro quadrinho o discente desenha o matuto na rede, deliciando-se com sua comida; no segundo, cortando lenha, ou seja, no trabalho; no terceiro estabelece o diálogo entre pai e filho, enfatizando o pedido do filho; no quarto quadrinho o pai observa o milharal; no quinto, voltando para casa, ele decide atender ao pedido do filho e vai até o ninho apanhá-los; no sexto, já no ninho, ele é picado pela cobra; no sétimo, ele demonstra que a cobra foi cortada ao meio pelo matuto; no oitavo, sabendo que o veneno da cobra é extremamente nocivo, decide cortar o braço; no nono o que mais chama a atenção é o semblante da personagem e seu braço cortado, como se fosse levantado como um troféu - parece um herói - e a urutu partida ao meio atrás dele; no décimo o aluno acrescenta o vocábulo: ‘fim', bem característico de algumas $\mathrm{HQ}$.

Observamos que, como o conto não é ilustrado, as crianças não tiveram nenhuma imagem prévia que as norteasse na elaboração dos desenhos, pautan- 
do essa atividade apenas nos elementos descritivos do texto e na imaginação. Vigotsky (2009) discute que a criatividade é um elemento que resulta da interação entre o indivíduo e a sociedade. Para o autor, a atividade de imaginar depende daquilo que é previamente apresentado e das experiências as quais o sujeito foi exposto. Assim, criar algo, caracteriza-se por dar destaque a algumas informações em detrimento de outras, procurando, dessa maneira, a formação dos conceitos. Corroborando esse posicionamento, Faraco (2009, p. 111) expressa que "[...] o que é dito (o todo do enunciado) está sempre relacionado ao tipo de atividade em que os participantes estão envolvidos". Isso é de fundamental importância para a constituição de uma identidade literária e para a própria apreciação estética das obras. Além do mais, quando os discentes estão envolvidos neste processo de criação eles acabam desenvolvendo uma série de habilidades e competências, sejam leitoras, de escrita, literárias e artísticas de uma maneira geral por meio do gênero.

Além disso, a partir das $\mathrm{HQ}$ podemos pensar em um ensino baseado na estilística. Dessa forma, não se valorizariam apenas os aspectos gramaticais ou imagéticos, mas o próprio estilo e a estrutura composicional do gênero, sempre pensando em uma concepção dialógica (BAKHTIN, 2013). Isto é, “[...] onde há estilo há gênero. A passagem do estilo de um gênero para outro não modifica o caráter do estilo nas condições que não lhe é próprio como também destrói e renova tal gênero." (BAKHTIN, 2016, p .21).

Neste sentido, no processo de criação artística as crianças deveriam imaginar como as personagens e a história poderiam ser ilustrados, por isso, alguns conceitos precisariam estar claros. Todavia, como a temática do Cerrado permeia o conteúdo escolar e o cotidiano dos alunos, algumas imagens já estavam previamente estabelecidas, como a vegetação em que vivemos no Centro-Oeste. Conforme Bakhtin (2016, p. 26), “[...] todo falante é por si mesmo responde em maior e menor grau: porque ele não é o primeiro falante, o primeiro a ter violado o eterno silêncio do universo [...] cada enunciado é um elo na corrente complexamente organizada de outros enunciados". Isso quer dizer que o acesso pré- 
vio aos conhecimentos do bioma Cerrado possibilitou criar as ilustrações, assim como o próprio entendimento do conto. Afinal, todo discurso é atravessado pelo de outrem, e nessa interação se formam as identidades. É nesta direção que conseguimos vislumbrar que o trabalho com as $\mathrm{HQ}$ em sala de aula pode ser proveitoso para os alunos, tendo em mente que diversos aspectos socioculturais são trabalhados, indo ao encontro do letramento literário. Entendido, por nós, neste trabalho, como capacidade de fazer uso social da literatura em sua vivência diária.

Dessa forma, quando o aluno para e pensa sobre a história, levando em conta os aspectos que são inatos a ela, ele necessita refletir sobre o que já está posto e sobre o que necessita ser acrescentado. Por esse fator, acaba ressignificando sua própria percepção artística-literária. Isso acaba fazendo com ele consiga desenvolver uma apreciação estética aflorada da obra, bem como o ajuda desenvolver capacidades de criação. Por conseguinte, acreditamos que a mudança do gênero conto para o gênero $H Q$ suscitou nos alunos grandes significados, uma vez que propôs um desafio, algo que, para Vigostky (2009), é fundamental para o processo de criação. Para este autor, se estamos em conformidade com a realidade posta, a atividade de criar não ocorrerá, pois ela necessita de um desejo que coloque em prática o exercício de imaginar. Posto isso, observamos que transformar o conto em $\mathrm{HQ}$ foi de grande valia à formação literária e artística de nossos alunos.

\section{CONCLUSÃO}

Em suma, o trabalho objetivou demonstrar como as $\mathrm{HQ}$ influenciam no desenvolvimento e na aquisição de um letramento literário, concomitante ao desenvolvimento do hábito leitor. Para tanto, utilizamos como instrumentos as $\mathrm{HQ}$ produzidas pelos alunos do projeto Ponto de Apoio do CEPAE/UFG. Além de ser um trabalho proveitoso para os estudantes, professores e familiares, vai ao encontro daquilo que os PCN expressam sobre dar direcionamentos e outros fins aos trabalhos que são desenvolvidos pelos alunos. Dessa forma, é plausível compartilhar essas experiências. 
Além disso, ressaltamos que quando os alunos são confrontados com atividades desse tipo (produção de $\mathrm{HQ}$ ), eles são instigados a imaginar, a criar, a colocar em prática o que entenderam - sua percepção de mundo, sua percepção de arte. Por isso, acreditamos que as histórias em quadrinhos têm importância acentuada para a aquisição do letramento literário, tendo em vista que instiga os alunos em suas múltiplas facetas e vozes a agir socialmente pela e na literatura. A partir do conto Ninho de periquitos, de Hugo de Carvalho Ramos, muitas obras terão significado diferentes para os alunos contemplados pelo projeto, e isso poderá ajudar na constituição identitária de leitores, escritores e literatos.

Para que a atividade proposta tenha um efeito significativo é necessário que o professor esteja atento ao seu papel, propiciando o contato do aluno com instrumentos mediadores que possibilitem o seu desenvolvimento (VIGOTSKY, 2001). Além disso, como vimos o trabalho com os gêneros discursivos possibilita a aquisição de muitas competências e habilidades que podem atuar diretamente na formação acadêmica e social do estudante, fazendo-o agir socialmente. Isso contribui inclusive para que ele exerça sua cidadania. Por isso, acreditamos que a sociedade necessita de 'mais literatura' e concordamos com Cândido (1995) de que ela deveria ser um direito humano, para que a sociedade não seja mutilada e consiga resistir em tempos sombrios.

Concluímos que o trabalho não está pronto e acabado, mas é necessário dar um efeito de acabamento a ele (BAKHTIN, 2016). Por isso, consideramos válidas todas as propostas que visem complementá-lo. Além disso, outras propostas podem ser desenvolvidas a partir do presente estudo; por exemplo: como as $\mathrm{HQ}$ atuam na formação identitária de leitores e escritores que já leem e escrevem há muito tempo? Como a autoria pode ser trabalhada nas histórias em quadrinhos? Entre outras problemáticas.

\section{REFERÊNCIAS}

ARAÚJO, Gustavo C.; COSTA, Mauricio A.; COSTA, Evâneio B. As histórias em quadrinhos na educação: possibilidades de um recurso didático-pedagógico/Stories In Comics In Education: Possibilities Of A Teaching-Educational Resource. A Margem, v. 1, n. 2, p. 26-36, 2008. 
BAKHTIN, Mikhail. O autor e a personagem na atividade estética. Estética da criação verbal. v. 5, p. 3-192, 2003

BAKHTIN, M. Questões de estilística no ensino da língua. Tradução, posfácio e notas de Sheila Grillo e Ekaterina Vólkova Américo; apresentação de Beth Brait; organização e notas da edição russa de Serguei Botcharov e Liudmila Gogotichvíli. São Paulo: Editora 34, 2013.

BAKHTIN, M. Os gêneros do discurso. Organização, tradução, posfácio e notas: Paulo Bezerra. São Paulo: Editora 34, 2016.

BARBOSA, A. Os quadrinhos no ensino de artes. In: RAMA, A; VERGUEIRO, W. Como usar as histórias em quadrinhos na sala de aula. 4. ed. São Paulo: Editora Contexto, 2010. p. 56-68

BOSI, A. História concisa da literatura brasileira. 43. ed. São Paulo. Cultrix: 2006.

BRASIL. Ministério da Educação. Guia Digital do Programa Nacional do Livro e do Material Didático (PNLD) 2018 - Literário. Brasília: Ministério da Educação, 2018. Disponível em: <http://pnld.nees.com.br/pnld_2018_literario/inicio>. Acesso em: 25 out. 2018.

BRASIL. Ministério da Educação Parâmetros Curriculares Nacionais. Linguagens, códigos e suas tecnologias. Brasília: Ministério da Educação/ Secretaria de Educação Média e Tecnológica, 1998.

BRASIL. Ministério da Educação. Base Nacional Comum Curricular. Brasília: Ministério da Educação, 2017.

CÂNDIDO, A. et al. O direito à literatura. Vários escritos, v. 3, p. 235-263, 1995.

COSSON, R. Letramento literário: teoria e prática. São Paulo: Contexto, 2009.

FARACO, C. A. Linguagem \& diálogo: as ideias linguísticas do círculo de Bakhtin. Curitiba: Criar, 2003.

RAMOS, Hugo de Carvalho. Tropas e boiadas. Goiânia: ICBC, 2006. 
ROCHA, Luciana Parente; MORAES, Moema Gomes; SILVA, Rusvênia Luiza. $O$ ponto de apoio de matemática: relato de experiências no Cepae da UFG. In: ENCONTRO NACIONAL DE DIDÁTICA E PRÁTICAS DE ENSINO, 16, Campinas. Anais... Campinas: UNICAMP, 2012.

SANTOS, W. A. dos. Literatura e história em quadrinhos (HQ) na educação básica. 2015. 92 f. Dissertação (Mestrado m Ensino na Educação Básica) - Centro de Ensino e Pesquisa Aplicada à Educação - CEPAE, Universidade Federal de Goiás, Goiânia, 2015. Disponível em: <https://repositorio.bc.ufg.br/tede/handle/tede/7515>. Acesso em: 20 set. 2018.

SANTOS, M. O. dos; GANZAROLLI, M. E. Histórias em quadrinhos: formando leitores. Transinformação [online]. 2011, vol.23, n.1, pp.63-75. Disponível em: http://dx.doi.org/10.1590/S0103-37862011000100006. Acesso em 19 de fevereiro de 2019.

VERGUEIRO, W. A linguagem dos quadrinhos: uma alfabetização necessária. In: RAMA, Angela; VERGUEIRO, Waldomiro. Como usar as histórias em quadrinhos na sala de aula. 4. ed. São Paulo: Editora Contexto, 2010.

VIGOTSKI, L. Imaginação e criação na infância. Tradução Zoia Prestes. São Paulo: Ática, 2009.

A construção do pensamento e da linguagem. Trad. Paulo Bezerra. São Paulo: Martins Fontes, 2001. (Psicologia e Pedagogia).

VILELA, T. Os quadrinhos no ensino de história. In: RAMA, Angela; VERGUEI$\mathrm{RO}$, Waldomiro. Como usar as histórias em quadrinhos na sala de aula. 4. ed. São Paulo: Editora Contexto, 2010.

VOLÓCHINOV, V. Marxismo e filosofia da linguagem: problemas fundamentais do método sociológico na ciência da linguagem Tradução, notas e glossário de Sheila Grillo e Ekaterina Vólkova Américo. Ensaio introdutório de Sheila Grillo. São Paulo: 34, 2017. 
dol $10.48209 / 978-65-89949-16-3$
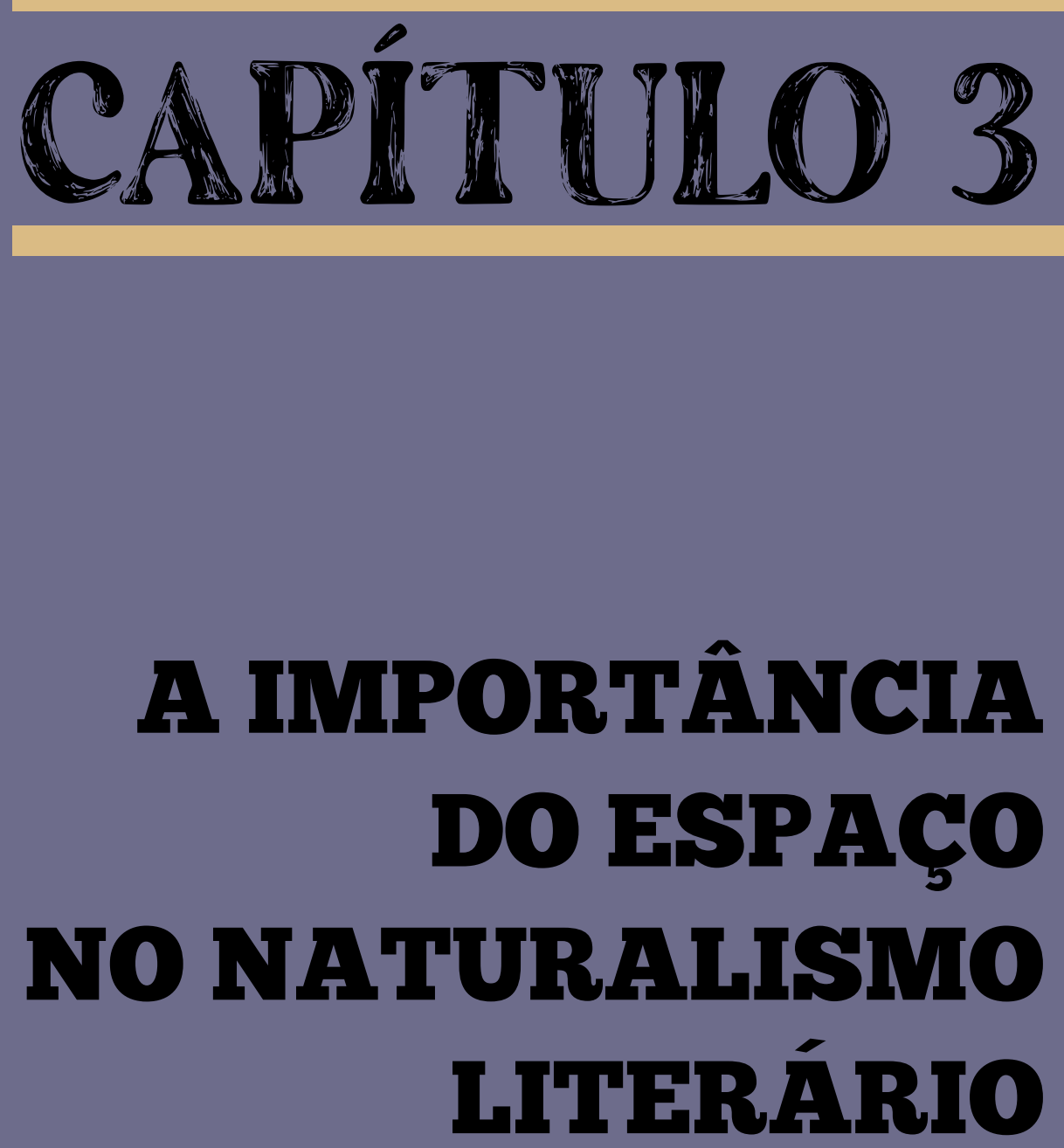

Márnei Consul 


\section{INTRODUÇÃO}

No interior do Realismo (movimento literário iniciado em 1881 no Brasil), identifica-se uma tendência chamada Naturalismo, que via o comportamento humano como uma reação condicionada pela influência do meio social e pelas características físicas e psicológicas hereditárias.

Para os naturalistas, o ser humano não passa de um produto biológico sujeito às leis naturais. Por isso, em dadas circunstâncias, seu comportamento pode ser facilmente previsto, eis que ele teria sempre as mesmas reações instintivas e incontroláveis.

Uma das características do período literário naturalista é que o espaço (às vezes, entendido como ambiente ou cenário) é muito levado em conta. É como se ele fosse um personagem da história, condicionando ações e atitudes.

Neste sentido, este artigo se propõe a demonstrar a importância do espaço no período do Naturalismo, a partir de pesquisa bibliográfica, baseando-se na leitura das obras literárias, bem como na consulta de estudiosos sobre o tema. Primeiramente, conceitua-se tal movimento literário. Em seguida, são feitas considerações sobre literatura, espaço e ambiente. Por fim, mostram-se exemplos retirados das obras O Ateneu, de Raul Pompéia, Bom-Crioulo, de Adolfo Caminha, e O cortiço, de Aluísio Azevedo, obras que são exponenciais no período referido.

\section{CONCEITUANDO NATURALISMO}

Integrando o Realismo - movimento da literatura com início em 1881 no Brasil - encontramos uma tendência denominada Naturalismo. Ela tinha o comportamento dos homens como uma reação condicionada pela influência do meio social e por características hereditárias (físicas e psicológicas).

Segundo Leila Lauar Sarmento e Douglas Tufano (2004), para os naturalistas, o ser humano não passa de um produto biológico sujeito às leis da natureza; 
por isso, em certas circunstâncias, seu comportamento pode ser facilmente previsto, pois ele teria sempre as mesmas reações instintivas e incontroláveis.

Conforme Sergius Gonzaga (1998), o Naturalismo é um prolongamento do Realismo. Ambos os movimentos são quase paralelos, e muitos críticos veem no primeiro uma manifestação do segundo. "Com efeito, o Naturalismo assume todos os princípios e características do Realismo, tais como o predomínio da objetividade, da observação, da verossimilhança, etc., acrescentando a isso uma visão cienticifista da existência" (GONZAGA, 1998, p. 90).

Ainda sobre o período, é importante dizer que "a narrativa naturalista é marcada pela vigorosa análise social a partir de grupos humanos marginalizados, em que se valoriza o coletivo" (NICOLA, 2007, p. 283).

Uma das características do Naturalismo é o determinismo do meio ambiente, a qual reza que "o homem é o produto do seu meio, esta é uma das teses centrais do movimento. Uma projeção do seu cenário, com o qual se confunde e do qual não consegue escapar" (GONZAGA, 1998, p. 91).

O determinismo sugere que o comportamento humano é determinado por forças biológicas (como instinto e herança genética), sociológicas e ambientais (ecologia e meio social) e históricas. Desta forma, tudo - inclusive a arte - é produto do meio, incluindo-se aí os fatos psicológicos e sociais.

As circunstâncias externas determinam rigidamente a natureza dos seres vivos, inclusive do homem; nem a razão nem a vontade escapam desse condicionamento. Toda a realidade passa por um processo evolutivo, dentro de um sistema de leis naturais absolutamente definidas. (...) o determinismo surge na perspectiva em que os narradores criam suas personagens. A neutralidade, suposta, não oculta o fato do autor sempre carregar com tons obscuros o destino de suas personagens. Seguindo a linha de raciocínio dessa teoria, se um indivíduo nasceu pobre, irá morrer pobre; sempre empregado, jamais patrão; filha de prostituta será sempre outra prostituta (SILVA, 2020, p. 13).

Ainda sobre o referido período, é possível dizer, nos passos de Luís Agostinho Cadore (1998), que 
o Naturalismo é o Realismo fortalecido por uma teoria peculiar de cunho científico, uma visão materialista do homem, da vida e da sociedade; é a teoria de que arte deve conformar-se com a natureza, utilizando-se dos métodos científicos de observação e experimentação no tratamento dos fatos e dos personagens (CADORE, 1998, p. 290).

\section{O autor continua:}

Há, contudo, semelhanças e diferenças entre Realismo e Naturalismo. Os realistas são grandes narradores que captam o drama dinâmico da vida, na sua realidade global; os realistas-naturalistas, negando, no fundo, a liberdade humana, submetem a vida a determinismos estáticos. Em suas obras, abordam quase sempre os mesmos temas: miséria, adultério, crime, desequilíbrio, aberração sexual, etc. E o ser humano, em face desses problemas, sucumbe fatalmente. Nos romances naturalistas, há protagonistas e vítimas; não existem heróis ou líderes (CADORE, 1998, p. 291).

Com relação aos temas das obras, José de Nicola (2007) nos diz que

a influência de Darwin se faz sentir na máxima naturalista que enfatiza a natureza animal do homem: antes de usar a razão, o homem se deixaria levar pelos instintos naturais, não podendo ser reprimido em suas manifestações instintivas - como o sexo - pela moral da classe dominante; a constante repressão levaria às taras patológicas, tão ao gosto naturalista. Em consequência, esses romances apresentam descrições minuciosas de atos sexuais e tratam de temas até então proibidos (NICOLA, 2007, p. 283).

Neste sentido, pode-se perceber que os personagens ficam mais sujeitos, de fato, ao ambiente que os cerca, aos determinismos mencionados acima. Eles são influenciados por isso. Cabe agora, então, analisar o que é "ambiente" em literatura.

\section{LITERATURA, ESPAÇO E AMBIENTE}

Ao falar-se de literatura, está-se falando de linguagem literária, a qual ocorre quando o texto é subjetivo e artístico. Tal linguagem é conotativa, preocupa-se mais com a forma e, muitas vezes, tem sentido múltiplo, polissêmico.

Neste ínterim, temos a literatura. Em sentido amplo, dá-se o nome de literatura ao conjunto da produção escrita. Já em sentido estrito, entretanto, literatura é a ficção, a criação de uma suprarrealidade, com os dados profundos, singula- 
res, da intuição do artista: "De modo geral, podemos dizer que literatura é a arte que se manifesta por meio da palavra escrita ou falada" (CADORE, 1998, p. 33).

Com base nisso, é certo dizer que literatura é a arte da palavra. A pintura é uma arte que se expressa por meio de cores e formas. A música também é uma arte e utiliza os sons para se manifestar. A dança, os movimentos; a arquitetura, as formas; o cinema, a imagem. Cada arte tem seu segredo. O segredo da literatura está na palavra artisticamente empregada.

Em literatura, temos os gêneros literários (lírico, dramático e narrativo). Tocante ao narrativo, há diferentes espécies narrativas. O conto e a crônica se caracterizam, em geral, pela narrativa curta; a novela, pela narrativa média; e o romance, pela longa.

Tocante a tais espécies, há os elementos da narrativa. Um deles é o ambiente, o qual

é o espaço - físico, social ou ambos - onde se desenvolve a ação dos personagens. Como exemplo de espaço físico, podemos citar uma cidade, um bairro, um vagão de trem, uma fazenda, etc. O espaço social equivale ao pano de fundo, que pode ser um cenário histórico também denominado paisagem (CADORE, 1998, p. 64).

Dentro do texto literário, a criação do espaço serve a diversos propósitos. Um deles é caracterizar os personagens, situando-as no contexto socioeconômico e psicológico em que vivem.

Muitas vezes, mesmo antes de qualquer ação, é possível prever quais serão as atitudes da personagem, pois essas ações já foram indiciadas no espaço que a mesma ocupa. Note que esses espaços são fixos da personagem, são espaços em que elas moram ou frequentam com grande assiduidade (BORGES FILHO, 2020, p. 1).

Outro propósito é influenciar as personagens e, também, sofrer suas ações.

Outras vezes, o espaço não somente explicita o que é ou será a personagem. Muitas vezes, o espaço influencia a personagem a agir de determinada maneira. Os exemplos mais claros dessa relação poderão ser encontrados, na literatura brasileira, nos romances naturalistas. Exemplo dessa função espacial pode ser encontrado no personagem Jerônimo, em O cortiço, de Aluízio Azevedo. Vindo de Portugal, Jerônimo, no início do enredo, é o mais trabalhador de todos os habitantes do cortiço. No entanto, com o tempo, vai sendo influenciado pelo espaço em que vive 
até se tornar um trabalhador relapso. O que era diferente vai-se homogeneizando através do espaço em que vive (BORGES FILHO, 2020, p. 2).

O autor sintetiza: "O ambiente se define como a soma de cenário ou natureza mais a impregnação de um clima psicológico. Esquematicamente, teríamos: $\left.1^{\circ}\right)$ Cenário + clima psicológico $=$ ambiente; e $2^{\circ}$ ) Natureza + clima psicológico $=$ ambiente" (BORGES FILHO, 2020, p. 5).

Desta forma, é preciso levar em conta os ambientes em que as histórias são construídas. Com certeza, eles nos dirão muito sobre as narrativas, o que ocorre muito bem no período naturalista, conforme veremos a seguir.

Entretanto, podemos entender espaço e ambiente como sendo sinônimos? Dimas (1994) e Lins (1976) abordam o tema.

\section{DISTINÇÃO ENTRE ESPAÇO E AMBIENTE}

Dimas (1994) conta-nos que existe uma relação tensa entre os elementos fundamentais da narrativa, ou seja, tempo, personagem e enredo. Geralmente, o espaço tem como função articular os demais elementos, assim como o tempo desempenha tal papel.

Com relação à distinção entre espaço e ambientação, o autor acima citado afirma que, para a aferição do primeiro, leva-se em conta a experiência de mundo; já para abordar a segunda, transparecem recursos expressivos do autor, o que pressupõe conhecimento da arte narrativa.

Para o crítico, a ambientação é diferente de espaço: a primeira define-se como um grupo de fatos, acontecimentos, sentimentos, etc. que compõem um ambiente, isto é, que estruturam os locais de acontecimento componentes da narrativa. Tocante ao espaço, trata-se da experiência ou da visão de mundo que o autor quer transmitir para a narrativa, objetivando fundamentar a ambientação.

Sabemos que ambos se relacionam intrinsicamente, o que dificulta estabelecer uma diferenciação. O leitor deve ser educado em suas leituras e familia- 
rizar-se com a literatura, a fim de que consiga distinguir espaço e ambientação, sendo capaz de perceber que esta é construída por meio da conotação (as palavras assumem diversos significados) e que aquele é construído pela denotação (as palavras têm sentidos concretos). Ambientação é implícita e subjetiva; espaço é explicito e objetivo, contendo elementos do mundo real.

Sobre a ambientação de forma específica, Lins (1976) classifica-a em três esferas: franca, reflexa e dissimulada. Na primeira, temos um narrador independente; na segunda, há o ponto de vista de cada personagem; na terceira, por fim, há menos descrições para que não haja vazios literários no texto e para que o ritmo narrativo não seja prejudicado. Ademais, a dissimulada exige a personagem viva, fazendo com que seja criada uma harmonização satisfatória entre espaço e ação.

Sobre o espaço, de maneira específica, o autor ora mencionado diz-nos que ele nos proporciona grandes possibilidades de estudo.

Observa-se que, em algumas narrativas, o espaço é rarefeito e impreciso. Mesmo então (...), há desígnios precisos ligados ao problema espacial: intenta-se, por um lado, concentrar o interesse nas personagens ou nas motivações psicológicas que as enredam; pode ser também que se procure insinuar - mediante a rarefação e a imprecisão do espaço que essas mesmas personagens e as relações entre elas são mais ou menos gerais, eternas por assim dizer, carentes, portanto, de significado histórico ou sociológico: de significado circunstancial. Entretanto, inclusive neste caso, alcançam, em geral, vibração mais intensa aquelas obras onde o espaço atua com o seu peso. A impossibilidade de ingresso num determinado espaço, espaço que ocupa o centro do romance exatamente por ser inacessível (LINS, 1976, p. 65).

A citação acima serve às obras naturalistas, onde o espaço está no centro das atenções. Não é inacessível, mas é fundamental para o desenrolar dos fatos, conforme veremos adiante.

Lins (1976) continua a explanação, afirmando que os espaços

(...) constituem uma ilustração das suas possibilidades; reforçam, simultaneamente, a importância que pode ter na ficção esse elemento estrutural e indicam as proporções que eventualmente alcança o fator espacial numa determinada narrativa, chegando a ser, em alguns casos, o móvel, o fulcro, a fonte da ação (LINS, 1976, p. 67). 
De fato, nas obras naturalistas, o espaço é essencial à narrativa e, em diversos casos, pode ser tido como motor da história, segundo veremos em $O$ cortiço, O Ateneu e Bom crioulo.

Lins (1976) fala, também, sobre espaço social e atmosfera. Ele diz que um não pode ser confundido com a outra.

Estando a noção de atmosfera associada ao espaço e denotando, inclusive, o ar que respiramos, tende-se a concebê-la, no estudo da ficção, como uma manifestação do espaço, ou, no mínimo, como sua decorrência (LINS, 1976, p. 75).

O autor vai adiante:

(...) a atmosfera, designação ligada à ideia de espaço, sendo invariavelmente de caráter abstrato - de angústia, de alegria, de exaltação, de violência, etc. - consiste em algo que envolve ou penetra, de maneira sutil, as personagens, mas não decorre necessariamente do espaço, embora surja com frequência como emanação deste elemento, havendo mesmo casos em que o espaço se justifica exatamente pela atmosfera que provoca (LINS, 1976, p. 76).

Não seria o caso das obras do Naturalismo? Passamos à análise delas.

\section{ANÁLISE DE ESPAÇOS EM OBRAS NATURALISTAS}

\section{O CORTIÇO}

No Brasil, o movimento literário naturalista estruturou-se com O mulato, de Aluísio Azevedo, em 1881. O mesmo autor também é responsável pela obra O cortiço (1890), que teve grande repercussão no país. Consoante Gonzaga (1998), o desenvolvimento urbano do Rio de Janeiro, ocasionado pela liberação do capital comercial envolvido na escravidão, gerara múltiplas atividades que implicariam o aumento geométrico da população e o aparecimento de núcleos habitacionais, denominados cortiços, onde se aglomeravam milhares de pessoas, trabalhadores e gente de atividade incerta. A evolução de Aluísio Azevedo ocorreu com $O$ cortiço, livro em que "as melhores ideias do Naturalismo se conjugaram com a revelação da miséria existente na capital do país" (GONZAGA, 1998, p. 94). 
Vejamos um trecho da obra, o qual comprova o dito acima:

Noventa e cinco casinhas comportou a imensa estalagem.

As casinhas eram alugadas por mês e as tinas por dia: tudo pago adiantado. (...)

Graças à abundância de água que lá havia, como eu nenhuma outra parte, e graças ao muito espaço de que se dispunha no cortiço para estender a roupa, a concorrência às tinas não se fez esperar; acudiram lavadeiras de todos os pontos da cidade, entre elas algumas vindas de bem longe. $\mathrm{E}$, mal vagava uma das casinhas, ou um quarto, um canto onde coubesse um colchão, surgia uma nuvem de pretendentes a disputá-los (AZEVEDO, 2020, p. 14).

Em outro trecho, percebemos que o espaço é descrito em toda a sua sujeira, podridão e promiscuidade. O autor não esconde a náusea diante daquilo que revela. A todo momento, ele compara os moradores do cortiço a animais:

E naquela terra encharcada e fumegante, naquela umidade quente e lodosa, começou a minhocar, a esfervilhar, a crescer, um mundo, uma coisa viva, uma geração que parecia brotar espontânea, ali mesmo, daquele lameiro, e multiplicar-se como larvas no esterco (AZEVEDO, 2020, p. 15).

Lins (1976, p. 69) afirma que há momentos em que o cenário serve de ambiente para a ação dos personagens e mais: que esse espaço serve para caracterizar socialmente os personagens. A caracterização do espaço no qual os personagens estão inseridos não serve somente para descrição física, mas também para mostrar a posição social dos envolvidos na história. O espaço social importa para a compreensão de ações feitas pelos personagens, seja no aspecto físico, seja nos conflitos psicológicos.

Miranda, vizinho desgostoso do cortiço, é personagem que descreve com constância o que ocorria nele, bem como quem o habitava:

À noite e aos domingos, ainda mais recrudescia o seu azedume, quando ele, recolhendo-se fatigado do serviço, deixava-se ficar estendido numa preguiçosa, junto à mesa da sala de jantar, e ouvia, a contragosto, o grosseiro rumor que vinha da estalagem numa exalação forte de animais cansados. Não podia chegar à janela sem receber no rosto aquele bafo, quente e sensual, que o embebedava com o seu fartum de bestas no coito (AZEVEDO, 2020, p. 16).

Acima, mais uma vez, temos a comparação das pessoas com animais, que é o que o espaço fazia com seus moradores: animalizá-los. No trecho abaixo, a 
mesma comparação, só que com destaque às crianças que, como animais jovens, defecam em qualquer lugar, sem necessidade de um espaço próprio para isso:

As portas das latrinas não descansavam, era um abrir e fechar de cada instante, um entrar e sair sem tréguas. Não se demoravam lá dentro e vinham ainda amarrando as calças ou as saias; as crianças não se davam ao trabalho de lá ir, despachavam-se ali mesmo, no capinzal dos fundos, por detrás da estalagem ou no recanto das hortas (AZEVEDO, 2020, p. 28).

O grande personagem do romance em tela é o próprio cortiço. "É ele quem determina o comportamento dos indivíduos que se moldam, agem e vivem de acordo com suas características Ora, se essa habitação coletiva é sórdida, os moradores também o serão" (GONZAGA, 1998, p. 95). Não há um protagonista humano principal, e sim uma série de figurantes, relacionados uns com os outros e, antes de tudo, com o cenário. Em síntese: "O romance é o nascimento, vida, paixão e morte de um cortiço" (NICOLA, 2007, p. 283).

\section{O ATENEU}

Outro autor tido como muito relevante no Naturalismo é Raul Pompéia. Em O Ateneu (1888), "a ação transcorre no ambiente fechado e corrupto de um internato, onde convivem crianças, adolescentes, professores e empregados. A narração dos fatos é feita por Sérgio, um ex-aluno da escola, que recorda os anos que passou no Ateneu" (SARMENTO; TUFANO, 2004, p. 103). Assim, o romance adquire caráter memorialista, o que é indicado pelo subtítulo "Crônica de saudades". Trata-se de um romance introspectivo: saindo do aconchego do lar, Sérgio "sente-se deslocado no ambiente agressivo e sensual do colégio, representação, em miniatura, da sociedade e do mundo" (SARMENTO; TUFANO, 2004, p. 103).

Eis um trecho que mostra o afirmado acima:

Não imagina, meu caro Sérgio. Conte como uma desgraça ter de viver com esta gente (...). Aí vão as carinhas sonsas, generosa mocidade... Uns perversos. Têm mais pecados na consciência que um confessor no ouvido; uma mentira em cada dente, um vício em cada polegada de pele.

(...) São servis, traidores, brutais, adulões. (...) Cheiram à corrupção, em- 
pestam de longe (POMPÉIA, 2020, p. 12).

Sérgio encontra o mundo no Ateneu, um mundo com regras próprias: normal, no local, é ser frustrado, complexado e homossexual. Nicola (2007) conta que, para os internos,

só há uma solução: a eternidade do Ateneu, nunca abandonar aquele mundo e sua "normalidade". No entanto, ao final do livro, Raul Pompéia Poméia destrói o Ateneu: um dos meninos, Américo, provoca um incêndio; é a vingança de Raul Pompéia, a destruição daquele mundo e de seu criador (NICOLA, 2007, p. 300).

O autor citado acima, sinteticamente, revela que O Ateneu "se trata

de um corte na decadente sociedade monárquica brasileira. Em várias passagens da narrativa, Raul Pompeia se refere ao internato como um microcosmo, ou seja, um pequeno espaço onde se reproduzem comportamentos, regras, atitudes que são características de uma sociedade mais ampla ou, como se dizia no Ateneu, "o grande mundo lá fora" (NICOLA, 2007, p. 299).

Em relação ao espaço, o colégio, o personagem principal demonstra desapreço por ele, como podemos notar no trecho abaixo, no qual ele descreve como ocorria a prática de natação:

Por ocasião dos intensos calores de fevereiro e março e do fim do ano, havia aí dois banhos por dia. E cada banho era uma festa, naquela água gorda, salobra da transpiração lavada das turmas precedentes, que as dimensões do tanque impediam a devida renovação; turbulento debate de corpos nus, estreitamente cingidos no calção de malha rajado a cores, enleando-se os rapazes como lampreias, uns imergindo, reaparecendo outros, olhos injetados, cabelos a escorrer pela cara, vergões na pele de involuntárias unhadas dos companheiros; entre gritos de alegria, gritos de susto, gritos de terror; os menores agrupados no raso, dando-se as mãos em cacho, espavoridos, se algum mais forte chegava (POMPÉIA, 2020, p. 15).

Ana Carolina Cruz (2010), referente ao espaço em O Ateneu, fala-nos de confinamento e limitação:

A estrutura do colégio é a de um edifício construído num quadrado murado, com um pátio central e diversos pavimentos, alguns inclusive independentes. $O$ fato relevante é que essa construção é descrita e caracterizada como uma "caixa desmedida de paredes", o que reitera a questão do confinamento, da limitação (CRUZ, 2010, p. 68). 
Com base na autora citada, percebe-se que, ao entrar para o restrito espaço do internato, este pode ser tido como um microcosmo de relações culturais e sociais desenhadas no espaço que o constitui. Cruz (2010) ainda fala sobre divisão de classes no interior do colégio:

Em contrapartida à parte superior, como não poderia deixar de ser, tudo o que remete à excreção, sujeira, classe baixa, necessidades fisiológicas, excreção localiza-se na parte inferior do internato, mais precisamente no subchão, palavra cujo prefixo "sub" inferioriza ainda mais, colocando o espaço da rouparia e da limpeza abaixo da linearidade do solo (CRUZ, 2010, p. 70).

O citado acima é evidenciado no trecho a seguir:

A rouparia ocupava grande parte do subchão do imenso edifício, entre o vigamento do soalho e a terra cimentada. Outra parte era destinada aos lavatórios, centenas de bacias, ao longo das paredes e pouco acima num friso de madeira os copos e as escovas de dentes. Terceiro compartimento, além destes, acomodava o arsenal dos aparelhos ginásticos e o dormitório da criadagem. Da rouparia para o recreio central atravessava-se obliquamente o saguão das bacias (POMÉIA, 2020, p. 11).

Conforme o personagem Sérgio, com sua crise do sentimento, "casava-se o receio que me infundia o microcosmo do Ateneu. Tudo ameaça os indefesos" (POMPÉIA, 2020, p. 17). O menino, ao mesmo tempo em que lamenta o incêndio que destruiu o internato, comemora isso:

O seu trabalho perdido, a conquista inapreciável dos seus esforços!... Em paz!... Não era um homem aquilo; era um de profundis. (...) Aqui suspendo a crônica das saudades. Saudades verdadeiramente? Puras recordações, saudades talvez, se ponderarmos que o tempo é a ocasião passageira dos fatos, mas sobretudo - o funeral para sempre das horas (POMPÉIA, 2020, p. 93).

Como se vê, o desprezo de Sérgio não é só pelo espaço, mas sim pelos fatos que lá ocorreram. Certamente, tudo de ruim que o menino lá enfrentou ficou personificado na figura do Ateneu. Com o fim do incêndio, findou, também, o sentimento de claustrofobia do personagem principal.

\section{BOM-CRIOULO}

Por fim, outra obra que merece destaque devido à importância do espaço nela é Bom-Crioulo (1895), de Adolfo Caminha. Escandaloso para a época, por 
abordar um romance homossexual, o romance se passa em dois espaços: no mar, a bordo de uma corveta, e na Rua da Misericórdia, localizada nos subúrbios do Rio de Janeiro. Os dois lugares são descritos em seus sentidos mais negativos e degradantes, destacando a miséria daqueles que lá vivem.

A obra, segundo Mendes e Lima (2020), permitiu que Adolfo Caminha firmasse sua reputação na história literária do Brasil. Publicada em 1895 (logo após a Proclamação da República e a difusão do Naturalismo na literatura brasileira), abordava temas ousados, diferentes daqueles em que o público da época era acostumado, como: homossexualidade, crime passional, erotismo, um triângulo amoroso no qual o protagonista é negro, sexo inter-racial etc.:

$\mathrm{Na}$ época, a obra não foi recebida com bons olhos, pois se opunha ao discurso moralista daquela sociedade, trazendo ainda o agravante de que seus personagens eram da Marinha Nacional, a qual recebeu com desagrado e rancor a ousadia do escritor, sobretudo por ele ter feito parte da marinha. Trata-se de uma obra cuja importância foi completamente ignorada na época de sua publicação e, somente nos últimos anos, vem ganhando espaço no meio literário, não apenas como uma obra-prima, mas também como uma forma de denúncia contra os maus-tratos aos marinheiros e às condições em que viviam (MENDES e LIMA, 2020, p. 143)

O ambiente de bordo é marcado pelo trabalho árduo e por uma vida sem privacidade, o que possibilita diversas perversões. $O$ ajuntamento de homens favorecia a promiscuidade, como se nota em:

Mas havia ordem para não desembarcar, e Bom-Crioulo, como toda a guarnição, passou a tarde numa sensaboria, cabeceando de fadiga e sono, ocupado em pequenos trabalhos de asseio e manobras rudimentares. - Diabo de vida sem descanso! O tempo era pouco para um desgraçado cumprir todas as ordens. E não as cumprisse! Golilha com ele, quando não era logo metido em ferros... Ah! Vida, vida!... Escravo na fazenda, escravo a bordo, escravo em toda parte... E chamava-se a isso servir à Pátria! (CAMINHA, 2020, p. 58).

Ao retratar o espaço urbano, Caminha fala a respeito de um tipo de moradia muito comum no Rio de Janeiro durante o final do século XIX: as habitações coletivas. Os habitantes delas eram brancos, mulatos e mestiços, sempre pessoas exploradas. Ao redor das habitações, há negociantes que se aproveitam, de algum modo, da miséria dessas pessoas. 
Analisando a obra, percebe-se que foi a transformação de Aleixo que o levou ao seu desfecho trágico, o qual que está ligado ao determinismo, talvez por seu impulso em tomar decisões perante Amaro, porém, perante a ideia de que o individuo é mandado pelo meio, oportunidade em que Aleixo se deixa envolver pela deslealdade de Dona Carolina, o que resultou em sua morte por fim.

No caso do personagem de Amaro, que se apaixona e definha por esse amor, ressalvo que, apesar de querer como posse o jovem grumete, as circunstâncias foram requisitos determinantes para que colocasse fim à vida de Aleixo, o que demonstra que voltou a ser o antigo negro rude do início do livro, disposto a todo tipo de violência quando provocado (MENDES; LIMA, 2020, p. 149).

Assim sendo, notamos que o comportamento dos personagens é determinado pela pobreza do ambiente que as circula e que, por sua vez, decorre do momento histórico do Brasil: o Segundo Reinado.

\section{SINTETIZANDO OS ESPAÇOS APRESENTADOS}

Com base nas obras apresentadas, vimos os seguintes espaços: um cortiço (habitação popular); um colégio interno; uma embarcação; e uma rua. Tais espaços contribuíram muito para o desenrolar das histórias, integrando-se aos ambientes e agindo sobre os personagens, de acordo com o que já expusemos.

Pode-se dizer que

(...) o espaço, no romance, tem sido - ou assim pode entender-se - tudo que, intencionalmente disposto, enquadra a personagem e que, inventariado, tanto pode ser absorvido como acrescentado pela personagem, sucedendo, inclusive, ser constituído por figuras humanas, então coisificadas ou com a sua individualidade tendendo para zero (LINS, 1976, p. 72).

A partir do escrito acima, pudemos perceber que, em $O$ cortiço, dois espaços são explorados. O cortiço é um amontoado de casebres, onde vivem os pobres. Tal espaço é a representação da mistura de raças com a promiscuidade das classes baixas. Ele funciona como um organismo vivo. Ao lado do cortiço, temos o segundo espaço: um sobrado aristocrático do comerciante Miranda e de sua família. Ele representa a burguesia crescente do século XIX. 
Em O Ateneu, o espaço é tido como um lugar de confinamento (até de clausura), seja no aspecto físico que o constitui, seja nos discursos veiculados nele. Pode-se dizer que se trata de um espaço claustrofóbico, representando o poder das relações sociais. Instaurado no último capítulo, o fogo parece ser o instrumento mais adequado para romper tal confinamento, encerrando o espaço sufocante do internato, bem como de seu simbólico universo. O espaço educacional apresentado no livro é a visão de um mundo. É mostrado, no internato, um conjunto de situações e de organização espacial que denotam similaridade com a questão de poder, de imposição disciplinar, algo quase militarista.

Por fim, em Bom-Crioulo, as ações de Amaro (personagem principal) condizem com os dois espaços principais da obra. Na embarcação, o bom crioulo tem momentos de plenitude e pujança, onde nem os castigos o abalam, já que ele é forte assim como a corveta em que está. Entretanto, quando sai dela, tem início sua decadência física e moral, do mesmo modo que o sobradinho da Rua da Misericórdia, local de uma prostituta que alugava quartos a pessoas sem qualificação. Amaro e Aleixo instalam-se em um quarto de sótão na trapeira, local de bugigangas, mau cheiro e de realização sexual.

Desta forma, o cenário não tende a funcionar apenas como um pano de fundo, isto é, estático, fora dos personagens. O oposto ocorre nas três obras estudadas neste artigo: os espaços, talvez, sejam a causa das ações dos personagens, ou, pelo menos, de boa parte delas. Os espaços espelham os personagens.

\section{CONCLUSÃO}

Percebe-se, ao longo das páginas anteriores, que o espaço tem muita relevância nas obras citadas, sendo isso uma característica muito forte no Naturalismo. O espaço ajuda o leitor a compreender a obra, é parte integrante do personagem, e não apenas pano de fundo ou palco onde acontecem as ações.

Os espaços naturais e os modificados pelo ser humano fazem parte do espaço da obra literária. Todos os elementos de distribuição do cenário e dos personagens, até mesmo os próprios personagens, integram o espaço. Ele pode 
justificar ou desencadear ações nas obras, conforme vimos nas análises de $O$ cortiço, O Ateneu e Bom-Crioulo.

Voltando-me para a educação, não posso deixar de mencionar que, com certeza, isso pode ser explorado com alunos do Ensino Médio, no sentido de trazer um questionamento a eles: o espaço em que vivemos nos determina como seres humanos? Será que somos o que somos devido ao lugar em que moramos? É possível mudar?

Desta maneira, penso que tais discentes devem ser motivados à leitura. Vale a pena investir na formação do leitor, o que significa incentivá-lo ao hábito, de modo a multiplicar a experiência literária. O primeiro passo para tal formação é a oferta de livros próximos à realidade do leitor, que levantem questões significativas para ele. Para nisso, a literatura brasileira e a literatura infanto-juvenil vêm preencher esses quesitos ao fornecerem textos diante dos quais o discente se situa pela linguagem, pelo ambiente, pelos caracteres dos personagens, pelos problemas. A familiaridade do leitor com o livro gera desencadeamento do ato de ler.

Fica aqui a dica a educadores e alunos: percebam o quanto o espaço importa nas obras naturalistas e, a partir disso, construam suas trajetórias de leitura, fortalecendo suas análises e apurando seus sensos críticos. O espaço influencia, contextualiza, forma e entretém.

\section{REFERÊNCIAS}

AZEVEDO, Aluísio. O cortiço. Disponível em: <https://www.livros-digitais.com/ aluisio-azevedo/o-cortico/sinopse>. Acesso em: 23 jul. 2020.

BORGES FILHO, Ozíris. Espaço e literatura: introdução à topoanálise. XI Congresso Internacional da ABRALIC Tessituras, Interações, Convergências, São Paulo, 13 a 17 jul. 2008.

CAMINHA, Adolfo. Bom crioulo. Disponível em: <http://www.ebooksbrasil.org/ adobeebook/bomcrioulo.pdf>. Acesso em: 30 jul. 2020. 
CADORE, Luís Agostinho. Curso Prático de Português: literatura, gramática, redação. 11. ed. São Paulo: Ática, 1998.

CRUZ, Ana Carolina de Picoli de Souza. O Ateneu de Raul Pompéia: uma claustrotopia - espaço de discursos modeladores. 2010. 143 f. Dissertação (mestrado) - Universidade Estadual Paulista, Faculdade de Ciências e Letras de Araraquara, 2010. Disponível em: <http://hdl.handle.net/11449/94000>.

DIMAS, Antonio. Espaço e romance. São Paulo: Ática, 1994.

GONZAGA, Sergius. Manual de literatura brasileira. 15. ed. Porto Alegre: Mercado Aberto, 1998.

LINS, Osman. Lima Barreto e o espaço romanesco. São Paulo: Ática, 1976.

MENDES, Rafaella de Queiroz; LIMA, Sheila Oliveira. A presença do determinismo em Bom-Crioulo, de Adolfo Caminha. Diálogos e Perspectivas, Londrina, 06 a 28 nov. 2012.

NICOLA, José de. Literatura brasileira: das origens aos nossos dias. 17. ed. São Paulo: Scipione, 2007.

POMPÉIA, Raul. O Ateneu. Disponível em: <http://www.dominiopublico.gov.br/ download/texto/bn000005.pdf>. Acesso em: 26 jul. 2020.

SARMENTO, Leila Lauar; TUFANO, Douglas. Português: literatura, gramática, produção de texto. 1. ed. São Paulo: Moderna, 2004.

SILVA, Felipe Antônio Ferreira da. Uma análise sobre a relevância do espaço como personagem na obra O cortiço, de Aluísio de Azevedo. Revela. Praia Grande, v. IV, n. VIII, jun. 2010. 
doi $10.48209 / 978-65-89949-16-4$

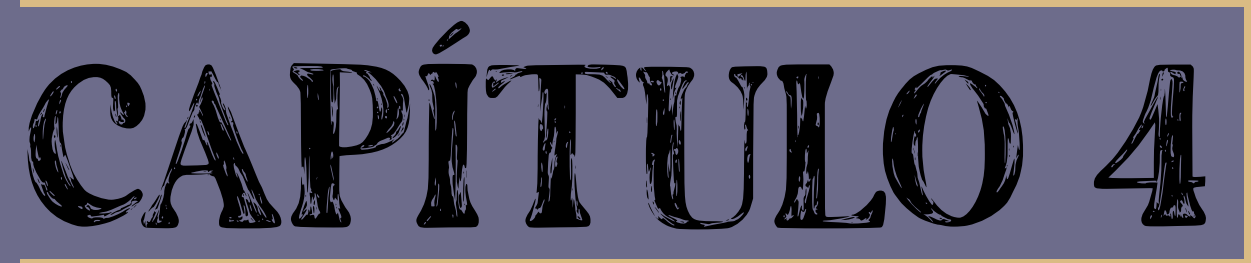

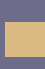

\section{UM OLHAR SOBRE ALGUNS} ASPECTOS TEMÁTICOS E

\section{ESTRUTURAIS EM O BERÇO DO HERÓI, DE DIASS GOMES}

Rondinele Aparecido Ribeiro

1 O presente trabalho foi realizado com apoio da Coordenação de Aperfeiçoamento de Pessoal de Nível Superior - Brasil (CAPES) - Código de Financiamento 001. 


\section{INTRODUÇÃO}

O presente artigo, parte dos resultados de uma pesquisa desenvolvida no Programa de Pós-Graduação em Letras da Universidade Estadual Paulista (UNESPIASSIS), analisa a peça O Berço do Herói, escrita por Dias Gomes. O estudo empreende uma análise estrutural da polêmica peça. Escrita em 1963, esse exemplar da dramaturgia nacional revela a postura de um intelectual inquieto e engajado. Dessa forma, a peça traduz-se como uma legítima representante do contexto problemático e ambivalente pelo qual o país passava no contexto em que foi escrita.

Com efeito, Dias Gomes é um dos escritores mais célebres da dramaturgia brasileira. Nasceu em Salvador no dia 19 de outubro de 1922. Filho de Plínio Alves Dias Gomes e Alice Ribeiro de Freitas Gomes, ficou órfão muito cedo (o pai morreu quando Dias Gomes contava com 03 anos de idade). Sua mãe assumiu sozinha a responsabilidade pela criação dos dois filhos: Alfredo e Guilherme. No ano de 1935, a família se mudou para o Rio de Janeiro pelo fato do irmão, já formado em medicina, manifestar o desejo de ingressar no exército.

A estreia do autor na cena literária ocorreu em 1937, ano em que foi escrita a peça teatral $A$ Comédia dos Moralistas. Peça premiada pelo Serviço Nacional do Teatro e pela União Nacional dos Estudantes, foi publicada dois anos mais tarde por intermédio de seu tio, na Fênix Gráfica da Bahia. Já no ano de 1941, durante a Segunda Guerra Mundial, o dramaturgo escreveu a peça Amanhã Será Outro Dia, que tematizava o nazismo, a invasão da França pela Alemanha e o exílio dos perseguidos políticos da América. A estreia profissional, contudo, ocorreu em 1942, com a comédia Pé de Cabra, peça primeiramente encenada no Rio de Janeiro e, depois, em São Paulo por Procópio Ferreira.

É possível afirmar que a trajetória traçada pelo intelectual se confunde com os contornos do teatro, do rádio e da televisão no país. "Consagrado como dramaturgo, roteirista de telenovelas, intelectual influente, eleito membro da Academia Brasileira de Letras, Dias Gomes foi figura decisiva no debate obscuro 
que, muitas vezes, opunha literatura e narrativa televisiva" (RESENDE, 2013, p. 11). Dono de uma produção multiforme e bastante inventiva, o conjunto de sua obra pode ser dividido em duas fases: a primeira, sem um grande reconhecimento de crítica, e a segunda, que engloba suas peças mais representativas e polêmicas, tais como O Pagador de Promessas, O Berço do Herói, O Bem Amado, A Invasão e O Santo Inquérito, peças escritas entre 1944 a 1969, período em que Dias Gomes exerceu paralelamente o ofício de dramaturgo e roteirista de rádio.

Com efeito, a estudiosa Iná Camargo Costa (2017) destaca que essa parceria foi bastante fértil por ter rendido a Dias Gomes um contrato de exclusividade para que o dramaturgo escrevesse quatro peças por ano. Nessa fase, foram escritas no ano de 1943 as peças Zeca Diabo, Doutor Ninguém, Um Pobre Gênio, Sinhazinha, Eu Acuso o Céu e João Cambão. Ainda em 1943, Dias Gomes ingressou no curso de Direito da Faculdade do Rio de Janeiro, curso que abandonaria dois anos depois. No ano de 1944, o dramaturgo ingressou no rádio. Por meio de um convite feito por Oduvaldo Vianna, Dias Gomes passou a trabalhar na recém-inaugurada Rádio Panamericana. Exercendo o ofício de escritor e roteirista, adaptou várias peças, romances e contos para o programa Grande Teatro Panamericano. No ano seguinte, transferiu-se para a Rádio Tupi-Difusora, em São Paulo. Nessa mesma época, ingressou no Partido Comunista, permanecendo até 1971.

\section{O BERÇO DO HERÓI: UMA PEÇA SUBVERSIVA}

Escrita em 1963 e publicada em 1965, a peça O Berço do Herói causou grande polêmica pelo fato de o Conselho de Segurança Nacional requisitar a prisão de Dias Gomes, de Paulo Francis - que redigiu o prefácio da obra - e de Ênio Silveira, autor da orelha do livro. No mesmo ano de publicação do livro, estava prevista a encenação da peça. O texto havia sido submetido à censura e autorizado para ser encenada sob a direção de Antônio Abujamra. "A peça abordava o mito do herói (e herói militar), tema delicado para o momento que atravessava o país. Tão delicado que acabou sendo proibida na noite que deveria ser encenada 
pela primeira vez" (GOMES, 2015, p. 07).

Nesse sentido, o ponto de vista de Beatriz Resende (2013) é bastante relevante. Ao tecer considerações acerca do plano composicional da peça, a crítica ressalta:

No meu entendimento, é a mais bem construída peça de Dias Gomes do ponto de vista dramático, e também a mais severa com as Forças Armadas. Trata-se da história da construção do mito de um herói, Jorge Roque, soldado fugido da guerra, que reaparece para atrapalhar os planos do poderoso Sinhozinho Malta, de sua amante Porcina ${ }^{4}$, a falsa viúva do falso herói, e de toda Asa Branca, uma pequena cidade-Estado. Impedida pela censura, em 1965, não chegou a ser encenada (RESENDE, 2013, p. 12).

Estruturada em 02 atos e 13 quadros, a peça tece uma sátira à construção de um herói alçado a contornos míticos em uma cidade que vive da exploração das vantagens constituídas a partir da alimentação de uma farsa no ideário popular. O jornalista Paulo Francis (2015) destaca, no prefácio da obra, o forte viés político do texto de Dias Gomes: "O Berço do Herói, de Dias Gomes, é uma comédia política, onde o mito do heroísmo vai pelos ares depois de examinado pelo autor à luz dos interesses da classe dominante de nosso país" (FRANCIS, 2015, p. 07).

Na peça, a personagem militar é elevada ao posto de herói. Todos acreditam que ele morreu em combate durante a Segunda Guerra Mundial. Por essa razão, é elevado ao posto de herói por, supostamente, ter morrido em defesa da honra da pátria. A cidade onde o militar morava na Bahia é rebatizada com o nome do herói. O local passou a ser palco da atração de romeiros, que peregrinam ao local devido ao aspecto sagrado atribuído à localidade. A economia do local se desenvolve em virtude da exploração do monopólio da fé. A localidade recebe, também, uma boate, fato que propicia um grande embate entre o grupo das beatas e das prostitutas.

4 A autora analisou a segunda versão da peça O Berço do Herói, revista pelo dramaturgo logo após o término da exibição da telenovela Roque Santeiro. Nessa nova versão, o autor incluiu falas que estiveram presentes na telenovela e renomeou as personagens. 
No decorrer das ações, a personagem retorna e sua presença na localidade pode levar a várias consequências, dentre elas, a decadência da cidade, que foi rebatizada com o nome do herói. Dessa forma, a peça mostra-se alinhada ao tom farsesco, que cede espaço para os contornos trágicos a partir da chegada do general, o qual é incumbido de resolver o impasse criado com o retorno desse herói, que, além de levar o espaço a uma derrocada, coloca o exército em uma posição de rebaixamento. Assim, essa postura questionadora sobre os falsos mitos revela aspectos subversivos da peça.

No artigo intitulado O Berço do Herói e As armas do Carlos, o dramaturgo explica o contexto da proibição da peça ocorrida no dia 22 de julho de 1963. Como salienta o escritor, a proibição do espetáculo deixou perplexo todos os envolvidos no projeto pelo fato de os originais terem sido enviados com 45 dias de antecedência aos censores e terem sido aprovados. Como era comum no contexto de cerceamento de liberdade de expressão, em se tratando de um espetáculo teatral, os censores solicitaram um ensaio geral para autorizarem definitivamente a encenação da peça. "Esse ensaio realizou-se um dia antes da estreia (que não houve), com a presença de dois censores e mais quatro cavalheiros de pedra (não falavam, não sorriam, acho que nem sequer pensavam" (GOMES, 2015, p. 126).

Seguindo nas trilhas responsáveis por desnudar o contexto de proibição de O Berço do Herói, Dias Gomes enfatiza uma situação fortemente acentuada pela arbitrariedade, haja vista que a proibição não foi determinada pelos censores, que haviam autorizado a montagem do espetáculo, sublinhando apenas algumas alterações inseridas no texto submetido. Diante dessa pequena alteração, sugeriram a supressão de tais acréscimos.

Diante dessa situação opressora, o elenco da peça decidiu conversar com o governador do Estado. Nesse momento, a equipe de artistas ficou sabendo que a ordem para a proibição da encenação do espetáculo havia partido dele. O fato é narrado por Dias Gomes: 
- Já sei, vocês vêm falar d' O Berço do Herói. Não adianta. Li a peça. É pornográfica e subversiva. Fui em que mandei proibi-la.

- Mas governador, a peça havia sido aprovada pela censura.

- Eu sei. Mas enquanto houver Constituição (!!!) neste País, peças desse tipo não serão permitidas. De agora em diante, vou ler todas e proibir uma por uma. Há algumas em cartaz que já deveriam ter sido proibidas. A do Nelson Rodrigues, por exemplo. Mas essa é só pornográfica. Dias Gomes é pior, é também subversivo. E vão embora daqui. Vão embora (GOMES, 2015, p. 132).

No prefácio da obra publicada pela Editora Bertrand Brasil, o polêmico jornalista Paulo Francis (2015) assinala o tema político da peça, que tem como mote a contradição entre a liberdade formal e a exploração do homem, temática que já havia sido abordada na peça O Pagador de Promessas. "Aqui repete-a comicamente, mas o resultado, para bom entendedor, não se altera. A liberdade formal, até esta, cessa de existir em nossa sociedade no momento em que contraria os donos do mercado" (FRANCIS, 2015, p. 07).

Paulo Francis (2015) resume a trama da peça da seguinte forma:

O Berço do Herói, de Dias Gomes, é uma comédia política, onde o mito do heroísmo vai pelos ares depois de examinado pelo autor à luz dos interesses da classe dominante em nosso País. O Cabo Jorge morreu como herói na FEB (Força Expedicionária Brasileira). Sua cidadezinha do interior apropria-se do seu nome. O chefe do local usa-o para obter verbas federais; o prefeito, para aumentar as rendas do município; o padre, para suas quermesses e atividades congêneres - o povo diz, à boca pequena, que o Senhor do Bonfim inspirou Jorge em sua arrancada contra os alemães; a prostituição está em plena expansão capitalista como fluxo de turistas; o Exército deu a um de seus batalhões o nome do herói (FRANCIS, 2015, p. 07).

Para a estudiosa Iná Camargo Costa (2017, p. 93), "a peça pode ser considerada subversiva até mesmo por detalhes como a inclusão de um soldado covarde bem como de um general mentiroso entre os elementos de sua trama". A autora, ao analisar a obra, comenta que ela apresenta vários méritos: o desenvolvimento de modo consequente de motivos, que já havia aparecido em peças anteriores, a maneira como são forjados heróis numa sociedade capitalista e o modo como essa sociedade parece valorizar mais a morte do que a vida. Assim, destacamos que o tema principal de O Berço do Herói centra-se em torno da morte e da mitificação. 
Do ponto de vista estrutural, Costa (2017) destaca na peça dirigida por Abujmra um forte sistema de gêneros pelo fato do início ser marcado pelo tom épico, mas evolui para a comédia de costumes. Para a estudiosa, o segundo e o último ato são notoriamente acentuados pela predominância do épico alternado com a comédia de costumes. "O autor não impõe ao conjunto a peça a forma épica, mesmo recorrendo a muitos de seus procedimentos e apesar de problematizar um dos pilares da forma dramática (o indivíduo livre)" (COSTA, 2017, p. 99).

Bastante relevante para a compreensão da obra é a contextualização apresentada pelo dramaturgo:

Que é isto? Uma comédia? Um drama? Uma tragédia? Talvez seja uma comédia com um background trágico. Background que cresce, à proporção que a peça se desenvolve e chega mesmo a ditar o clima de algumas cenas. Mas nem por isso deve constituir uma tônica na linha geral do espetáculo. Essa hibridez é proposital e jamais deverá ser eliminada, pois, através dela, muita coisa há a dizer. Ainda no que que diz respeito à forma, o épico é, frequentemente, quebrado por um tom de comédia doméstica. É um contraste que serve à ideia central da peça e à visão que ela pretende apresentar do mundo (GOMES, 2015, p. 11).

Cabo Jorge, protagonista da peça, tipifica o herói farsesco elevado a essa condição sem reunir elementos responsáveis para adquirir tal glória. O protagonista, um estudante de direito, foi convocado para a luta na Força Expedicionária Brasileira. No campo de batalha, assim como outros, acaba desertando por temer a morte. O general de seu batalhão escreve um relatório exaltando as qualidades do militar. Esse fato é responsável por transformar a cidade em que a personagem morava na Bahia em um local que experimenta um grande surto desenvolvimentista. Dessa forma, a figura do herói mitificado passa a alimentar o turismo e o comércio de relíquias, além de propiciar o surgimento da prostituição no local, marcando o desenvolvimento da cidade, que experimenta uma situação bastante ambígua, mas perfeitamente aplicável ao cenário do país: ao mesmo tempo em que se desenvolve urbanisticamente, continua mantendo laços de dependência da elite agrária, tipificada na peça pela personagem Major Chico Manga. 
No texto, há a presença do típico político:

O "Major" Chico Manga é o chefe político local. Negocista, demagogo, elegendo-se à custa a ignorância de uns e da venalidade de outros, convicto, entretanto, de ser credor da gratidão de todos pelas benfeitorias que têm conseguido para a cidade. E talvez, seja, até certo ponto. É dessa classe de políticos - bem numerosa, aliás, entre nós - que acha que o relativo bem que fazem os absolve de todo o mal que espalham. $E$ que se Deus fez o bem e o mal, foi para que coexistissem (GOMES, 2015, p. 20).

Paralelo a esse fato, ganha destaque outro aspecto também ligado ao farsesco: a presença da viúva Antonieta. Amante de Chico Manga, a personagem recebe legalmente as honras como viúva de cabo Jorge. Com o decreto da Anistia concedido aos desertores, o herói mitificado retorna para a cidade colocando em xeque todos os interesses dos envolvidos nas benesses propiciadas pela exploração do mito.

Ao analisar O Berço do Herói, o crítico Anatol Rosenfeld (1996) ressalta o caráter tragicômico da peça, uma vez que a temática central valoriza a morte tal qual em O Bem-Amado. Com efeito, é preciso ressaltar ainda o caráter extremamente provocativo das ações iniciais no momento em que um ator, ao se dirigir ao público, anuncia em um microfone que todos os heróis morreram:

ATOR (Pelo microfone): Notícia de falecimento. Morreram todos os heróis. (Outra vez o gongo)

ATOR: Transmitimos a notícia de falecimento de todos os heróis (GOMES, 2015, p. 17).

A partir do trecho transcrito, evidencia-se o conteúdo político da peça. A indagação do ator soa de maneira provocativa e questiona a ausência de heróis no país, o que revela o dimensionamento crítico do dramaturgo em problematizar temáticas polêmicas relacionadas ao seu projeto estético de criação de um teatro calcado na visão crítica da realidade. Na sequência, as ações focalizam a projeção de um filme sobre cabo Roque e sua atuação na Segunda Guerra Mundial. A tela e as luzes se apagam e o público é levado à praça onde as ações da peça transcorrem. Nesse espaço, estão reunidos os personagens da peça, que discutem a inauguração do monumento em homenagem ao herói dado como morto: 


\begin{abstract}
MAJOR CHICO MANGA (Discursando): Foi um herói, minha gente. Um herói de verdade. Graças a ele, as tropas brasileiras na Itália conquistaram seu primeiro triunfo. Graças a seu gesto magnífico, lançando-se de peito aberto contra a metralha, aquele batalhão, encorajado pelo seu exemplo, levou de roldão as terríveis hordas nazistas. Esta glória, que há de ficar para sempre gravada nas páginas da História, é também nossa, porque foi este o solo que lhe serviu de berço.
\end{abstract}

PREFEITO: Isso mesmo.

MAJOR: Mas foi preciso que se derramasse o sangue de um herói - e esse sangue era quase meu, como todos sabem, casado que sou com a tia dele - para que as autoridades federais tomassem conhecimento deste lugar, até então esquecido de Deus e dos homens. O feito heroico de Cabo Jorge atraiu para esta cidade jornalistas, cinegrafistas e turistas de toda a parte. No entanto, é preciso que se saiba também, meus patrícios, meu povo, que nada disso teria acontecido se este amigo de vocês não tivesse, na Câmara Federal, lutado como lutou para trazer até aqui o progresso, as conquistas da civilização cristã [...] (GOMES, 2015, p. 21).

O trecho transcrito é fortemente perpassado pela presença de um tom grandiloquente responsável por situar o feito do herói cultuado pela cidade, mas também revela a inclinação política calcada em relações de subserviência, fato que pode ser atestado pelo discurso do chefe político do local - descrito na apresentação da peça como "negocista" e "demagogo". O prólogo é finalizado com a presença de um coro, que serve para tencionar as ações e questionar a existência de heróis no país. Com regularidade na peça, sua presença evidencia a possibilidade anunciada de uma tragédia. Como destaca Costa (2017), a obra é marcada por um forte hibridismo devido sua apresentação com características épicas mescladas ao contorno trágico no decorrer das ações:

CORO (Sai do meio do povo, avança até o proscênio e canta):

Não são os heróis que fazem a História,

É a História

Quem faz heróis,

Porém no caso do nosso

Cabo Jorge,

Foi a História

Ou fomos nós? 


\section{Este ponto ficará esclarecido}

No decorrer

De nossa estória;

O que importa no momento esclarecer

É que sem ele,

Sem sua glória,

Este lugar não teria conhecido

As maravilhas

E as conquistas (GOMES, 2015, p. 23-24).

Na peça, sem a presença do herói, símbolo do consumo e do progresso da cidade, tudo se desmoronaria. Ambientada em 03 unidades espaciais: a praça (com o monumento do herói), a casa de Antonieta, o bordel (também chamado de "Castelo de Matilde", onde ocorre o desfecho marcado pela tragédia), a base cenográfica da peça é a praça, onde foi erigido um monumento em homenagem ao herói dado como morto por ter sido supostamente fuzilado durante a Segunda Guerra Mundial. Como destaca o dramaturgo, os demais ambientes serão apenas sugeridos com dois ou três objetos facilmente transportáveis.

Importante ressaltar que o espaço da praça na obra em análise de Dias Gomes mantém vínculos com elementos da carnavalização e do grotesco abordados por Bakhtin (2013). Na teoria proposta por Bakhtin (2013), a carnavalização pode ser vista como uma forma de deslocamento do espírito carnavalesco para a arte. Vista de modo ambivalente, sua essência centra-se no riso responsável por dessacralizar e relativizar os aspectos sérios e as verdades determinadas pelo fato de não empregar a denúncia negativa de caráter moral ou sociopolítico. $\mathrm{Na}$ literatura dita carnavalizada, emerge a zombaria, o aspecto jocoso, a gozação, a alegria e o destronamento das autoridades. Pode-se dizer, então, que essa literatura é marcada pela construção de um mundo em que a liberdade, a igualdade, a abundância e excentricidade são representadas num espaço onde tudo está às avessas. 
A partir do exposto, podemos afirmar que, em O Berço do Herói, o espaço é perpassado por situações em que o coletivo ganha destaque. Enquadra-se nessa categorização a praça, cenário onde ocorrem as quermesses, os comícios, as provocações e, consequentemente, onde se desnuda a exploração econômica do mito. Ademais, tendo se originado a partir dos diversos elos mediadores advindos de diferentes modalidades do folclore carnavalesco, a carnavalização, tratada por Bakhtin (2013) e assimilada pelas manifestações culturais, está calcada na concepção de festa popular, de folclore, dos costumes, da cultura e da história de uma sociedade. Pode-se constatar a assimilação dessa categoria estética na dramaturgia de Dias Gomes por meio das marcas típicas do exagero, do excesso e da transformação, o que acaba nos remetendo ao inacabado e ao ideal de um mundo às avessas.

Como marca estilística, Dias Gomes recorre ao emprego de uma linguagem reveladora de traços exagerados, mas bastante comuns, manifestada, sobretudo, nos discursos políticos acentuados por uma tonalidade altamente demagógica. Dessa forma, na praça, no momento em que vai ser inaugurado o monumento em homenagem a cabo Jorge, tem-se uma situação comum ao ideário popular relacionada ao riso:

POPULAR: Viva o Major Chico Manga!

TODOS: Viva!

MAJOR: Sei que não fiz mais do que o meu dever. Não fiz mais do que me mostrar digno de Cabo Jorge - símbolo da coragem, da virilidade e do espírito de sacrifício dos homens desta terra, do mesmo modo que aquela a quem deixou viúva é o símbolo da pureza e da honestidade de nossas mulheres. E ninguém melhor do que ela, a viúva do herói, ninguém mais merecedora da honra de inaugurar este monumento, erigido pelo povo desta cidade ao maior dos seus filhos, Cabo Jorge. (Aplausos. ANTONIETA levanta o rosto e o véu. Sorri para o povo, um sorriso de declamadora escolar em festa de fim de ano.)

ANTONIETA (Disfarçadamente, ao MAJOR): E agora, o que é que eu faço?

MAJOR (Discretamente, um pouco irritado): Não lhe disse, puxe a bandeira.

ANTONIETA: (Tenta retirar a bandeira que cobre o monumento, não conse- 
gue) - Algum engraçadinho prendeu a bandeira lá atrás. (MAJOR consegue desprender a bandeira. ANTONIETA descobre o monumento. Aplausos. ANTONIETA sorri, agradecendo, como se a homenagem fosse para ela.)

ANTONIETA (Após ligeira hesitação, sem saber se deve ou não agradecer): Eu acho que devo agradecer, não é? Já que ele, coitadinho, não pode. Se pudesse, vocês iam gostar, porque falava tão bem, dizia coisas tão bonitas... Não sei aonde ia buscar tanta coisa, palavra. (Major lança-lhe um olhar de desaprovação. Ela percebe) (GOMES, 2015, p. 22-23).

O Segundo Quadro do Primeiro Ato é perpassado por um grande tom festivo representado pela quermesse organizada pelo padre a fim de angariar fundos para a construção de uma nova igreja. Acentua-se, a partir desse ato, a exploração do mito da fé na cidade, pois, como forma de arrecadar mais dinheiro, o padre organiza a festividade para comemorar também o aniversário da primeira comunhão de Cabo Jorge. Dessa forma, evidencia-se a aproximação da obra de Dias Gomes às características tratadas por Bakhtin (2013) sobre a cosmovisão carnavalesca: imagens que retratam o corpo e suas necessidades bem como o excesso de comida, bebida, rebaixamento corporal e destronamento de autoridades constituem o sistema de imagens dessa cultura cômico - popular muito bem recriada por Dias Gomes.

Com efeito, é preciso destacar que Cabo Roque é um herói cultuado e concebido como um verdadeiro santo. Em nome dos apelos capitalistas, a exploração em função do mito se justifica como uma faceta em que os fins justificam os meios. Dessa forma, medalhas, loterias, amuletos, santos e outros objetos são comercializados em função de uma engrenagem arquitetada para garantir a manutenção da elite local no poder.

Quando ocorre o retorno do herói, no Terceiro Quadro, em virtude da anistia, sobrevém a possibilidade de derrocada do lugar pelo fato do desmoronamento da exploração do mito. Assim, evidencia-se que um homem pode ser mais útil morto do que vivo, como revela o desfecho marcado pela tragicidade no qual Matilde negocia sua permanência no local com Chico Manga e assassina o pro- 
tagonista:

MATILDE: Isso é com o Major. Vamos levar ele pro quarto. Assim ele dorme e a coisa fica mais fácil. Ouve-se o ruído de uma janela estilhaçada.

RAPARIGA 1: Que é isso?

RAPARIGA 2: (Entra correndo, assustada.) São elas! As beatas!

Novos ruídos, a casa está sendo apedrejada.

MATILDE: De novo!

RAPARIGA 2: Desta vez são mais de vinte! E o Vigário vem com elas!

MATILDE: É um Vigário do Cão!

RAPARIGA 1: Oh, padre excomungado!

MATILDE: (Xingando, pra fora). Chupadoras de hóstia! Beatas duma figa!

RAPARIGA 1: (Grita também.). Estão é com falta de homem! Venham pra cá que eu arranjo um pra cada uma!

MATILDE: Vão jogar pedra na mãe! Uma pedra arrebenta uma vidraça e vem cair dentro da sala, junto de Cabo Jorge.

RAPARIGA 2: Quase caiu na cabeça dele!

RAPARIGA 1: (Arma-se com uma garrafa.) Que entre uma dessas beatas aqui pra ver o que the acontece.

MATILDE: Espera... tenho uma ideia... (Apanha o estilhaço de vidro. Ri. Volta à janela). Isso, atirem mais pedras! Quebrem tudo, que eu tenho quem pague. (Volta para junto de Roque com o vidro na mão. Rapariga 2, cobre o rosto com as mãos) (GOMES, 2015, p. 141-142).

Ao analisar o protagonista da peça de Dias Gomes, o crítico Anatol Rosenfeld (1996) encara a personagem como um anti-herói, uma vez que não foi herói no campo de batalha como todos pensavam, mas foi cultuado na sua cidade natal, ganhando as honrarias que o elevam ao plano mítico. Sua ascensão como figura heroica está atrelada ao desenvolvimento econômico da cidade e ao enriquecimento de personalidades arrivistas exploradoras do mito da fé. De volta à cidade rebatizada com o seu nome, Roque constitui uma ameaça para a engrenagem que alimenta a farsa. 
Avançando nas tessituras acerca da personagem, o estudioso Igor Sacramento (2012), de maneira oposta a Rosenfeld (1996), prefere enquadrar a personagem como um herói negativo, uma vez que cabo Jorge promove uma grande tensão entre o drama e o épico brechtiano. O autor explica que as diferenças entre o anti-herói e o herói negativo são bastantes sutis. Para Sacramento (2012), o anti-herói age movido a ações que não são associadas ao bem, tendo como exemplo também aquele personagem sem as qualidades tradicionalmente associadas a um herói (astúcia, dignidade, pureza, integridade).

Sacramento (2012) define o herói negativo como aquele moldado sem a presença de condutas celebradas pela sociedade. Por tal motivo, as personagens que se enquadram nessa característica apresentam estranhamento e causam repulsão. "Em Dias Gomes, [...] a construção dos heróis negativos é extremamente ambígua, provocando distanciamento e identificação" (SACRAMENTO, 2012, p. 251).

Ampliando um pouco mais a explanação acerca das diferenças entre o anti-herói e o herói negativo, pode-se dizer que o anti-herói apresenta como um traço bastante característico: sua apresentação inicial de forma humanizada. Seu desfecho é trágico, sobretudo pelo fato dele ser derrotado e por apresentar defeitos estruturais responsáveis pela identificação com o público. Esse tipo de protagonista sempre luta contra outros heróis por carregar motivações pessoais.

\section{CONSIDERAÇÕES FINAIS}

A peça O Berço do Herói revela a postura de um intelectual inquieto, característica, aliás, recorrente no conjunto da obra de Dias Gomes. Esse teatro engajado, gestado no conturbado contexto político de 1963, traduz uma efervescência cultural em que a estratégia do emprego da tragicidade e do herói negativo apresentam a função de representar o contexto problemático e ambivalente do país. Assim, é importante destacar que a peça serviu como tradução de um momento histórico bastante ambivalente, revelando uma grande inquietação do autor diante do dilema enfrentado pelo país. É devido a essa singularidade que Rosenfeld 
(1996) atribui a Dias Gomes o rótulo de "rebelde sadio", justamente pelo fato de o dramaturgo escrever obras marcadas pelo engajamento.

O leitor deve ter em mente que até mesmo a tragicidade da peça tem como fundamento preservar a existência da exploração do mito da fé responsável pela sustentação da cidade. Ademais, o protagonista não se sacrifica. O leitor não espera que ele seja morto em uma casa de prostituição numa cena totalmente grotesca. Ademais, esse herói não é íntegro, puro, tampouco tem uma trajetória que o aproxime do típico herói maniqueísta. Assim, Cabo Jorge se caracteriza pelo traço da ambivalência ao passo que tenta lutar por uma espécie de liberdade constitucional em uma estrutura solidificada com bases forjadas, mas, por outro lado, é o responsável direto pela ascensão do mito.

Ainda com relação ao protagonista, pode-se acrescentar que ele não tem um grande projeto. Ressurge depois de 17 anos para causar a revolta do grupo dominante e alimentar a tensão acerca da possível desconstrução do mito. Ele é simples, sem profundidade. Age com propósitos comuns, sem idealizações ou grandes narrativas. Seu amoralismo e covardia foram responsáveis diretos, como já assinalado, pelo surgimento do mito da exploração da fé. A partir do momento em que retorna para sua cidade natal, ele, simplesmente, infiltra-se no rol de personagens, sendo apenas mais um dentre vários tipificados como ambivalentes, até que é assassinado como forma de manutenção da estrutura que move a cidade.

\section{REFERÊNCIAS}

BAKHTIN, Mikhail. A Cultura Popular na Idade Média e no Renascimento: o contexto de François Rabelais. Trad. Yara Frateschi Vieira. São Paulo: HUCITEC, 2013.

COSTA, Iná Camargo. Dias Gomes - um dramaturgo nacional popular. São Paulo: Editora Unesp, 2017.

FRANCIS, Paulo. Prefácio de O Berço do Herói. In: GOMES, Dias. O Berço do Herói. $6^{\mathrm{a}}$ ed. Rio de Janeiro: Bertrand, 2015. p. 7- 10. 
GOMES, Dias. O Berço do Herói e as armas do Carlos. In: GOMES, Dias. Roque Santeiro ou O Berço do Herói. Rio de Janeiro: Nova Fronteira, 2015.

GOMES, Dias. O Berço do Herói. 6ª ed. Rio de Janeiro: Bertrand, 2015.

GOMES, Dias. Roque Santeiro ou O Berço do Herói. Rio de Janeiro: Nova Fronteira, 2015.

RESENDE, Beatriz. Dias Gomes, o dramaturgo do povo. Caderno Globo Universidade, n. 3. Rio de Janeiro, Globo, 2013, p.10- 15.

ROSENFELD, Anatol. O Mito e o herói no moderno teatro brasileiro. São Paulo: Perspectiva, 1996.

SACRAMENTO, Igor. Entre o dramático e o épico: O herói negativo e as hibridizações estéticas na teledramaturgia de Dias Gomes nos anos 1970. Revista Eletrônica Literatura e Autoritarismo, Rio Grande do Sul, p. 247-271, mai. 2012. 
do' $10.48209 / 978-65-89949-16-5$
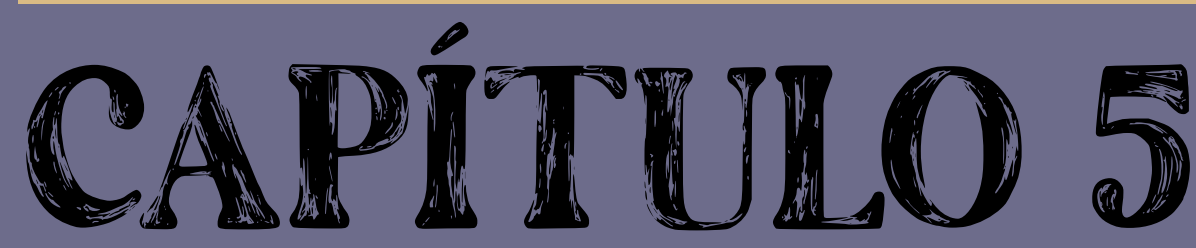

\section{ESCRITA COMO PERFORMANCE:} FRAGMENTOS E SINTESES

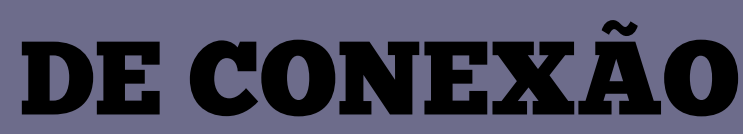

Waldenilson Teixeira Ramos 


\section{INTRODUÇÃO}

Neste capítulo realizarei um exercício de metalinguagem, uma meditação a respeito da escrita, em busca de realizar uma aposta epistemológica que, por consequência, também é política: visa-se tecer uma reflexão a respeito das múltiplas facetas em potencial de uma escrita, olhar para o ato de escrever como performance da multiplicidade. Para tanto, será colocada sob escopo de análise a escrita ficcional e o que ela pode produzir na perspectiva da ontologia. Intrínseco a esta reflexão se encontra um projeto de livro que, até o presente momento, pretende-se intitular Fragmentariedades de sentidos para novas conexões, projeto de suma importância aqui, pois é ele que fornece os materiais empíricos deste trabalho. Diante disso, observou-se a escrita como um trabalho de infinito processo emancipatório, interminável, complexo e múltiplo de retomadas e de invenções. Nesta aposta teórico-metodológica, é razoável admitir a influência de uma multidão: muitas pessoas vistas por mim, muitas pessoas que experimentei como traço do campo relacional e aquelas outras que viveram e vivem em mim memórias e afetos. Neste trabalho me aproximo e me entendo capturado pela seguinte fala: "Escrevemos $O$ anti-Édipo a dois. Como cada um de nós era vários, já era muita gente" (DELEUZE, 2013, p. 11). Assim, é notório que, no gesto da tecnologia escrita, pode-se não escrever com um par ao lado, mas escrever a sós - o escritor e uma multidão. Nesse âmbito múltiplo, faço e percebo este trabalho: fragmentado, marcado, temporizado, encarnado e impregnado de sentidos.

Usufruindo de minha própria experiência com a escrita, faço da experimentação em meu corpo o escopo empírico e a aposta metodológica presente nas linhas e entrelinhas desta escrita. Portanto, muitas admissões se fazem centrais, pois evidenciam um exercício meditativo e de atenção aos sentidos e afecções presentificadas em corpo intensivo (DELEUZE; GUATTARI, 2011). Sendo assim, expresso que tudo que escrevo é meu e sou eu, na mesma medida em que vai para além de mim mesmo. Não pretendo realizar uma escrita do meu $\mathrm{Eu}$, muito pelo contrário, encontro ficcionado em minha carne aquilo que é comum aos sujeitos modernos - efeitos de verdades (FOUCAULT, 1981/2016). Os fragmentos 
produzidos pelo ato de escrever são consonantes à produção maquínica do presente, isto é, meu corpo é intermediário do mundo externo - campo social, território, relações pessoais e culturais, modalidades de política que me constituem - e meu processo de invenção de si - produção de subjetivação, linhas flexíveis e de fuga. Dessa forma, aposta-se que todo escritor dá notoriedade à ontológica do comum (MOTTA; MOZIGUCHI, 2019) - um corpo como mais uma máquina agenciada à máquina social que tem os sentidos como resíduo/efeito desta operação. Por fim, afirmo que este processo só é possível no reconhecimento da multidão, multidão esta que marca os encontros que nos trouxeram até aqui.

No encontro daquilo que é experienciado, sentido e marcado, onde cada fragmentariedade se faz, a escrita assume a performance da multiplicidade. Quando se pergunta qual é a direção e o destino da escrita, uma das respostas possíveis é: em direção ao devir, concomitantemente às sínteses conjuntivas realizando cortes e aberturas, não se fechando a nenhum dos dois. Na verdade, a escrita segue no vetor de toda diferença: ela é multiplicidade (DELEUZE, 1997).

\section{DESENVOLVIMENTO}

No que tange à construção narrativa de humanidade, a escrita tomou tamanha notoriedade que, por muito tempo, levou o discurso epistemológico da história a uma dicotomia entre o período pré-histórico e os demais grandes períodos. Isso se evidencia ao compreendermos que aquilo que é visto como Pré-história é, na verdade, o percurso narrativo da história humana cindido pela evidência da escrita, ou seja, Pré-história por muito tempo foi escopo epistêmico anterior à escrita. Eminentemente, essa visão foi profundamente criticada pelos historiadores da modernidade, e na atualidade essa crítica se encontra bem difundida em muitas revistas, por exemplo, de educação básica:

O termo Pré-história foi criado em 1851 e pretendia designar o período da vida da espécie humana anterior à invenção da escrita. A história seria estudada, portanto, a partir do momento em que surgiram os primeiros documentos escritos. Essa ideia é hoje muito criticada, afinal, os humanos que não sabiam escrever também têm história. Eles viviam, comiam, faziam objetos, se comunicavam. Como já sabemos, não é preciso o documento escrito para a pesquisa histórica. A cultura material também 
é fonte importante para o trabalho do historiador (DIVISÕES..., 20092021).

Para além das discussões epistemológicas da história moderna, o que interessa neste trabalho é a notoriedade dos efeitos, as cristalizações e as forças políticas que a escrita pode alcançar, efeitos subjetivantes grandiosos e presentes no discurso da humanidade.

O ato de escrever certamente é um movimento de multidão. Desde muito cedo, como membros de uma grande comunidade capitalista, muitos de nós são convocados a praticar e desenvolver a tecnologia da escrita, e aqueles que não estão envolvidos neste suposto convite são vistos como à margem da lógica predominante de nossa sociedade. A Constituição Brasileira de 1988 (BRASIL, 1998), no Art. 205, e a Organização das Nações Unidas (ONU), no Art. 26 da Declaração Universal dos Direitos Humanos (UNICEF, 1948) reiteram o direito universal à educação e, com ele, a aprendizagem de ler e escrever. Esse seria o direito fundamental e primordial de todo e qualquer ser humano. Portanto, o exercício de escrever se apresenta fortemente como elemento de inclusão e dignidade humana, e, como todo e qualquer processo de aprendizagem e compartiIhamento, a escrita segue essa força que necessariamente perpassa uma constituição ontológica de si e do comum. Espaços comuns de aprendizagem são também, necessariamente, o ambiente de constituição de si que nos atravessa e impregna nossas existências. A escrita forja esses grandes laços de nossa ontologia, especialmente quando temos a oportunidade de participar desse ambiente, quando não somos excluídos pelas políticas de exceção do Estado.

Esse processo de travessia e constituição de si ganha evidência ao reconhecermos as escolas, as famílias e todo e qualquer espaço pedagógico que submete um sujeito aos signos e códigos linguísticos de uma comunidade, como espaço de inserção na vida capitalista. A escrita é a tecnologia que inscreve sobre uma superfície a língua e a linguagem compartilhada por uma comunidade, ela é a manifestação, em uma série de signos, da constituição daquele que opera o procedimento do escrever; escrever é marcar em uma superfície parte da pro- 
dução de uma subjetividade, e faz com que uma força subjetivante passe a uma matéria ativa, matéria vivida. Deleuze (2013) percebeu e fez ver esse fenômeno ontológico do comum ao defender, na obra Conversações, a multidão presente em sua escrita, assim como fez quando escreveu com Guattari $O$ anti-édipo (DELEUZE; GUATTARI, 2011).

Imediatamente fica evidente que a escrita é a marca em signos de uma multidão presente em nossa subjetividade. Garantir o direito de apreender a escrita é, necessariamente, garantir a possibilidade de expressamos a constituição de uma multidão em nós, lugares que passamos, comunidade que compartilhamos, a língua e a linguagem que nos dominam e nos perpassam, discursos e verdades que se nos apresentam - a escrita é a expressão material das forças e das linhas segmentares que nos tecem. O gesto tecnológico da escrita, quando dentro das possibilidades inventivas, faz fluir a força imanente da vida, na mesma medida em que faz da matéria vivível - força que lateja no corpo que escreve e forja uma força intensiva com outro corpo que, ao ler o que se fez escrito, se agencia por este. Deleuze argumenta que o ato escrito é devir - abertura, um vir a ser, força que se desloca de um corpo -, e certamente é, em toda veracidade da vida, um inacabamento do que pode tornar-se, ao mesmo tempo que não visa à completude de um fim. Em Crítica e clínica, Deleuze (1997, p. 11) diz:

Escrever é um caso de devir, sempre inacabado, sempre em via de fazer-se, e que extravasa qualquer matéria vivível ou vivida. É um processo, ou seja, uma passagem da Vida que atravessa o vivível e o vivido. A escrita é inseparável do devir: ao escrever, estamos num devir-mulher, num devir-animal ou vegetal, num devir-molécula, até num devir-imperceptível.

É nesse mesmo cenário que o ator político escritor realiza a sua performance aberta no grande ambiente teatral do mundo, sempre produzindo e sendo produzido por afecções da matéria vivida. Assim sendo, a escrita cada vez mais evidencia seu caráter duplo vetorial, pois escreve-se sempre em um mundo da partilha de uma língua comum - podendo ser um gesto para si e/ou para o outro. Deleuze (1997, p. 13) fortalece essa tese ao dissertar: "Por isso o escritor, enquanto tal, não é doente, mas antes médico, médico de si próprio e do mundo." 
Analogamente, Proust (2017), na obra Em Busca do Tempo Perdido, evidencia bem essa operação ao dissertar que o trabalho do escritor é simplesmente uma espécie de instrumento óptico oferecido ao leitor para lhe permitir distinguir o que, sem o livro, ele talvez nunca fosse vivenciar em si mesmo. Em seu estudo sobre a obra de Proust, Botton (2011, p. 25) tece o seguinte comentário:

Na verdade, todo leitor, enquanto está lendo, é o leitor do seu próprio eu. O trabalho do escritor é simplesmente uma espécie de instrumento óptico oferecido ao leitor para lhe permitir distinguir o que, sem o livro, ele talvez nunca fosse vivenciar em si mesmo. E o reconhecimento em si próprio, por parte do leitor, daquilo que o livro diz é a prova da sua veracidade.

Assim, diante de tudo o que a escrita pode assumir e da multiplicidade vetorial de seus efeitos para a produção de subjetividade, que nela se faz latente, é inegável que ela opera para além da pura e simples comunicação, ela é máquina operadora também no campo ontológico. A narrativa do percurso da humanidade se fez durante muito tempo esquadrinhada pela presentificação ou pela suposta ausência de ato escrito - algo tão presente a uma camada epistêmica das ciências humanas que possibilitou a delimitação de dois períodos: o da história e o de antes da história (Pré-história). A escrita é uma tecnologia tão fundamental à inclusão em nossa comunidade que o não acesso aos ambientes pedagógicos pode significar viver-se à margem da lógica predominante de nossa sociedade capitalista. A escrita é uma força orquestral que atravessa uma multidão de nossas relações e a multidão dentro de cada um de nós - nossas experiências, afecções e as políticas que forjam nossa constituição -, e, por isso, o escritor é o ator político de performance, uma atuação em um cenário medicinal/terapêutico de si e de quem o lê. A escrita é essa tecnologia tão fascinante e tão subjetiva à humanidade, e tal tecnologia sempre está em suas vias inventivas, em sua vertente criadora; ela é muito maior que a língua que a possibilita e sempre é maior do que o próprio escritor. Portanto, diante das multiplicidades que apresenta e dos efeitos que produz, seria impossível abarcar neste estudo todas as possibilidades da escrita. Assumimos, então, com Deleuze (1997), que a escrita é a performance da alma em matéria ativa; a sua grandiosidade é matéria ativa que performatiza a multiplicidade. 


\section{RESULTADOS E DISCUSSÃO}

Daqui em diante, dado o caráter grandioso e performático da escrita, voltaremos nossa atenção para os seus processos e efeitos, mais especificamente para o que a escrita tem a dizer de quem escreve e o momento em que um corpo escritor nela é inserido. Em um exercício de análise de mim mesmo, se fez caro um olhar atento ao meu eu e à multidão que há em mim, processo de escrita. Este é o objeto central deste trabalho, compartilhar reflexões que são frutos de uma série de discussões abordadas no grupo de pesquisa de iniciação científica "Poéticas e Políticas de Transmissibilidade em Psicologia Social”. O núcleo pertence ao Departamento de Psicologia da Universidade Federal Fluminense (UFF), do qual eu faço parte. O grupo detém-se, no atual momento, à investigação da escrita como processo de subjetivação. Com base nos estudos teóricos, perpassando as noções de "escrita de si" de Michel Foucault (2001) e de "escrevivência" de Conceição Evaristo (2019), produções textuais emergiram. Nesse contexto, os microcontos ${ }^{5}$, poesias ${ }^{6}$ ou quaisquer outras produções forjadas pelas minhas mãos se evidenciaram como forças intensivas que me constituem e expressam as sínteses que residem em mim. Dentre as muitas reflexões que alegorizam os processos ontológicos de criação de si e de libertação, se inaugurou a apresentação dos diversos sentidos produzidos pela direção da imagem do espelho.

O espelho em sua inércia tudo reflete - replica o engano, inverte o que the aparece. Preso a uma parede ou mobília, fica do jeito que o humano quer, imita o engano, reitera a imagem do homem e da mulher. É prisioneiro de um exercício do qual não tem ciência; todavia, segue-o à risca com todos os desvios. Não importa a sua posição, faz de todo ponto de vista uma visão - todo ponto de vista é a vista de um ponto. Por fim, no ponto em que lhe fixar, nunca dali sairá, a menos que alguma força o faça se deslocar.

5 Como exemplificação, mais adiante, ainda neste mesmo capítulo, apresentarei um microconto de minha autoria intitulado "Habitação".

6 Ainda no intuito de demonstrar material empírico, apresentarei a poesia "Checkpoints do genocídio: três 'pês"', também de minha autoria. 
Qualquer encontro fractal pode forjar seu apogeu libertino. Encontros com "golpes de martelo" (NIETZSCHE, 2001, p.101.) ou até mesmo uma brisa mansa podem quebrar seu sentido primário - origem de sua ficção. No momento em que o espelho vai de encontro à força do martelo de ferro ou à força de uma leve brisa que Ihe tira de seu ponto de fixação, suas sólidas codificações se quebram em cadeia, ao ir para o chão. Dele sobram apenas os restos, suas fragmentações. Este espelho, por via de seus fragmentos, pela primeira vez é livre para se dispersar, no sentido em que sua natureza física, a força vetorial que opera sobre cada fragmento, é de ordem totalmente imprevisível, inominável - assim como as linhas segmentares de fuga. Não se trata mais de um único espelho sólido, e o sentido de sua existência se renova, se forja. É belo pensar: todo esse evento adveio daquilo que Ihe possibilitou um novo expressar - expressão do que foi sentido... Um salto em direção a um elemento exterior, que aparentemente the destruiu, na verdade nele se fundiu.

A imagem do espelho preso na parede e que encontra uma força externa que o faz cair é uma das noções mais importantes destas reflexões e análise, pois através dela se busca dar notoriedade aos efeitos de cristalização de nossa subjetividade - códigos morais e contratos sociais que prescrevem e limitam tudo o que podemos vir a ser. A cena do espelho que vai ao chão e se despedaça é a metáfora dos encontros da vida que deslocam as posições duras e imóveis que os efeitos do poder produzem sobre todos e quaisquer corpos - códigos prescritivos que impregnam as representações de gênero e denunciam que a imagem homem/mulher é enganosa. Essa mesma força que faz deslocar um corpo é certamente uma posição no mundo, isto é, existir no mundo é, necessariamente, compreender-se sob a possibilidade de se haver com os encontros; todo encontro no mundo é uma força que marca, move, transforma. Os encontros mais poderosos se assemelham a golpes de martelo de ferro - um uso da filosofia nietzschiana -, já outros encontros parecem suaves e leves, se assemelham a uma brisa mansa - um uso da filosofia espinosana (DELEUZE, 2020). 
Todas essas forças vetorizam a queda ou possível redirecionamento do espelho e, encontrando a potência necessária, deslocam a imagem fixa que o reproduz, levando-o a um impacto em sua existência - e nesse exato momento algo novo se cria. $O$ espelho que se quebra ao sofrer o impacto de uma terceira força - a queda, o encontro ao chão —, essa que não é do espelho e nem do martelo ou da brisa que o deslocou, é a sua possibilidade inventiva - se colocar verdadeiramente no mundo, se fazer imundo, ir de encontro à diferença. O evento é nítido, o vidro se estilhaça e despende fragmentos para todas as direções, em vários sentidos possíveis. Em quais direções esses fragmentos irão?, pode-se perguntar, e a resposta é, necessariamente, "nunca se sabe". Essa é a força tão presente ao devir. A manifestação em estilhaços, fragmentos de si para todos os lados, este é o apogeu da existência criadora do espelho, em um movimento disruptivo com os códigos prescritivos de seu sentido originário. Os modos inventivos de seus fragmentos vetorizam-se a novos sentidos, direções totalmente sem destino ou de difícil localização.

As sínteses são tudo aquilo que o inconsciente maquínico produz (DELEUZE; GUATTARI, 2011). Ao inconsciente nada falta, tudo é produto de máquinas - por assim dizer, tudo que opera pelos cortes e fluxos são máquinas. Partindo da certeza de que cada encontro é único e de impossível repetição, é razoável assumir que, de cada encontro de nossa construção, só temos os restos, os fragmentos, as nossas produções - as sínteses. A máquina mão é produtora também de sínteses escritas. Quando o objeto parcial mão se acopla a uma máquina caneta, que, por fim, desliza inscrevendo sobre a máquina papel, uma corrente de energia perpassa cada acoplamento, deslizando e deixando marcas na última máquina. Tais marcas são uma produção desejante desses corpos maquínicos que se acoplaram. Doravante, uma máquina olho irá agenciar a máquina papel e, nesse momento, um novo fluxo passará a outro corpo máquina. Esse fenômeno certamente traz de novo o cenário que Marcel Proust (2017) outrora defendeu em tese: "O trabalho do escritor é simplesmente uma espécie de instrumento óptico oferecido ao leitor para lhe permitir distinguir o que, sem o livro, ele talvez nunca fosse vivenciar em si mesmo" (BOTTON, 2011, p. 25). Decerto, a tecnologia 
como resquício de uma máquina é produtora de subjetivação, e nessa operação "o sujeito é produzido como um resto, ao lado das máquinas desejantes, onde ele próprio se confunde com essa terceira máquina produtora e com a reconciliação residual que ela opera" (DELEUZE; GUATTARI, 2011, p. 32).

Como exercício de experimentação dessa escrita ontológica do comum e manifestação empírica dessa aposta teórica em torno da escrita, confeccionei o microconto seguinte:

\section{"Habitação"}

Interior

Ir à rua comprar um pão, nunca é só ir à rua comprar pão. O território se cruza e se amarra. Em cada volta, um laço. Você vai e volta, amarra o cadarço e faz um novo laço. Cidade pequena que faz de cada caminhada uma jornada nos afetos. E assim também se fazem os relacionamentos, refazendo os laços, encontrando com quem antes não se via mais. Ir comprar pão é fazer amarrar o cadarço do sapato, fazendo laços com as próprias mãos.

A caminhada no interior é extensa em seu comprimento: opa, seu Jorge! $E$ aí, Zé! Opa! A cada passo dado, centímetros. A cada esquina, metros. Em todo lugar, cumprimentos. Bom dia, dona Maria! Andar pelo bairro pequeno é se colocar na imensidão de uma rede. Rede que não se mede, mas em seu comprimento só há inúmeros cumprimentos!

A largura das ruas é estreita. Os becos, apertados. O comércio, concentrado. A rede é imensa e rizomática. Todos estão conectados, um efeito em cadeia. Sou Carol, filha do Jorge, neto da dona Maria. Maria, a esposa do Zé! Rede sequencial. Quantos metros tem essa rede? Mensura-se pelos cumprimentos, Opa, Zé! Como vai!?

\section{Exterior}

A cidade é aglomerada, cheia de fachadas, sempre lotada, vida acelerada. VIVO, CLARO, TIM, OI!!! Vida corrida, escorrida. Passa entre os dedos como se 
fosse líquida. Ninguém espera pela vida. Sinal verde, atravesse. Sinal vermelho, atravesse. Sinal amarelo, para que serve? Quem vai reparar? Parar, respirar? $\mathrm{Na}$ cidade? Sei lá... Tenho que trabalhar, estudar, me formar. No exterior do corpo extenso, o mundo roda, gira e acontece. Ao mesmo tempo que o corpo envelhece, emagrece, dizem que cresce.

- Dois caras na garupa bolados

- Quê?

- Olha, cuidado!

- Como?

- Ah, pronto... foi roubado.

(Um tempo e uma caminhada se passa)

- Cheguei ao meu apartamento. Vou pegar o elevador. Sexto andar, por favor. - Do lado, um homem parado, desconfiado.

- O que esse cara tava fazendo do lado de fora do prédio? iii... Essa porra tá de treta, quer ver? - Assim pensa o homem que chega do trabalho meio machucado, ralado, cansado.

- E ainda não entendi o porquê desse cara do meu lado...

- Sexto andar, senhor - diz o assessor.

Um sai e o outro vai atrás. Aperta o passo, anda mais rápido como se fosse correr. Se sente como se tivesse em um programa de TV. Põe a mão na maçaneta, treme, meio que perdendo a cabeça. E o outro... nem o vê. Mas segue caminhando em sua direção, mexendo em alguma coisa em sua mão.

- Caralho, tá trancado! Puta que pariu!, tá amarrado!

E o outro chega perto e passa direto, quase que discreto. Entra na porta ao 
lado. O medroso respira, retoma a consciência. Finalmente entendeu que aquele jubileu é apenas mais um vizinho de anos que ele nunca conheceu. Entra em seu apartamento e senta-se em frente à TV, recomeça a ver a representação de um viver.

- Porra... essa vida mansa é tudo que eu gostaria de ter...

Nesse âmbito múltiplo, faço e percebo este trabalho. Fragmentado, marcado, temporizado, encarnado e impregnado de sentidos. Tudo aqui escrito é meu e sou eu. No entanto, não pretendo realizar uma escrita do meu Eu ou de minha história pessoal, muito pelo contrário, encontro ficcionado em minha carne aquilo que é comum ao sujeito moderno. Antes de mais nada, compreendo este escrito como uma obra política. E, para que se possa apostar neste trabalho politicamente, se faz necessário um direcionamento às teses de Walter Benjamin (2012), em um recorte da compreensão do que é experiência e pobreza. Nessa relação, aposto na notoriedade ontológica do comum. Enfim, trata-se de um processo que só é possível no reconhecimento da multidão, a mesma que marca os encontros que me trouxeram até aqui, os quais, por sua vez, me marcam enquanto sujeito. É sob essa direção ético-metodológica que se define a análise metalinguística deste capítulo.

Foi esse ato da escrita como manifestação da uma multidão em nossa constituição subjetiva que Conceição Evaristo (2019) chamou de "escrevivência”. A autora deixa explícita a encruzilhada entre os territórios, as memórias e a multidão que habitam nela, e é a escrita que assume a função de instrumento materializador de sua estilística existencial. Não à toa, ela declara:

Escrevo como uma homenagem póstuma à Vó Rita, que dormia embolada com ela, a ela que nunca consegui ver plenamente, aos bêbados, às putas, aos malandros, às crianças vadias que habitam os becos de minha memória. [...] Homens, mulheres, crianças que se amontoaram dentro de mim, como amontoados eram os barracos de minha favela (EVARISTO, 2019, p. 17). 
Nessa mesma direção "escrevivida" - manifestação ontológica do comum em ato escrito -, atento àquilo que é sentido em meu próprio corpo, compus a seguinte poesia:

"Checkpoints do genocídio: três 'pês"”

Na noite escura, preta

Pele marcada à caneta

Na favela mais uma perda

É polícia, corre! É treta!

Preto

que morre

Sangue que escorre

Apenas uma faceta

Mata-mata de roleta

A vida no morro é preta

Não importa a ideologia da camiseta

Dinheiro na maleta?

Só pra quem tá de terno e prancheta

Pobre

que diariamente vai à luta

Dia, tarde, noite e madruga

Já nem liga para o estado da blusa

Quer mais não ser morto pelos trutas

Levanta, vagabunda

Quero fuder sua bunda 
Assim ouve a prostituta

Prostituta

expurgada sem burca

Um corpo que madruga

Calada que machuca

Sabe que é mulher madura

Umas por prazer

E outras por não conseguir ler

Já não é mais possível saber

Quem vai pra conhecer

Ou que tá na luta pra ter o que comer

Julgamento certamente vão ter

Mas, no fim, só elas vão saber

Se nesta noite vão sobreviver

No terraço em Ipanema

A noite vai ser pipoca no cinema

Todo dia se repete a mesma lenda

História de quem conhece bem o esquema

Gritaria no portão:

- LEVANTA A MÃO, VACILÃO!

JÁ FALEI, VAI PRO CHÃO!

Um tapão... 
Um bicudão...

Um socão...

Morre um ladrão...

Notícia de horror e terror

"Nessa madrugada morre um trabalhador"

Bala perdida o acertou

No velório

As amigas se despedem da Wanessa

Travesti que estava voltando da peleja

Preta, pobre e prostituta

Morta em meio à luta

No início de 2020,100\% dos mortos pela força policial em Cachoeiras de Macacu, Guapimirim, Petrópolis, Rio Bonito e Seropédica eram negros (FERREIRA, 2020).

\section{CONCLUSÃO}

Um dos resultados alcançados na experiência escrita e no processo de construção do livro Fragmentariedades de sentidos para novas conexões foi a observância do escrever como escopo expressivo de um aglomerado de sentidos, uma manifestação da estilística existencial e ontológica de quem escreve. Os fragmentos ali presentes estão consonantes à produção do regime vigente, isto é, meu corpo é intermediário do mundo externo - campo social, relações pessoais e culturais, modalidades de política que me constituem - e meu processo de invenção de mim - força de subjetivação. Nos exercícios meditativos sobre a escrita, compartilhados com o grupo de iniciação científica acima citado, 
constatamos um corpo intensivo entulhado de sentimentos e cacos do mundo. Como fruto desta operação de corpo no mundo, a escrita se apresenta como os restos que se conectam a outros, sempre desejantes de novas conexões. Portanto, se a escrita está sempre em vias desejantes de novas conexões, faz jus o seu compartilhamento, o que significa compartilhar histórias e sentidos que não são nossos, mas que se impregnaram em nós em contato com o comum do mundo. Está aí, então, uma prática clínico-estético-política, uma escrita que performa a existência de uma multidão ontológica.

\section{REFERÊNCIAS}

BENJAMIN, Walter. Magia e técnica, arte e política: ensaios sobre literatura e história da cultura. 8. ed. Tradução de Sérgio Paulo Rouanet. São Paulo: Brasiliense, 2012. v. 1. Obras escolhidas.

BOTTON, Alain de. Como Proust pode mudar sua vida. Rio de Janeiro: Intrínseca, 2011.

BRASIL. Constituição (1988). Constituição da República Federativa do Brasil. Brasília, DF: Senado Federal, 1988.

DELEUZE, Gilles. Crítica e clínica. 1. ed. Editora 34, 1997.

DELEUZE, Gilles. Conversações. 3. ed. Editora 34, 2013.

DELEUZE, Gilles. O que é filosofia? 3. ed. Editora 34, 2020.

DELEUZE, Gilles; GUATTARI, Félix. O anti-édipo. 2. ed. Editora 34, 2011.

DIVISÕES / Períodos da História. Só História. Virtuous Tecnologia da Informação, 2009-2021. Disponível em: <https://www.sohistoria.com.br/ef2/periodos/>. Acesso em: 25 maio 2021.

EVARISTO, Conceição. Becos da memória. 3. ed. Rio de Janeiro: Pallas, 2019.

FERREIRA, Lucas. Mapa indica que $81 \%$ dos mortos em operações no Rio são negros. R7 - Rio de Janeiro. 16 jul. 2020. Disponível em: <https://noticias.r7. com/rio-de-janeiro/mapa-indica-que-81-dos-mortos-em-operacoes-no-rio-sao-negros-16072020>. Acesso em: 18 maio 2021. 
FOUCAULT, Michel. História da sexualidade: o uso dos prazeres. Rio de Janeiro: Graal, 2001. v. 2.

FOUCAULT, Michel. Subjetividade e verdade (1981). São Paulo: Martins Fontes, 2016.

MOTTA, Clara Urzedo Rocha; MIZOGUCHI, Danichi Hausen. As ontologias do comum e a psicologia social: fragmentos de uma aposta. Psicologia \& Sociedade [online]. 2019, v. 31, e188475. <https://doi.org/10.1590/1807-0310/2019v31188475>.

NIETZSCHE, Friedrich Wilhelm. O Crepúsculo Dos Ídolos. 1. ed. Hemus, 2001.

PROUST, Marcel. Em busca do tempo perdido. 3. ed. Rio de Janeiro: Nova Fronteira, 2017.

UNICEF - Fundo das Nações Unidas para a Infância. Declaração Universal dos Direitos Humanos (1948). Disponível em: <https://www.unicef.org/brazil/declaracao-universal-dos-direitos-humanos>. Acesso em: 18 ago. 2021. 
doi $10.48209 / 978-65-89949-16-6$

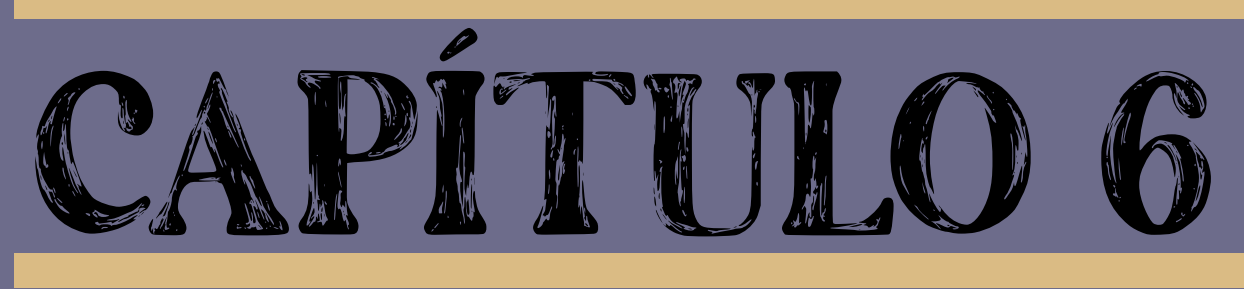

\section{O FANTÁSTICO EM RUBIÃO: PROPOSTA PARA O ENSINO DE LITERATURA}

Luciana Morais da Silva Karla Menezes Lopes Niels 


\section{INTRODUÇÃO}

Para nós, em pleno século XXI, pode parecer natural o ensino de língua e literatura na escola, entrementes, conforme atesta Magda Soares (2004), Clécio Bunzen (2011) e Ana Cristina Coutinho Viegas (2014), a disciplina Língua Portuguesa, bem como a disciplina Literatura são deveras recentes, remontando de fins do século XIX. Ainda, sobre o ensino das duas disciplinas - hoje apenas uma - Soares considera que a ampliação do ensino, na época de nossa ditadura militar, resultou em uma consequente precarização do ensino, haja vista "a necessidade de recrutamento mais amplo e menos seletivo de professores [...] e precárias condições de trabalho" (SOARES, 2004, p. 167). Com isso, os professores passaram a transferir ao livro didático a responsabilidade da preparação de aulas e exercícios, reservando pouco tempo à leitura e análise de textos literários. Hoje, infelizmente, observa-se grande parte de nossos professores da educação básica permanecem presos ao livro didático, usando como uma espécie de "Bíblia" para guiar seus passos (SOARES, 2004).

Por sua vez, os livros didáticos apresentam uma estrutura de ensino, tanto em língua como em literatura, ainda hoje engessada e descontextualizada. No caso da primeira, trabalhando a gramática normativa a partir de frases desconexas; no caso da segunda, valorando a história literária em detrimento ao próprio texto literário. Em contrapartida, a própria história da literatura brasileira guarda em si muitos autores e escritos esquecidos, assim como muita história guardada nas ficções perdidas no tempo. Ademais, por vezes, a pretensão de leitura do professor e o caminho percorrido pelo aluno divergem, o que acaba desestimulando o discente pela dificuldade em acessar o texto literário da maneira que the é requerido

Como é possível perceber o ensino de literatura requer a apreensão por parte do professor das novas demandas escolares, contribuindo para estabelecer com o aluno um ambiente de construção de conhecimento e, também por isso, um ensino focado na criatividade. Assim, um processo de ensino-apren- 
dizagem que incentive um olhar para a própria literatura brasileira, percebendo como a magia, o insólito, o fantástico demonstra-se como eixos significativos para o desenvolvimento dos alunos é essencial para a ampliação do interesse e do acesso pela leitura.

Trazemos como exemplo Murilo Rubião, autor nascido em Carmo de Minas, que por anos foi publicado apenas em seu estado natal, sem sair de sua vida comum. Tanto que o escritor ficou conhecido como aquele que "escreveu adiantado e publicou escondido" (ZAGURY apud WERNECK, 1987, p. 12). Entrementes, sua produção ficcional vem sendo cada vez mais estudada no campo dos estudos da literatura fantástica, assumindo "uma importância cada vez maior na literatura brasileira contemporânea" (SCHWARTZ, 1981, p. 1). A escrita rubiana poderia, nesse contexto, ser incluída em salas de aula, como fonte de inspiração para muitos alunos brasileiros. O mundo transcendente, inesperado e desafiador elaborado pelo autor pode, por exemplo, permitir aos alunos ampliar sua criatividade, especialmente ao explorar elementos comuns do quotidiano.

O reconhecimento dado ao autor de um conjunto de contos com claro matiz fantástico permitiu um devir ainda mais fortuito para as literaturas de cunho insólito. Desse modo, escritores e escritos que passaram anos não sendo nem ao menos mencionados, começaram a encontrar certa valorização, seja na academia, seja na leitura do público mais jovem. Cumpre ressaltar, no entanto, que o efeito do fenômeno de leitura deste tipo de literatura decorre do fato de ter crescido o nicho de mercado em torno da produção de materiais sobre magia, bruxaria e sobrenaturalidade, presentes no imaginário contemporâneo, a exemplo dos inúmeros HQ's, mangás, jogos de RPG e séries em streaming que cada vez mais tem explorado temáticas como essas, a exemplo das editoras como a Darkside Books, a Devir editora e a Jambô Editora, especializadas em publicações deste tipo.

No entanto, mesmo com o contínuo resgate da literatura de cunho fantástico que tem se dado na academia desde fins do século passado, bem como em outros espaços, os livros didáticos do Programa Nacional do Livro Didático 
- PNLD - ainda adotam práticas oitocentistas de ensino de literatura, apresentando-a de maneira linear e conforme as primeiras historiografias da literatura nacional. Com isso, excluem-se grande parte dos textos que, em algum momento, foi entendida pela crítica como "menor", a saber, a literatura escrita por mulheres, a literatura afrodescendente e ameríndia, a literatura de cunho fantástico ${ }^{7}$ - gótico, fantástico, maravilhoso, fantasia, romance policial, realismo-mágico, horror, etc. Mesmo naqueles em que se reserva algum espaço para falar-se sobre este tipo de literatura, trata-se de um espaço diminuto e de uma abordagem que não valora as características intrínsecas do texto literário e menos ainda o texto em si, em sua integralidade, pois a disposição do público juvenil para essa literatura é maior. Vale ainda ressaltar que os jovens leitores, embebidos pelos mistérios e aventuras presentes em filmes e séries demonstra uma maior predisposição para a leitura de obras cuja a temática gire em torno do insólito, do inesperado, do surpreendente. Pois, como bem observa Regina Micheli:

As narrativas insólitas fraturam o senso comum e o cotidiano, promovendo a alteridade e a abertura ao inusitado, instaurando o novo. Esses traços por si sós já justificariam a adoção desse tipo de literatura em atividades escolares, que carecem de constante renovação e devem primar pela criatividade. (MICHELLI, 2012, p.52)

Por isso, pretende-se, por meio da presente discussão, refletir acerca do ensino de literatura, bem como oferecer possíveis abordagens da leitura em sala de aula, a partir da literatura de cunho fantástico, outrora (quiçá ainda hoje) relegados ao esquecimento, porém importantes aliados no desafio de apreender e interrogar alunos. Assim, será com base na percepção da linguagem literária de Murilo Rubião que trataremos do ensino-aprendizagem em sala de aula, percebendo, a partir do texto literário, as possibilidades de interpretação via linguagem literária, bem como suas relações contextuais e extratextuais.

$7 \quad$ Apesar de não ser nossa intenção neste texto circunscrever o fantástico, cumpre ressalvar que o entendemos aqui como modo (CERESANI, 2006; FURTADO, 2012; GAMA-KHALIL, 2019), isto é, como um arquigênero que abarca os mais diversos gêneros em que se verifica a temática metaempírica (FURTADO, 2012). 


\section{O FANTÁSTICO}

Tratou-se aqui de termos talvez não reconhecidos pelo público mais distanciado dos Estudos Literários ou mesmo aquele não ligado aos estudos acerca da Literatura Fantástica. Por isso, faz-se mister uma pequena contextualização. $O$ estudo acerca das Literaturas Fantásticas revela a ideia de um mundo insólito e amedrontador, contudo como bem define Tzvetan Todorov:

Dans un monde qui est bien le nôtre, celui que nous connaissons, se produit un événement qui ne peut s'expliquer par les lois de ce même monde familier. Celui qui perçoit l'événement doit opter pour l'une des deux solutions possibles: ou bien il s'agit d'une illusion des sens, d'un produit de l'imagination et les lois du monde restent alors ce qu'elles sont; ou bien l'événement a véritablement eu lieu, il est partie intégrante de la réalité, mais alors cette réalité est régie par des lois inconnues de nous. ${ }^{8}$ (TODOROV, 1970, p. 29)

Seja no Brasil, seja na Europa, mais especificamente em Portugal, a escrita da literatura fantástica esteve mesclada com uma ideia de literatura de fuga e evasão, próprio das culturas de massa, sendo assim, rechaçada como somenos uma literatura de leitura rápida voltada para o entretenimento. O que infelizmente ainda no século XXI permanece, ao menos no caso brasileiro, haja vista a divisão de categorias do prêmio Jabuti ${ }^{9}$ que separam a categoria romance em romance literário e romance de entretenimento, como se o segundo não possuísse características estéticas (ou literárias) que o liguem ao primeiro.

Contudo, a história dessa literatura do insólito (aquela que não é habitual, corriqueira) demonstra-se como uma literatura de confronto, de reescritura e mesmo de reposição da realidade, já que, por vezes, foi por meio dela, ao recriar o mundo ao seu redor, que o homem conseguiu manter-se forte em momentos conflituosos. Afinal, a literatura possibilitou ao homem confrontar as mazelas quotidianas, principalmente ao se aventurar pelo maravilhoso (NODIER, 1970, p.

8 Em um mundo que é o nosso, aquele que conhecemos, ocorre um evento que não pode ser explicado pelas leis deste mesmo mundo familiar. Aquele que percebe o evento deve optar por uma das duas soluções possíveis: ou bem é uma ilusão dos sentidos, um produto da imaginação e as leis do mundo permanecem o que são; ou bem o evento realmente ocorreu, e é parte integrante da realidade, porém, então, essa realidade é regida por leis desconhecidas por nós. (TODOROV, 1970, p. 29, tradução livre)

9 https://www.premiojabuti.com.br/eixos-categorias/ 
123). Assim, como diz Louis Vax "el personaje fantástico es el hombre que se ha alejado de la humanidad, para unirse con la bestia"10 (VAX, 1965, p. 14).

Ainda, de acordo com Remo Ceserani, o "conto fantástico envolve fortemente o leitor, leva-o para dentro de um mundo a ele familiar, aceitável, pacífico, para depois fazer disparar os mecanismos da surpresa, da desorientação, do medo" (CESERANI, 2006, p. 71). Nesse mundo, passível de reconstruir mundos, o homem capaz de unir-se a besta pode, ainda, considerar-se herói. E, é justamente devido a essa potencialidade de envolvimento do leitor que o fantástico chama tanto a atenção dos jovens em detrimento a outros gêneros literários. $A$ exemplo dos contos de Noite na taverna, de Álvares de Azevedo, que conforme relatam Silvio Romero (1888) e José Veríssimo (1901) eram devorados pelos jovens estudantes do Colégio Pedro II. Quase dois séculos depois, essa predileção ainda se verifica (SANFELICI; SILVA, 2015).

Com base nessas configurações, vê-se que o mundo fantástico, composto a partir da categoria do insólito, conteria uma carga de indefinição presente desde a definição do termo insólito. O termo "carrega consigo e desperta no leitor [...] o sentimento do inverossímil, incômodo, infame, incongruente, impossível, infinito, incorrigível, incrível, inaudito, inusitado, informal..." (COVIZZI, 1978, p. 26), permitindo-se olhar para si e para o seu mundo com olhar renovado.

Cumpre ressaltar que, os novos processos de valorização das literaturas de cunho insólito/ fantástico, principalmente nas últimas décadas do século $X X$, demonstraram o interesse crescente de estudiosos, pesquisadores, leitores etc. pelas literaturas fantásticas, colocando-as em um papel bastante distinto de outrora. Hoje tal literatura vem construindo-se como parte importante da literatura contemporânea, a exemplo da fama alcançada pela coleção Harry Potter, de J. K. Rowling e, também, da dos clássicos de J. R. R Tolkien que parecem ter sido (re) descobertos pela juventude contemporânea, em especial a brasileira. Trata-se de títulos que foram adaptados para o cinema e conquistaram espaços nas casas de cada telespectador, tornando-os coadjuvantes de personagens viventes em

10 "o personagem fantástico é o homem que se afastou da humanidade para se unir à besta" (VAX, 1965, p. 14, tradução livre) 
mundos a serem conquistados, apreciados e também salvos. Um movimento que condiciona o expectador, após ver o filme, voltar-se para o livro.

Como se pode perceber o cinema fortaleceu alguns vínculos, contornando em certo sentido o distanciamento existente entre leitor e leitura que se verifica especialmente na realidade brasileira. Ainda, conforme Furtado, "o fantástico abre em paralelo um debate que, travando-se afinal entre a razão e o seu oposto, toma muitas vezes forma representando o antagonismo entre as potencialidades da espécie humana e as limitações que lhe são inerentes" (FURTADO, 1980, p. 134). O paralelo entre poderes e limitações permitiu a toda uma geração, a geração de Harry Potter, voltar à busca de informações a partir do conhecimento literário, oportunamente oferecido por meio dos contos de Murilo Rubião em peças teatrais, caso, por exemplo, do espetáculo "O Pirotécnico Zacarias”, montagem realizada pelo grupo teatral Giramundo (GIRAMUNDO, 2019). Para Falcão, "a partir do momento em que obras literárias como O Senhor dos Anéis e Harry Potter ganharam as telas do cinema, multidões ficaram ávidas por conhecer mais e mais esses universos" (FALCÃO, 2014, s.n.).

É nesse contexto, e em certo sentido a partir dos dispositivos modernos, que se torna essencial focalizar o modo como a leitura de obras pertencentes ao fantástico são particularmente atraentes ao público, especialmente ao juvenil, sem risco de errar, mais afeito aos voos de vassoura (Rowling) e enfrentamento de forças sobrenaturais (Tolkien). Nessa sequência, os pedidos mais desenfreados e completamente alucinados, como o que se pode destacar em "Bárbara", de Murilo Rubião (2005), captam a atenção de leitores ávidos pelo fantástico. Para Rios:

O mais fantástico da literatura fantástica, porém, é que ela se mantém mais forte do que nunca com o passar dos anos, dando origem a inúmeros filmes, peças de teatro e seriados apesar de ser considerada pela crítica especializada um gênero menor... Quanto a nós, leitores, continuamos abdicando de nossos Mundos Primários e mergulhando com maior prazer possível nesses Mundos Secundários em que, talvez, encontremos apenas a fantasia, mas a nós mesmos. (RIOS apud BRAGA e BEZERRA, 2014, s.n.) 
Partindo-se, pois, do fantástico, e percebendo a forma de concretização da literatura na configuração do contexto de ensino e aprendizagem percebe-se ser:

simplesmente "fantástico" observar a relação leitor/autor, porque um transforma, através de jogos de palavras, o mundo ao seu modo de ver; o outro viaja neste mundo e tira também, ali, suas próprias conclusões. Há uma relação entre o imaginário e o real, talvez, o desejo de explicar certos fenômenos existenciais. "A representação do sobrenatural na literatura se configura na busca de explicação e sentido para a existência, reflexo dos conflitos íntimos e anseios do homem da época" (LEÃO, 2011, p. 44). (RIOS apud BRAGA e BEZERRA, 2014, s.n.)

Destaca-se, por conseguinte, a necessidade da leitura no desenvolvimento do aprendizado e, para tanto, ressalta-se a importância do professor no incentivo a essa, guiando o aluno à formação de um hábito, tornando-o propriamente um leitor. Trata-se, desse modo, de um caminho de condução e de exemplo, cabendo ao professor-leitor construir o aluno-leitor. Nessa via de mão dupla, constroem-se sujeitos mais críticos e conscientes de sua capacidade de interpretar os mundos que os cercam. Em um tempo de muita informação e poucas formas de lidar com tanto saber disperso e nem sempre assertivo, é essencial o incentivo ao crescimento de cada educando, formando indivíduos capazes de ler uma notícia e interpretá-la, sem manipulação. Assim, "eventos que promovam o debate e a criatividade das pessoas, seja em relação a obras literárias, cinematográficas, teatrais ou plásticas, são fundamentais para o crescimento dos sujeitos" (FALCÃO, 2014, s.n.). O espírito crítico do educando deve ser desenvolvido em ações de leitura e, logicamente, produção de conteúdo. De acordo com Cristiane Moreira da Costa:

[...] acreditamos ser esse o lugar onde a literatura precisa estar sempre presente, cabendo ao professor a ação de oferecer aos alunos livros que Ihe permitam o contato com a estética literária, despertando-os para uma experiência de fantasia, descobertas e transformações que podem ser provocadas com essa leitura, uma vez que, diante do texto, "[o] leitor vai ao deserto, fica diante de si mesmo; as palavras podem jogá-lo para fora de si mesmo, desalojá-lo de suas certezas, de seus 'pertencimentos'" (PETIT, 2008, p. 147, grifo da autora). (COSTA, 2019, p.74)

Mas para atingir-se tal objetivo é necessário desenvolver no estudante o gosto pelo ato de ler. Como isso pode ser realizado? Por meio da solicitação de pesquisas, análise de conteúdos e, principalmente discussão. Mas é necessário 
estabelecer um diálogo com algo que the apetece para, paulatinamente, dá-lhe outras doses de leitura. Assim, o jogo com palavras e, ainda, o modelo de construção de informação, com base no saber do aluno, pode ser realizado por meio de atividades lúdicas de percepção de algo em um texto cinematográfico como os acima mencionados e, posteriormente, a apresentação de contos, como os do escritor Murilo Rubião. O autor em questão tem em seu conjunto de contos conteúdos diversos e a materialização de percepções do quotidiano que se dão pelas vias do fantástico.

\section{RUBIÃo E A LITERATURA QUE SE LÊ NA ESCOLA}

As situações abordadas nos contos de Murilo Rubião podem, por sua vez, fornecer uma dinâmica interdisciplinar no âmbito escolar, instituindo uma formação geográfica, histórica e, óbvio, literária. Trata-se, afinal, de um escritor mineiro, que se aproxima, em seus escritos, da ironia de Machado de Assis, que dentro de sua vasta obra também escrevera alguns textos de natureza fantástica. A escrita de Rubião, tão peculiar quanto a de seu antecessor, demonstra-se permeada por situações corriqueiras, porém profundamente desafiadoras, como as passíveis de serem vislumbradas em "O Edifício" (2005). Não se vê todos os dias, por fim, a construção de um arranha-céu interminável e não se sabe bem a que custo. Ou se vê? Cabe ao leitor-professor questionar e, na sequência, guiar seu aluno ao caminho da leitura.

De acordo com Rildo Cosson (2010; 2018) e Patrícia Corsino \& Claudia Pimentel (2014), o texto literário jamais deve ser usado como mero pretexto para o estudo de ortografia, gramática e história literária. É imperativo, portanto, que no processo de mediação de leitura sejam considerados os elementos textuais e contextuais da obra com o fim específico de despertar no aluno interesse pelo texto trabalhado em sala de aula. Despertar de maneira tal que conduza o aluno a buscar aquele mesmo autor, aquele mesmo gênero ou afins nas bibliotecas e nas livrarias. Sendo assim, o professor não lecionaria visando exames como o ENEM e vestibulares, mas, sobretudo, visando a formação de um leitor literário. 
Conforme explicitado por Braga e Bezerra (2014), a relação que se trava entre o universo do imaginário e da realidade factual engendra o "desejo", senão, a necessidade de explicar o inexplicável. Com isso, o texto fantástico permitiria ao aluno discutir questões assaz problemáticas de nossa sociedade com maior fluidez do que quando frente a um texto real-naturalista, por exemplo.

Assim, no caso do texto de cunho fantástico, a dúvida, o medo, a angústia ou mesmo a alegria das fadas podem ser os caminhos para descobrirem-se, além de arranha-céus infinitos ou pessoas mágicas, meios de capacitar o aluno a refletir acerca da vida em sociedade. Caso, por exemplo, do conto "O Ex-Mágico da Taberna Minhota", sujeito mágico e capaz de magias infindáveis. Contudo, também um sujeito corroído por amarguras infindáveis. Há aqui mais um instrumento pertencente ao fantástico para pensar-se as duas faces desse sujeito incomum encontrado na literatura. Como são as pessoas atualmente? Quem são os seres capazes de magias ou de se reinventar? Eis os instrumentais que podem ser usados para um amplo espectro de trabalho no âmbito escolar.

As narrativas de Rubião percorrem o imaginário e mesmo o mundo dos sonhos ou das alucinações, principalmente ao tratarem com um aspecto muito próprio de temas tão característicos e comuns ao ser humano. Foram escolhidos três (3) contos, não ao acaso, mas tendo como fim refletir e compreender os instrumentais da literatura fantástica e como pode-se lançar mão desta literatura para fundar no aluno o profundo desejo pelo aprendizado e, ainda, pelo desenvolvimento de sua capacidade de refletir.

"Bárbara", por exemplo, é uma narrativa marcada pelo desejo. Trata-se de um texto que pode atingir público diverso, contemplando diferentes graus de preenchimento e compreensão. $O$ enredo centra-se na configuração de uma esposa sempre muito caprichosa e cheia de pedidos e feitos a serem realizados. A história é contada por um marido sedento por afeto, determinado a concretizar cada mínimo desejo de sua esposa, que a cada novo pedido engorda. Natural? Sobrenatural? Sólito? Insólito? Não se pode aqui revelar os inimagináveis pedidos que movem Bárbara, contudo, deve-se ressaltar a importância da recorrente 
concretização para forjar o pedido seguinte. Vê-se, desse modo, que o cerne do conto é o casamento e, se se pode afirmar prematuramente, o amor. Há, portanto, maneiras diversas de concretizar-se a leitura do conto, desde uma perspectiva a partir da construção do amor, como uma noção voltada para a continuidade do desejo ser em parte motivada por qualquer insatisfação romântica. Será que as respostas estão no conto? Quais são as configurações presentes nessa personagem? E como questioná-las? Eis a dúvida, que se bem fundamentada pode garantir fortuitas conquistas em sala de aula, principalmente em debates acerca das ficções do insólito.

Algumas perguntas parecem complicadas ou mesmo muito voltadas para o campo dos Estudos Narrativos ou Estudos Literários, entretanto, a motivação dos questionamentos é permitir que façamos uma reflexão acerca do mundo que nos cerca e de que modo o escritor apreende e constrói seus universos ficcionais. Nesse sentido, aponta-se para as reflexões derivadas de "O Edifício", outro conto do autor que brinca com situações comezinhas para estruturar-se. A história revela-se pouco a pouco confusa e bastante intrigante, ainda que tenha início na construção de um arranha-céu. Na engenharia construir um prédio não seria um ato não-natural, ao contrário, hoje, projetar um prédio de muitos andares é bastante comum. A complexidade da construção está inesperadamente na demanda por uma estruturação talvez não concretizável. Anos infindáveis foram acumulados na fundação do edifício. Será que se trata de um conto fantástico? Coloca-se, então, a questão para que se possa a partir dessas primeiras reflexões pensar acerca da angústia da personagem principal diante de todos os acontecimentos de sua vida após ser contratado.

Não são poucos os caminhos a serem alcançáveis em "O Edifício", já que um engenheiro recém-contratado precisa administrar uma obra estratosférica e garantir sua concretização, ainda que ela já tenha perdurado por anos. Qual a pessoa que nunca realizou uma obra em casa? Quantos são os problemas simples da realização de uma obra? A construção do fantástico permite ao leitor vivenciar a angústia da dúvida? Explorar a circunstância base pode em muitos 
casos quebrar complicações e instituir um ambiente de reflexão e crescimento, professores e alunos podem em um crescente extrapolar espaços e dividir a concretização dos saberes derivados da interpretação e do saber. Crescer remete, assim, ao conto "O ex-mágico da taberna minhota". Nele, não há crescimento, não há adaptação, não há infância e, então, o ex-mágico constrói-se por meio da capacidade da mágica. No entanto, mágicas e mesmo o quotidiano de qualquer pessoa têm custo. O preço pago pelo ex-mágico é não ter passado. Qual o preço que cada pessoa carrega? Qual o dom natural de cada pessoa? Pode-se, portanto, desencadear a partir da narrativa um conjunto de reflexões pessoais e, ainda, coletivas, reforçando a ideia de metamorfose, de transformação, pela qual cada ser humano passa. É óbvio que as mudanças por que passa o ex-mágico denotam uma atmosfera feérica e, por isso, ilimitada, visto que não há ser humano capaz de fazer objetos escorregarem se suas mãos. Sendo assim a estranheza, a alegoria, o inusitado torna-se atraentes ao leitor.

A narrativa faz com que cada leitor vivencie o percurso realizado pelo ex-mágico em sua vida. Algumas questões de insatisfação da personagem caracterizam-se mesmo como excelentes suportes para atividades em classe. Afinal, cada pessoa pode imaginar como se sentiria ao ser capaz de realizar mágicas. Então, em uma simples atividade seria possível criar um debate contra e a favor de mágicas. As possibilidades de diálogo entre o quotidiano do aluno e a leitura são infindáveis, desde que cada professor esteja comprometido com sua própria vontade de compartilhar sua paixão pela leitura.

As três narrativas de Murilo Rubião admitem, em certo sentido, um percurso, ainda que breve, pelo inventário de mundos e circunstâncias elaboradas pela imaginação do autor, permitindo que se possa transbordar os limites da leitura que valora apenas o ensino gramatical e descontextualizado, através das imagens produzidas que assomam as palavras postas no papel. Passa-se, por conseguinte, a uma intervenção propositalmente ligada ao desenvolvimento de inúmeras capacidades do aluno. Posto que a compreensão da linguagem alegórica da qual reclama o fantástico de Rubião requererá muito mais do aluno. Para 
tanto, pretende-se como desfecho do percurso elaborado a proposta de uma atividade didática possível e que ajude o professor a cativar o aluno por meio da curiosidade e da surpresa.

\section{PROPOSTA DE ATIVIDADE DE AULA}

Abaixo disponibilizamos um plano complementar de atividade de leitura dos três contos de Murilo Rubião brevemente comentados neste artigo, a saber: "Bárbara"; "O Edifício"; "O ex-mágico da taberna minhota”. A presente proposta pode realizar-se em sala de aula, grupo de leitura ou em atividade interdisciplinar. $O$ público alvo são turmas de segunda e/ou terceira série do ensino médio regular. $1^{\circ}$ passo - conquistar a confiança dos alunos ao fornecer um repositório de saber acerca do mundo fantástico tão presente nos cinemas. Para tal, mencionar o conteúdo de obras próximas ao imaginário dos alunos - Harry Potter, Saga Crepúsculo; Senhor dos Anéis -, e tantas outras narrativas literárias e cinematográficas que abordam temáticas afins ao fantástico atualmente;

$2^{\circ}$ passo - organizar a turma em grupos de 4 a 6 alunos;

$3^{\circ}$ passo - incentivar os alunos a proporem exposições sobre a temática;

$4^{\circ}$ passo - propor a leitura compartilhada de um dos contos em sala (preferencialmente com os alunos sentados em roda) e, posteriormente, incentivá-los a terminar a leitura dos outros dois contos.

$5^{\circ}$ passo - sugerir uma pesquisa acerca dos pontos elencados em sala de aula, a partir de termos centrais (centrais, porém não únicos):

Desejo (indicar o desejo em sua relação com almejar algo)

Trabalho

Profissão

Mágica

Metamorfose

Construção 
Os vocábulos acima sugerem elementos muito amplos, entretanto, a proposta visa conectarmos a orientação da pesquisa ao conteúdo discutido em sala. O que há de conexão entre a língua e a constituição da literatura que ora trabaIhamos? Como esses pontos aparecem em nosso quotidiano?

$6^{\circ}$ passo - solicitar aos alunos um trabalho escrito. Nem longo, nem fruto de suas pesquisas, mas fruto de suas reflexões. O tema da redação proposta poderia ser: E se ...

$7^{\circ}$ passo - solicitar aos que desejarem a apresentação de suas reflexões escritas.

\section{CONSIDERAÇÕES FINAIS}

O caminho do incentivo à leitura ainda é longo e deveras tortuoso. A formação do leitor literário implica um trabalho que vai além da simples transmissão de conteúdos. Contudo, cabe ao professor leitor incentivar ao máximo o aluno de forma a transmutá-lo também num leitor. Para isso, é preciso sobretudo ler literatura. Ademais, é imperativo que durante o processo de mediação de leitura e ensino de literatura, sejam forjadas conexões no que tange ao saber e à difusão da leitura como modelo de desenvolvimento de capacidades múltiplas.

Como pôde ser observado, através dos contos de Murilo Rubião ora comentados, textos que abordam o insólito ficcional, isto é, fantásticos, possuem a potencialidade de exploração de diversas temáticas que ultrapassam a língua e o texto literário, permitindo ao leitor, neste caso ao aluno, refletir sobre o mundo que o cerceia. Sendo assim, além de propiciar o trabalho de literatura que coloque o texto literário em sua centralidade, admite também ações transdisciplinares dado às reflexões que engendra. Isso porque, rememorando Antonio Candido, "a literatura confirma e nega, propõe e denuncia, apoia e combate, fornecendo possibilidades de vivermos dialeticamente os problemas" (CANDIDO, 2011, p.177). $\mathrm{E}$, no caso do fantástico, as possibilidades tornam-se infinitas. 


\section{REFERÊNCIAS}

BRAGA, Marília da Costa Silva e BEZERRA, Adriano Alves. A literatura fantástica como incentivo à leitura. In: Anais Enlije. Campina Grande: Editora Realize. Disponível em <https://www.editorarealize.com.br/editora/anais/enlije/2014/ Modalidade_1datahora_25_05_2014_19_40_09_idinscrito_745_be3f4be712591bb9aaf5d315d23844a9.pdf>, acessado em 27 ago. 2020.

BUZEN, Clécio. A fabricação da disciplina escolar Português. In: Revista Diálogo Educacional. Curitiba, vol. 11, n. 34, 2011.

CANDIDO, Antonio. O direito à literatura. In: Vários Escritos. Rio de Janeiro: Ouro sobre o Azul, 2017.

CESERANI, Remo. O Fantástico. Curitiba: EdUFPR, 2006.

CORSINO, Patrícia; PIMENTEL, Claudia. Reflexões sobre a leitura literária na escola. In: CORSINO, Patrícia (org). Travessia da Literatura na Escola. Rio de Janeiro: 7Letras, 2014.

COSTA, Cristiane Moreira da. 0 universo fantástico - uma experimentação para o letramento literário. Dissertação. (Mestrado Profissional em Letras). Instituto de Lestra e Linguística., Faculdade Federal de Uberlândia. Uberlândia, 2019. Disponível em: https://repositorio.ufu.br/bitstream/123456789/25346/1/UniversoFantasticoExperimenta\%c3\%a7ao.pdf Acesso em 11 jul. 2021.

COSSON, Rildo. Letramento literário: teoria e prática. $2^{a}$ edição. São Paulo: Contexto, 2018.

COSSON, Rildo. O espaço da literatura na sala de aula. In: Literatura: ensino fundamental. Brasília: Ministério da Educação, Secretaria de Educação Básica, 2010.

COVIZZI, L. M. O insólito em Guimarães Rosa e Borges. São Paulo: Ática, 1978.

FALCÃO, Duda. Literatura fantástica e o incentivo à leitura. In: Extra Classe. Coluna Opinião. 12 set. 2014. Disponível em https://www.extraclasse.org.br/ opiniao/2014/09/literatura-fantastica-e-o-incentivo-a-leitura/ acesso em 27 ago. 2020. 
FURTADO, F. A construção do fantástico na narrativa. Lisboa: Livros Horizonte, 1980.

FURTADO, Filipe. "Fantástico (gênero)"; "Fantástico (modo)". In: CEIA, C. (org.). E- Dicinário de termos literários. Disponível em: http://www.edtl.com.pt, acesso em: 24/07/2020. [2012]

GAMA-KHALIL, Marisa. "Fantástico - modo". In: REIS, Carlos; ROAS, David; FURTADO, Filipe; GARCÍA, Flavio; FRANÇA, Júlio (Editores). Dicionário Digital do Insólito Ficcional (e-DDIF). Rio de Janeiro: Dialogarts. Disponível em http:// www.insolitoficcional.uerj.br/m/medo/ Acesso em 30 nov. 2020. [2019]

GIRAMUNDO. Espetáculo "O Pirotécnico Zacarias". Adaptada para teatro e dirigida por Marcos Malafaia, com patrocínio do CCBB (Centro Cultural Banco do Brasil). 22 ago. 2019 a 16 set. 2019. Disponível em http://giramundo.org/espetaculo/o-pirotecnico-zacarias/ Acesso em 27 out. 2020.

MICHELLI, Regina. Contos fantásticos e maravilhosos. In: GREGORIN FILHO, José Nicolau (org.). Literatura infantil em gêneros. São Paulo: Ed. Mundo Mirim, 2012. cap. 2. p. 26-56.

NODIER, Charles. Du fantastique en littérature. In: JUIN, H. Charles Nodier. Paris: Seghers, 1970.

PETIT, Michèle. Os jovens e a leitura: uma nova perspectiva. São Paulo: Editora 34, 2013.

ROMERO, Silvio. História da Literatura brasileira. Tomo II. Rio de Janeiro: Garnier, 1888.

RUBIÃO, Murilo. Murilo Rubião: contos reunidos. São Paulo: Ática, 2005.

SANFELICI, Aline de Mello; SILVA, Fábio Luz da. Os adolescentes e a leitura literária por opção. In: Educ. rev. (57) Set 2015. Disponível em: https://doi. org/10.1590/0104-4060.38946 acesso em 07 jun. 2021

SCHWARTZ, Jorge. Murilo Rubião: A poética do Uroboro. São Paulo: Editora Ática, 1981.

SOARES, Magda. Português na escola: história de uma disciplina curricular. In: BAGNO, Marcos (org.). Linguística da Norma. São Paulo: Loyola, 2004. 
TODOROV, Tzvetan. Introduction à la littérature fantastique. Paris: Éditions du Seuil, 1970.

VAX, Louis. Arte y Literatura fantásticas. Buenos Aires: EUDEBA, 1965.

VERÍSSIMO, José. Estudos de literatura brasileira. Belo Horizonte, Itatiaia, 1977.

VIEGAS, Ana Cristina Coutinho. Alguns desafios do ensino de literatura na educação básica. In: Gragoatá, Niterói, n. 37, 2. Sem. 2014.

WERNECK, Humberto. O mágico da palavra. In: Suplemento Literário de Minas Gerais. Belo Horizonte, v.22, n.1060, p.12, fev. 1987. 
doi $10.48209 / 978-65-89949-16-7$

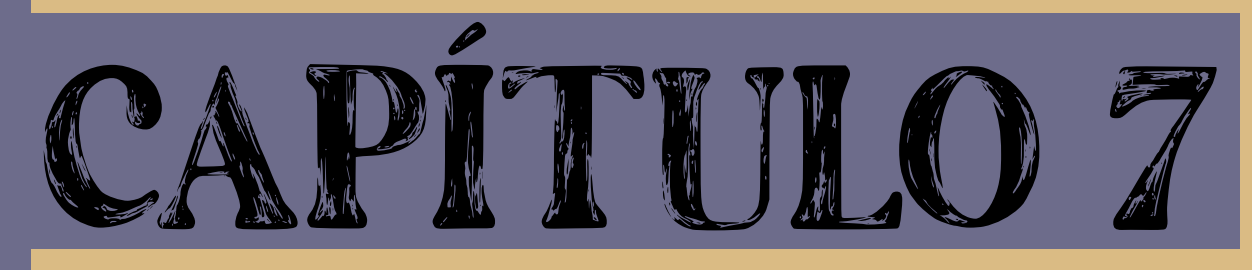

\section{ERA UMA VEZ: UM PROJETO QUE FORMA LEITORES E MEDIADORES DE LEITURA}

Arthur Scapini Analoren Fernandes 


\section{INTRODUÇÃO}

Os textos literários provocam reflexões de natureza cognitiva e afetiva, permitindo ao leitor a entrada em um mundo desconhecido, porém, instigante, que desenvolve o imaginário, despertando a curiosidade, a criatividade e o senso crítico. Considerando a leitura como uma forma de se perceber o mundo e a realidade que o cerca, a literatura possibilita a formação de cidadãos capazes de entender a realidade social, atuar sobre ela e transformá-la.

Sabe-se, ainda, que as crianças têm um enorme potencial de criatividade que precisa ser despertado e promovido. Todavia, nem sempre essas crianças encontram na sala de aula atividades que motivaram seu interesse pela leitura e pela criação de histórias, visto que, muitas vezes, o texto literário é utilizado como um pretexto para o trabalho da gramática por parte dos professores; principalmente nos anos iniciais, fase em que o estudante está ávido por experiências que o motivem enquanto leitor.

A partir desse enfoque é que o projeto de extensão "Oficina de contação: a formação de leitores" foi idealizado. O projeto é coordenado pelos professores Mairim Linck Piva, Adriana de Oliveira Gibbon e Artur Emílio Alarcon Vaz, da Universidade Federal do Rio Grande - FURG, e integra o programa de extensão "Socializando a leitura", dos mesmos coordenadores.

O foco principal do projeto é despertar o interesse pela leitura e criação de histórias por parte do público-alvo, trabalhando a criatividade de crianças e adolescentes, desenvolvendo a expressão oral e escrita dos alunos e aguçando, de maneira lúdica, o hábito da leitura. Ademais, o projeto objetiva formar mediadores de leitura, já que o foco é a contação de histórias por parte dos acadêmicos integrantes do projeto.

Dessa maneira, o projeto proporciona a seus integrantes uma experiência enriquecedora, pois os aproxima dos alunos da educação regular já que, ao desenvolver atividades nas escolas, os graduandos entram em contato com histórias, experiências, medos e sonhos. 
As ações do projeto "Oficina de contação: a formação de leitores" foram iniciadas no ano de 2013, quando era composto apenas pela graduanda de Letras Ana Luísa Cosme e pela professora Mairim Piva. A universidade não possuía nenhum projeto em atividade que possibilitasse aos alunos de graduação a contação de histórias em escolas da cidade. Assim, fundou-se o projeto com o intuito de proporcionar o incentivo da leitura bem como o contato com a realidade escolar por parte da acadêmica.

Em seu primeiro ano de funcionamento, as ações aconteceram na Escola Estadual de Ensino Médio Dr. Augusto Duprat. As atividades aconteciam semanalmente e contavam com a participação de vinte crianças do primeiro ao quinto ano do Ensino Fundamental. Essas crianças participam do projeto Mais Educação do Governo Federal. A escola contava com uma oficina de futebol e autorizou que as atividades do projeto de contação ocorressem no mesmo dia da referida oficina, dividindo o tempo com ela. Dessa maneira, semanalmente eram realizadas atividades de contação de histórias e mediação de leitura, criação de narrativas por parte dos estudantes, empréstimos de livros etc.

Em 2014, a acadêmica iniciou o mestrado em Letras e realizou apresentações em eventos acadêmicos e participações em cursos de extensão na universidade. A partir de uma apresentação do projeto em um evento de acolhida do Curso de Letras, no início do ano de 2015, surgiu a ideia de agregar mais voluntários e retomar as ações do projeto de contação, levando-o para outras escolas, inclusive onde a mestranda atuava.

Assim, o projeto vinculou-se à Escola Municipal de Ensino Fundamental em Tempo Integral Prof. Valdir Castro e teve a adesão de mais seis voluntários. Neste mesmo ano, além das ações desenvolvidas nessa escola, o projeto também fez intervenções em atividades literárias que aconteceram em diversas escolas da cidade de Rio Grande. Essas intervenções consistiam em contações de histórias através de diversos recursos além de saraus literários. Os integrantes do projeto seguiram divulgando nos eventos de que participaram, expondo como ocorriam 
as atividades fora da universidade, além de participarem de cursos de extensão acerca da formação do leitor e do incentivo à leitura.

No ano de 2016, o número de voluntários cresceu, chegando a onze integrantes. Dessa forma, foi possível integrar-se a mais uma escola da cidade, a Escola Municipal de Ensino Fundamental Cidade do Rio Grande - CAIC. As intervenções seguiam os mesmos moldes: contações e criações de histórias coletivas. Na EMEF em T.I. Prof. Valdir Castro, as ações eram semanais e no CAIC em datas esporádicas, como Semana da Criança, Dia do Livro, Feira Literária etc.

No ano de 2017, o projeto cresceu ainda mais, totalizando 20 integrantes. Além das duas escolas parceiras, que contavam com ações fixas de contação de histórias, os voluntários passaram a realizar atividades, aos sábados, na ala pediátrica do Hospital Universitário. Além disso, o projeto também realizou ações em atividades literárias de outras escolas da cidade, além da participação em eventos maiores como a Feira do Livro da FURG, a Festa de Literatura de Rio Grande (FLIRG) e Ondas de Leitura, evento desenvolvido pela Secretaria de Municipal de Cultura. Nesse mesmo ano, o projeto foi procurado pela Secretaria de Educação do Município para realizar um curso de extensão acerca da mediação de leitura com professores da Educação Infantil do Município, o qual aconteceu em duas edições e contou com a participação de mais de 90 professores da rede municipal.

Em 2018, outros voluntários passaram a fazer parte do projeto, enquanto alguns deixaram o mesmo por terem concluído sua graduação e terem seguido outros rumos acadêmicos, inclusive pós-graduações. As atividades na Escola Valdir Castro tiveram continuidade, porém, através de oficinas semanais em que eram realizadas atividades de contação e criação de histórias com alunos dos Anos Iniciais. Atualmente, as atividades na escola seguem os mesmos moldes.

Ainda em 2018, o projeto participou da Feira do Livro da FURG através de uma tenda localizada na Rua das Crianças, intitulada "Tenda do Terror", onde foram realizadas contações de histórias com essa temática ao longo da Feira. Nesse ano, a parceria com a rede municipal teve continuidade, oferecendo nova- 
mente o curso de mediação de leitura para os professores. Esse curso foi ministrado pelos voluntários do projeto com a orientação dos coordenadores.

Em 2019 as atividades tiveram continuidade e o projeto, mais uma vez, cresceu, passando a realizar ações no Asilo da cidade. As atividades nas escolas permaneceram, assim como a participação em Feiras Literárias, eventos na cidade, participação em eventos acadêmicos, saraus literários etc.

\section{DESENVOLVIMENTO}

O projeto é composto por ações contínuas visando ao estímulo à leitura e à produção textual de estudantes da Educação Básica. Ele acontece em parceria com escolas da rede pública e atua também em eventos escolares, como feira de livros, oficinas de literatura e outros, a partir de convites. As atividades do projeto consistem em contar histórias e estimular as práticas de produções textuais e do gênero textual desenho, sendo essa um texto não verbal. Todas essas ações são executadas por graduandos e pós-graduandos da Universidade Federal do Rio Grande. As práticas das cotações iniciam-se através da escolha das histórias que serão contadas pelos acadêmicos, considerando sempre a faixa etária do público que irá participar como ouvinte das atividades. As histórias são narradas ou dramatizadas pelos bolsistas que participam do projeto, após a contação, os graduandos iniciam uma mediação entre os estudantes, em que eles interagem, apresentando suas interpretações sobre a história contada, contam suas próprias histórias, desenvolvem sua criatividade e sua imaginação, expondo assim suas emoções e seus medos, confrontando-os sempre de uma maneira lúdica. Para o teórico Richard Bamberger (2008, p.23),

O ensino da leitura deveria corresponder à percepção que conseguimos da natureza da leitura. Processo complexo, a leitura compreende várias fases de desenvolvimento. Antes de mais nada, é um processo perceptivo durante o qual se reconhecem símbolos. Em seguida, ocorre a transferência para conceitos intelectuais. Essa tarefa mental se amplia num processo reflexivo à proporção que as ideias se ligam em unidades de pensamento cada vez maiores. O processo mental, no entanto, não consiste apenas na compreensão das ideias percebidas, mas também na sua interpretação e avaliação. 
As práticas em questão relatadas iniciaram-se através de leituras, narrativas e/ou dramatizações de obras clássicas e contemporâneas por parte de dois integrantes que atuam no projeto. Reunidas algumas histórias que foram dramatizadas por eles, os mesmos atuaram como personagens, caracterizando-se com máscaras. Em outras ocasiões, os acadêmicos deram enfoque ao livro com o objetivo de familiarizar os alunos ao objeto, para que assim se sentissem incentivados e despertassem o hábito pela leitura.

\section{RESULTADOS E DISCUSSÃo}

Relato de experiência 1:

Em 2019, por indicação de amigos que estavam comigo no Diretório Acadêmico de Letras, interessei-me pelo projeto "Oficina de Contação: a formação de leitores", no qual entrei como voluntário.

A possibilidade de estar inserido nas escolas e ter a oportunidade de trabalhar com o imaginário das crianças despertou minha motivação para o futuro docente. Com uma certa semelhança com os filósofos da Grécia Antiga que contavam suas teorias e histórias para os demais curiosos em praças públicas, os contadores de histórias trabalham as formas de cativar as crianças para proporcionar emoções distintas, como felicidade, curiosidade, aprendizagem e, acima de tudo, para desmistificar a ideia de que livros são inalcançáveis. O incentivo à prática da leitura, como uma introdução na experiência docente, estabelece uma relação ainda mais sólida como futuros professores, porque há não apenas uma construção de leitores, mas também de cidadãos. Para Paulo Freire (1992, p.11):

\footnotetext{
A leitura do mundo precede a leitura da palavra, daí que a posterior leitura desta não possa prescindir da continuidade da leitura daquele. Linguagem e realidade se prendem dinamicamente. A compreensão do texto a ser alcançada por sua leitura crítica implica a percepção das relações entre o texto e o contexto.
}

O ambiente de ensino torna-se ainda mais amplo, pois introduz ao aluno a experiência de estabelecer uma relação de leitura e entendimento de palavras com as suas interpretações de mundo. 
Minha primeira experiência no projeto foi na Escola Estadual Revocata Heloisa de Mello, com contos de terror e as crianças estavam ansiosas, apreensivas e com muitas indagações. A história que contei baseava-se em um pequeno susto no final, em que as crianças participavam com muitas risadas ao descobrirem o final do enredo. Quando terminava a história, sempre se ouvia um "eu nem tive medo", o que geralmente era falado pelas crianças mais apreensivas com unhas roídas. Tudo isso era motivo de muita descontração e felicidade, todos que estavam presentes se divertiam, inclusive as professoras que levavam suas turmas para participar do projeto.

Minha segunda experiência, na Escola Municipal de Educação Infantil Vovó Zoquinha, foi um pouco mais agitada, pois as crianças estavam mais animadas e, dessa forma, foi mais difícil conseguir prender a sua atenção. A solução foi despertar a memória afetiva de todos perguntando quem conhecia a história da Chapeuzinho Vermelho, em que todos responderam em alto e bom tom "SIM" e, para surpresa de todos, declararei então que isso era bom, porque não seria essa a história que estava para ser contada. Partindo disso, consegui prender a atenção dos pequenos curiosos para aquela história que eles não conheciam, que seria a história da lebre e a tartaruga que pilotava um foguete.

O sucesso das atividades elaboradas deve-se ao ótimo trabalho em equipe de seus participantes, pois todas as ideias são debatidas e executadas da melhor forma possível para que todos os envolvidos tenham a melhor experiência não só como ouvintes, mas também como contadores de histórias.

Relato de experiência 2:

Como graduanda de Letras-Português da Universidade Federal do Rio Grande, conheci o projeto por meio de colegas que já participavam há algum tempo e que me relataram as experiências e as atividades que praticavam.

Foi dessa forma que me interessei e me voluntariei no início do ano de 2019. Minha primeira atividade no Contação ocorreu em abril na Escola Estadual Revocata Heloisa de Mello, em Rio Grande (RS), e a primeira história contada foi 
"O lago dos monstros", para alunos do terceiro ano do Ensino Fundamental, na faixa etária de oito a nove anos. Como era um conto de "terror", as crianças adoraram e ficaram alvoroçadas, cheias de perguntas, algumas ficaram com medo, outras contaram suas próprias histórias de terror. Foi então que percebi o quanto as atividades do Contação eram importantes para o desenvolvimento da interpretação, imaginação, criatividade e criticidade daquelas crianças.

Os docentes da escola avisaram que a segunda turma, um quinto ano com idade mais variadas, dos dez aos quinze anos - era bem desordeira, o que me causou apreensão. Fizemos uma releitura da história $A$ metamorfose, de Franz Kafka, em que relatávamos a transformação de um menino em um inseto e que, após a sua transformação, todos seus amigos e familiares o excluíram. Os alunos, descritos como agitados, silenciaram-se, todos se voltaram a nós com olhos atentos e curiosos e, quando terminamos de narrar a história, continuavam em silêncio. Perguntamos então qual a interpretação deles, o que eles acharam da história e destacamos a possibilidade de todos os fatos narrados serem uma metáfora sobre um indivíduo que foi excluído apenas por ser diferente de seus semelhantes. Indignados, os alunos responderam que: "não se abandona alguém porque ela mudou ou é diferente, a família e os amigos têm que se amar sempre". Essa foi a análise crítica deles sobre a história e ali eu vi a literatura fazendo seu papel de formar cidadãos empáticos que percebem e questionam a realidade da sociedade em que vivem e querem transformá-la.

Após efetuar essa primeira atividade, fiquei responsável por realizar outras atividades na mesma escola pública. Diante disso, eu e outros bolsistas íamos mensalmente, ao longo de 2019, a escola ler narrar e dramatizar histórias para todas as cinco turmas que lá estudavam. Sempre tivemos a preocupação de apresentar histórias com temáticas que despertassem o interesse dos alunos e apresentassem questões sociais para refletirmos juntos, claro que sempre de uma maneira lúdica, respeitando a idade dos discentes.

Em uma dessas contações, lemos o livro O mistério do coelho pensante, de Clarice Lispector, pois era um livro a que eles poderiam ter acesso, já que 
estava disponível na biblioteca da escola. Enquanto eu lia, ia apresentando as ilustrações do livro aos alunos e eles muito atentos analisavam cada detalhe, à medida que a narrativa acontecia mais curiosos eles ficavam e iam criando através do imaginário suas próprias versões da história e usavam a criatividade para solucionar o mistério do João, o coelhinho pensante que franzia o nariz e fugia da sua gaiola. Sempre resgatado pelos seus donos, o animal retornava à gaiola, mas nessas escapadas ele descobriu que a Terra era redonda, que as nuvens se mexiam e formavam coelhões no céu e que há coisas que é bom cheirar, mas não comer. João, o coelho, tornou-se um coelhinho pensante. Mas afinal por onde ia esse coelho? Esse era o maior questionamento da história e das crianças, mas todas tinham uma teoria: "Tinha um buraco na gaiola", "O Paulinho abria a gaiola escondido e o coelho fugia.", "O coelho era mágico igual aqueles que aparecem no circo"., etc. A história narrada não tinha um final, mas ela cumpriu seu objetivo e do projeto, que é incentivar o imaginário e promover o gosto pela leitura.

No mês de junho de 2019, houve a minha terceira prática do projeto. Eu e outros bolsistas fomos a mais um encontro na escola, dessa vez a atividade era voltada só para as turmas do quinto ano do Ensino Fundamental. Ao chegarmos na escola, nos dirigimos para a biblioteca e lá ficamos à espera das professoras, pois elas eram as responsáveis por levarem as turmas ao nosso encontro, ao nos ver os alunos ficaram entusiasmados, pois já sabiam do que se tratava, era hora da contação de histórias. A felicidade deles era tanta que não conseguiam parar de falar, todos queriam contar alguma história ou comentar sobre a última história que foi contada, ainda tinha os curiosos que tentavam a todo custo adivinhar qual era a próxima história que iriamos contar.

Após todo o alvoroço, começamos nossa introdução, primeiro perguntei quem gostava de contos de fadas. A maioria das meninas disseram que gostavam mais ou menos e os meninos disseram que gostavam dos Vingadores e do Slender Man (personagem de terror criado em fóruns da internet), depois perguntei quem conhecia a história da Cinderela, todos muito animados disseram - EU, aos berros. Questionei se eles sabiam o que significava a palavra releitura e, 
após escutar negativas, expliquei que era quando criávamos uma história a partir de outra já existente. Informei que iria contar uma releitura do conto de fadas $A$ cinderela e, nessa versão, a Cinderela se chamava Cindy e a estória é ambientada nos tempos atuais. No conto, a Cindy era uma jovem que morava com o pai, pois sua mãe morreu quando ela era criança. Um belo dia ou não tão assim belo, o pai da Cindy conheceu uma mulher no Tinder e resolveu casar (nessa parte da história todas crianças caíram na risada), essa mulher tinha duas filhas que eram bem malvadas e faziam bullying com a Cindy, pois morriam de inveja da inteligência, bondade e beleza da garota. Algumas meninas relataram que sofrem bullying, perguntei se era na escola e elas afirmaram que sim, então comentei que, quando isso acontecer, elas precisavam informar a professora ou algum responsável, pois fazer bullying é muito errado e não podemos fazer com os outros o que não gostaríamos que fizessem conosco. Todos eles concordaram.

Em sequência continuei narrando a história, contei que um dia o pai da Cindy ficou muito doente e morreu, então a madrasta ficou responsável pelos cuidados da protagonista, mas a viúva tratava a garota muito mal. Alguns alunos contaram que tinham madrastas, umas disseram que as madrastas eram boazinhas, outras disseram que eram meio más, mas não como na história. Mencionei que diferente da Cinderela que conhecemos, a Cindy era empoderada e não aceitava ser tratada mal, ela corria atrás dos seus sonhos.

Ao continuar a narração, relatei que a menina soube que iria ter uma festa bem legal na escola e queria um vestido bem estiloso e que, ela não tinha dinheiro, porque a madrasta não dava para ela, resolveu trabalhar, então teve a ideia de cobrar para passear com os cachorros dos seus vizinhos, pois ela amava animais e ia fazia algo de que gostava e, melhor ainda, ia ser paga por isso. Depois de duas semanas passeando com os pets diariamente, conseguiu o dinheiro para comprar o vestido. Chegando na festa, conheceu um crush chamado Prince e eles dançaram, conversaram, se divertiram, mas, em determinado momento, ela olhou o celular e viu que estava na hora de voltar para a casa, saiu correndo e 
deixou o garoto ali, sem saber onde encontrar com ela, foi quando ele olhou para o chão e viu que a jovem tinha deixado cair um colar.

O menino, muito interessado pela Cindy, postou um stories no Instagram dizendo que queria encontrar a dona do colar, avisando que estaria no shopping às 15 horas, sentado na frente do Burger King esperando a garota. Ela viu o stories e foi encontrar com ele, pois era o colar preferido dela e era herança de família. Chegando lá, o rapaz disse que a amava e a pediu em namoro, então Cindy respondeu que... Nesse momento pausei a narrativa e perguntei o que eles achavam que ela tinha respondido. As respostas foram diversas: "Ela disse que amava ele e aceitou"; "Ela disse que gosta de meninas"; "Ela disse que gosta de outro menino"; "Ela disse que queria ficar sozinha e não precisa de homem"; "Ela disse que namorava a Branca de Neve", etc. Depois de tantos relatos e finais diferentes, eu fiz suspense e disse que então iria contar o final verdadeiro, todos me olharam com curiosidade, diante disso narrei o final: Cindy disse não, ela era muito nova para namorar, queria viver outras experiências e eles mal se conheciam, mas ofereceu sua amizade e ele aceitou. Viraram melhores amigos e a menina continuou trabalhando no ramo de passeios com cachorros, até que o negócio começou a dar muito certo e ela não só passeava com os cachorros dos vizinhos, mas donos de pets da cidade inteira ligavam para ela. Cindy abriu um pet shop, virou uma empresária de sucesso e foi morar bem longe da madrasta malvada e das meias-irmãs invejosas.

Após terminar a estória, comecei a mediação para incentivar a interação dos alunos com o conto, eles adoraram o fato de ser uma narrativa com várias referências do mundo atual. Outro fator importante é que a releitura diferente do conto original traz mais representativa para aquelas crianças, tanto pela linguagem, pelo espaço, quanto pela maneira que a estória acontece, eles conseguiram se ver em inúmeras situações. Como quando é relatado o bullying, a presença da madrasta, a ausência de príncipes e princesas e todos os personagens condizem com a realidade. No entanto, ainda assim, os discentes não deixaram de exerci- 
tar o imaginário, pois, ao pensar em um final para aquela estória, eles recorreram para a imaginação e criatividade.

O projeto está sendo fundamental não só na minha vida acadêmica, profissional e pessoal, mas também de tantos outros acadêmicos que integram e já integraram o projeto, pois, ao contar uma história, estamos criando um ambiente de encantamento, suspense, emoção e isso faz com que sejamos instrumentos de incentivo ao imaginário, estimulamos o gosto pela leitura nos discentes da Educação Básica e ampliamos o seu vocabulário.

A contação de histórias é atividade própria de incentivo à imaginação e o trânsito entre o fictício e o real. Ao preparar uma história para ser contada, tomamos a experiência do narrador e de cada personagem como nossa e ampliamos nossa experiência vivencial por meio da narrativa do autor. Os fatos, as cenas e os contextos são do plano do imaginário, mas os sentimentos e as emoções transcendem a ficção e se materializam na vida real. (RODRIGUES, 2005, p. 4).

Além de que ao desenvolvermos e planejarmos nossas práticas nas escolas, estamos tendo a oportunidade de criar vínculos e obter uma proximidade maior com a docência.

\section{CONCLUSÃO}

A partir do exposto nesses relatos, é possível constatar que o projeto "Oficina de Contação: a formação de leitores" vem sendo realmente produtivo, não só para os graduandos e pós-graduandos que fazem parte do projeto, obtendo uma maior proximidade e reflexão sobre a docência e o âmbito escolar, mas principalmente para os alunos da Educação Básica, pois as ações do projeto estimulam o imaginário e fomentam o gosto pela leitura. Quando lemos, narramos ou dramatizamos uma história para os estudantes, compreendemos que estamos criando uma atmosfera de aprendizagem, sendo assim, contribuindo para a aprendizagem de conteúdo, o fortalecimento do raciocínio, a socialização e a comunicação desses discentes, o que será refletido nos anos posteriores como futuros cidadãos. 
Além disso, o Oficina de Contação promove múltiplas oficinas e atividades para professores da rede pública com o intuito de desenvolver uma formação continuada a esses docentes, cumprindo assim seu papel como projeto de extensão.

\section{REFERÊNCIAS}

BAMBERGER, Richard. Como incentivar o hábito de leitura. São Paulo: Ática, 2008.

FREIRE, P. A importância do ato de ler: em três artigos que se completam. São Paulo: Cortez: Autores Associados, 1992. (Coleção Polêmicas do nosso tempo)

RODRIGUES, Edvânia Braz Teixeira. Cultura, arte e contação de histórias. Goiânia: s/l, 2005. 
doi $10.48209 / 978-65-89949-16-8$

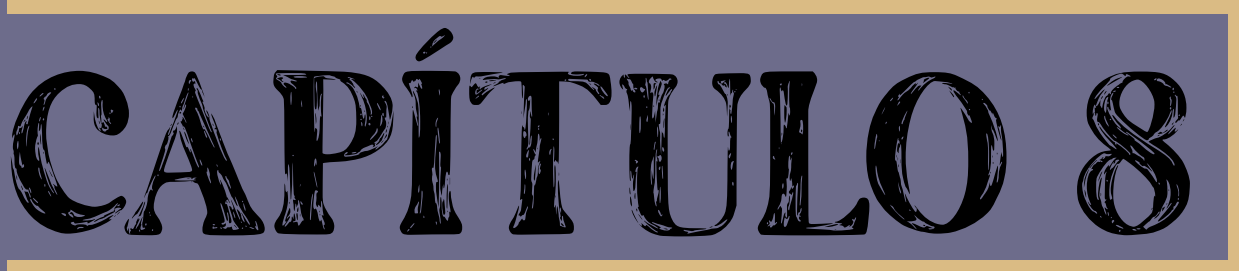

\title{
"DEFRONTE DO
} INIMIGO SARRACENO": A (DES)CONSTRUÇÃO DA IDENTIDADDE MUÇULMANA EM OS LUSÍADAS

\author{
Maurício Alves de Souza Pereira
}


"O discurso não é simplesmente aquilo que traduz as lutas ou os sistemas de dominação, mas aquilo que se luta, o poder que queremos nos apoderar". Michel Foucault

\section{INTRODUÇÃO}

Historicamente, e ainda hoje, os povos muçulmanos sofrem constantes perseguições devido às suas crenças e cultura. Essa perseguição, sobretudo à religião Islã, acontece há muito tempo, fato que se constata em vários escritos do passado, entre os quais se destaca Os Lusíadas, do escritor português Luiz Vaz de Camões.

Os Lusíadas, epopeia que canta os grandes feitos do povo português, à medida que é construída, no intuito de mostrar a grandeza de Portugal, apresenta aqueles a quem recai o domínio e as vitórias portuguesas nas batalhas, com destaque para os muçulmanos, ou mouros, como são tratados na maioria das vezes pelo poeta Camões. O poema, narrado em 10 cantos, faz reiteradas referências aos mulçumanos, ofensivas na maioria das vezes, colocando-os em uma posição inferior e atribuindo-lhes o epíteto de condenados, amaldiçoados.

Ao contar uma história, é muito comum que o poder seja apropriado por aquele que narra, sobretudo quando existe um sentimento de pertença a um determinado grupo. Um texto, qualquer que seja, mesmo que de maneira mais sutil possível, apresenta a intencionalidade de quem o escreve. No caso da obra em questão, o poeta não se preocupa em velar suas intenções, pelo contrário, a posição de destaque dada a Portugal é a mais explícita possível, bem como a inferiorização atribuída ao povo muçulmano.

Este ensaio, além de apresentar a identidade muçulmana, insultada de todos os modos na epopeia camoniana, pretende expor algumas técnicas, sobretudo discursivas, utilizadas pelo poeta para a concretização das intenções relativas à apresentação do mouro em sua obra. 
Para a realização deste trabalho bibliográfico, utilizamos como objeto de pesquisa a obra Os Lusíadas, de Camões, fazendo um recorte de algumas passagens que consideramos interessantes na caracterização do mouro na epopeia, e, com a ajuda de um aporte teórico a respeito dos muçulmanos, intentamos expor como esse povo é incutido no poema e como sua (des)construção é formada. Para tanto, apresentamos algumas considerações sobre Camões, a obra Os Lusíadas, um breve histórico sobre os mouros e, por fim, a descrição deles na obra. Não pretendemos, com este trabalho, esgotar o assunto em questão, mas instigá-lo e trazê-lo à esteira das discussões, uma vez que o estudo da identidade muçulmana na literatura ainda é pouco analisado.

\section{CAMÕes, os lusíadas e a GRANDIOSIDAde do povo PORTUGUÊS}

Nascido em Lisboa, por volta de 1525, provindo de uma família de condições medianas, foi Luiz Vaz de Camões o responsável por registrar e perenizar os grandes feitos do povo português. Seu conhecimento humanístico, não se sabe exatamente se obtido na Universidade de Lisboa ou de Coimbra, é transladado para sua obra, tornando-o, como afirma a crítica literária, o maior dos escritores de Portugal. Sua formação leitora é notável e facilmente percebida ao encontrarmos, em seus escritos, as várias referências à literatura antiga e moderna, à mitologia, à astronomia e a tantas outras áreas do conhecimento.

Navegante e expedicionário, Camões, Em Goa, participou de expedições do vice-rei D. Afonso Noronha contra o rei de Chembe, conhecido como 'o rei da pimenta', ao passo que pesquisou os costumes cristãos e hindus. Não foi só dessa expedição, no entanto, de que Camões fez parte.

Entre Fevereiro e Novembro de 1554 integrou a Armada de D. Fernando de Meneses, constituída por mais de 1000 homens e 30 embarcações, ao Golfo Pérsico. No regresso foi nomeado "provedor-mor dos defuntos nas partes da China" pelo Governador Francisco Barreto, para quem escreveu o "Auto do Filodemo". Regressou a Goa antes de Agosto de 1560 e pediu a protecção do Vice-rei D. Constantino de Bragança num longo poema em oitavas. Aprisionado por dívidas, dirigiu súplicas em verso ao novo Vice-rei, D. Francisco Coutinho, conde do Redondo, para ser liberto. Ao regressar ao reino, em 1568 fez escala na ilha de Moçambique, 
onde, passados dois anos, Diogo do Couto o encontrou, como relata na sua obra, acrescentando que o poeta estava a mingua e vivia graças a ajuda dos amigos. (SANTOS, 2008, p. 1)

A morte do poeta data do ano de 1580, após deixar um vasto e nacionalista legado literário. Enfim, acabarei a vida, e verão todos que fui tão afeiçoado à minha pátria que, não só me contentei de morrer nela, mas com ela (CAMÕES, 1996, p 17).

O que imortalizou Camões foi sua obra Os Lusíadas, poema épico que narra os grandes feitos do povo português. Para escrevê-la, Camões se inspirou em antigas obras, como as de Virgílio, Homero e de outros escritores clássicos. A obra é constituída de 10 cantos, com estrofes de 8 versos, utilizando rimas emparelhadas e cruzadas, e por versos de 10 sílabas métricas.

Os Lusíadas consiste principalmente de narração. É iniciado "In Media Res", ou seja, em plena ação. Vasco da Gama e sua frota se dirigem para o Cabo da Boa Esperança, com o intuito de alcançarem a Índia pelo mar. Na viagem, são auxiliados pelos deuses Vênus e Marte e perseguidos por Baco e Netuno. Na travessia, os heróis lusitanos passam por diversas aventuras, sempre comprovando seu valor e fazendo prevalecer sua fé cristã. Ao pararem em Melinde, ao atingirem Calicute, ou mesmo durante a viagem, os portugueses vão contando a história dos feitos heróicos de seu povo. Completada a viagem, são recompensados por Vênus com um momento de descanso e prazer na llha dos Amores.

O poema é estruturado através de uma narrativa principal, que, como dito anteriormente, apresenta a viagem da esquadrilha de Vasco da Gama. À narrativa principal é incorporada primeiramente a narração feita por Vasco da Gama ao rei de Melinde, na qual se conta a história de Portugal até a sua própria viagem. Pela voz de Gama são narrados os feitos dos heróis portugueses anteriores a ele, como Dom Nuno Álvares Pereira, o caso de amor trágico de Inês de Castro, o relato de sua própria partida, com o irado e premonitório discurso do Velho do Restelo e o episódio do Gigante Adamastor. Posteriormente, são acrescentadas as narrações feitas aos seus companheiros pelo marinheiro Veloso, que relata o episódio dos Doze da Inglaterra. Ao final, já na Índia, o irmão de Vasco, Paulo da 
Gama, conta ainda outros atos heróicos portugueses ao Catual de Calicute.

Ao narrar a grandeza do povo português, é possível percebermos a presença do inimigo, a quem os portugueses combatem e colocam em posição de inferioridade, trata-se do povo Muçulmano, de quem trataremos no próximo tópico deste trabalho.

\section{OS MOUROS: UM BREVE HISTÓRICO}

Foi no oriente médio que surgiu a civilização árabe ou islâmica, localizada em uma península desértica situada entre Ásia e África. Os árabes, até o século $\mathrm{VI}$, residiam em tribos, de forma descentralizada. No interior da península, havia tribos nômades de beduínos, que viviam basicamente do pastoreio e do comércio. Vez ou outra lutavam pela posse de algum oásis ou pelo comando de rotas comerciais, sobretudo o ataque a expedições que levavam materiais do Oriente para comercialização no Mar mediterrâneo ou no Mar Vermelho. Os árabes construíram cidades, com destaque para as construídas no oeste da Península Arábica, em especial a cidade de Meca, pólo comercial e religioso (RODRIGUES, 1980).

A religião desse povo era politeísta, os quais reuniam suas divindades em um templo denominado Caaba. Foi Maomé, contudo, que marcou a história povo árabe. Após atravessar o Egito, a Pérsia e a Palestina, tomando conhecimento de religiões como cristianismo e judaísmo, propalou uma visão que teve do anjo Gabriel, que the revelou a existência de um único Deus, Alá. Foi então que começou a pregar o Islamismo - a crença em Alá -, eliminando os outros deuses. As admoestações de Maomé, bem como toda a história, encontram-se no corão, o livro sagrado dos muçulmanos (RODRIGUES, 1980).

Com a expansão da fama de Maomé, os habitantes de Meca, com medo de perder o comércio que se alocava em Caaba, começaram a persegui-lo, ao passo que parte do povo árabe não aceitou seus ensinamentos, principalmente o monoteísmo. Maomé, nessa situação, fugiu para Latribe, hoje chamada Medina, dando início ao calendário muçulmano e aumentando cada vez mais o número de muçulmanos e sua expansão, alcançando o domínio da Península Arábica, 
a Índia, o norte da África e parte da Península Ibérica. A expansão do domínio do povo muçulmano molestou o comércio da Europa Ocidental com o Oriente, garantindo aos dominadores um grande progresso econômico e cultural. Com o sucesso, claro, vieram juntas as perseguições (RODRIGUES, 1980).

Os mouros são personagens presentes nos escritos cristãos, que se inicia no século VII, desde o surgimento do Islamismo. Teve início no ano de 711, com a chegada de um exército de soldados berberes que, atravessando o estreito de Gibraltar, empreendeu o início da conquista da península; terminou com sua expulsão de Granada, no século XV (BOECHAT, p. 301). A figura do mouro é carregada de estereótipos que o desfavorece e o coloca em posição inferior quando comparado aos outros povos e religiões. A presença do mouro aparece sobretudo em textos épicos, nos quais, ao ser narrados os grandes feitos de um determinado povo, o mouro é alocado, durante a descrição das batalhas, como inimigo e inferior. De acordo Amanda Azis Alexandre

É o que se observa em várias crônicas do período em questão. Embora pertençam a outro gênero que não o épico, nas batalhas narradas nas crônicas, tem-se a mesma matéria que compõe o épico, e sabendo-se que todas as práticas letradas do período são regidas pelas mesmas perspectivas, pode-se afirmar que o modo como os mouros são representados nelas não difere do modo como são apresentados no texto poético. (ALEXANDRE, 2010, p. 10)

Nos Lusíadas, durante as lutas do povo português em busca de território e propagação da fé cristã, é possível, de fato, identificarmos o epíteto pejorativo e de inferioridade que é conferido ao povo muçulmano. Sobre esta (des)construção do mouro, na epopeia, discorreremos no tópico que segue.

\section{A PRESENÇA DO OUTRO: A (DES)CONSTRUÇÃo DO MOURO EM OS LUSÍADAS}

A presença do mouro na epopeia já nos demonstra seu papel na sociedade portuguesa da época. A maioria das batalhas cantadas por Camões, no poema, está ligada, em sua maioria, a vitórias sobre os mouros. Borges (2007) salienta que 
A identidade portuguesa e sua heroicidade se constituem a partir de uma contraposição binária na qual toda a carga negativa recai sobre o oriental, principalmente o muçulmano, que expressa a síntese do ódio dos portugueses ao Outro: eram infiéis ao cristianismo e detinham o monopólio do comércio das especiarias (BORGES, 2007, p. 103).

Para compreendermos a presença dos mouros em Portugal e seu papel na epopeia camoniana, é preciso elucidar algumas considerações acerca da batalha de Ourique. O encontro (batalha de Ourique) se deu numa zona compreendida entre Leiria, Santarém e Cartaxo (FORTES, 1927, p. 28). Verónica Gomes apud Dicionário da Língua Portuguesa, nos diz que a Batalha de Ourique

Travou-se a 25 de Julho de 1139 entre D. Afonso Henriques e os muçulmanos, com vitória para o primeiro rei português. A tradição relata a vitória de $\mathrm{D}$. Afonso Henriques sobre um numeroso contingente muçulmano comandado por cinco reis. Modernamente a historiografia pensa que o exército muçulmano não seria tão numeroso, devido à situação de crise vivida pelos muçulmanos na Península e no Norte de África (GOMES, p. 2).

A batalha de Ourique, na épica, é narrada por Vasco da Gama após um pedido do rei Melinde a Gama para que narre os duelos entre cristãos e muçulmanos. O navegador narra, no $42^{\circ}$ estrofe do canto III, o seguinte:

Mas já o príncipe Afonso aparelhava

O Lusitano exército ditoso,

Contra o mouro que as terras habitava

De além do claro Tejo deleitoso;

Já no campo de Ourique se assentava

\section{O arraial soberbo e belicoso,}

Defronte do inimigo Sarraceno,

Posto que em força e gente tão pequeno.

Visualizamos, na narração de Gama, que os portugueses encontravam-se em menor número em relação aos mouros. Podemos interpretá-la não só como um fato, mas como uma técnica utilizada pelo narrador para mostrar que, mesmo com a força e número dos Sarracenos (mouros), os portugueses - assinalados - venceriam qualquer batalha. É narrada, ainda, no poema, uma ajuda dada aos 
portugueses, os quais se entusiasmam e lutam ainda mais. A ajuda é do próprio Cristo, que aparece ao rei D. Afonso Henriques, fazendo com que seus soldados o aclamem e resistam persistentemente até o fim da batalha - vencendo os mouros.

Ao narrar a batalha, no canto III $-47^{\circ}$ estrofe, o autor procede da seguinte maneira:

Qual os gritos e vozes incitado,

Pela montanha, o rábido moloso

Contra o touro remete, que fiado

Na força está do corno temeroso;

Ora pega na orelha, ora no lado,

Latindo mais ligeiro que forçoso,

Até que enfim, rompendo-lhe a garganta,

Do bravo a força horrenda se aquebranta:

Percebemos, na estrofe acima, a alusão que o narrador faz às touradas, igualando os mouros a touros, os quais, no ideário cristão, possuem, por causa do chifre, uma simbologia ligada ao demônio. É notória a animalização feita às figuras mouras, outra técnica utilizada pelo poeta para construir, intencionalmente, a identidade do muçulmano. O mouro, mesmos com os ataques, não revida e continua a lutar; no entanto "Pelos peitos as lanças Ihe atravessa / Uns caem meio mortos e outros vão / A ajuda convocando do Alcorão." E é dessa forma que surge o escudo de Portugal, que assinala o aparecimento de Cristo para os lutadores portugueses e a vitória sobre os mouros.

Na epopeia, há referência aos mouros, duas vezes, no episódio de Inês de Castro. É interessante observarmos mais uma técnica utilizada por Camões para construir o ideário mulçumano, uma vez que o inimigo é posto em sua obra num momento em que a epopeia toma vertentes mais líricas. Vejamos as estrofes em que ocorre: 
Tirar Inês ao mundo determina,

Por Ihe tirar o filho que tem preso,

Crendo côo sangue só da morte indiana

Matar do firme amor o fogo aceso.

Que furor consentiu que a espada fina

Que pôde sustentar o grande peso

Do furor Mauro, fosse alevantada

Contra uma fraca dama delicada?

E se, vencendo a Maura resistência,

A morte saber dar com fogo e ferro,

Sabe também dar vida, com clemência,

A quem para perdê-la não fez erro.

Mas, se to assim merece esta inocência,

Põe-me em perpétuo e mísero desterro,

Na Cítia fria ou lá na Líbia ardente,

Onde em lágrimas viva eternamente.

O episódio de Inês de Castro, embora retrate na epopeia um momento lírico, ao fazer referência aos Mouros, é possível notarmos que estes são encaixados em momentos de batalha como povos que devem ser combatidos. É interessante perceber como, até em momentos líricos da epopeia, a narrativa opera na construção do ódio a esse povo.

Um personagem mítico que aparece no decorrer da épica é muito importante para compreendermos a construção do Mouro nOs Lusíadas, sua colocação na epopeia e a forma como é feita representam mais uma técnica do poeta para a caracterização do muçulmano, dessa vez mostrando quem (e como) são os aliados do inimigo. Trata-se de Baco.

Baco (Dioniso), deus do vinho, era filho de Júpiter e de Semeie. Não representava apenas o poder embriagador do vinho, mas também suas 
influências benéficas e sociais, de maneira que era tido como o promotor da civilização, legislador e amante da paz (BULFINCH, 2002).

Baco aparece inicialmente no canto I, destaca-se na $97^{\circ}$ estrofe, na qual o autor narra a relação do Deus e dos Mouros, que, mesmo bastante ardilosos, não teme a forte gente - os portugueses:

Mas o mouro, instruído nos enganos

Que o malévolo Baco Ihe ensinara,

De morte ou cativeiro novos danos,

Antes que a Índia chegue, Ihe prepara.

Dando razão dos portos indianos,

Também tudo o que pede Ihe declara,

Que, havendo por verdade o que dizia,

De nada a forte gente se temia.

É Baco quem arma as ciladas contra a armada de Vasco da Gama. No decorrer da narração, Baco induz a todo tempo os mouros e incita-os a atacarem os portugueses. Baco, na epopeia, é mostrado como um vilão, o qual quer destruir os barões assinalados com suas armadilhas sujas. Essa é mais uma técnica do poeta de construir uma imagem deturpada dos mouros, através de outra construção, a da figura de um Deus que os ajuda.

A identidade muçulmana, (des)construída no decorrer da narração, perpassa por várias vertentes, algumas das quais aparecem reiteradamente nos cantos. Podemos citar, por exemplo, na caracterização do mouro, a família e a origem; a nação da qual fazem parte - dando ênfase em sua presença junto aos povos sarracenos, turcos, africanos e outras nações.

Outro aspecto, na referência aos mouros, é quanto à sua Lei, que, no poema, se refere principalmente à lei religiosa. O poema é construído por Camões de modo a superiorizar a religião cristã e inferiorizar a religião islã. Aqueles que nasceram na religião pregada por Maomé já se iniciam no pecado, na perfídia; e devem, pois, converterem-se ao cristianismo. 
Em relação à instrução dos mouros, a visão é de que esse povo é "bárbaro", ou seja, não possui educação alguma, tampouco civilização. Nesse sentido, podemos entender essa visão do muçulmano como mais uma técnica utilizada para edificar o conhecimento e a sabedoria do português, podendo ser um dos motivos pelos quais sempre saíam vitoriosos das batalhas contra os mouros.

Embora sejam conferidos aos muçulmanos epítetos injuriosos frequentemente na narrativa, há duas personagens às quais são atribuídos louvores: "O rei de Melinde e Monçaide. Àquele chama de "pagão benigno" (VI,3) e a este de "Mauritano sábio" (VIII,1). Os dois são elogiados devido aos serviços que prestaram aos portugueses. Monçaide é, inclusive, convertido ao cristianismo" (ALEXANDRE, 2010, p. 58).

Não só nas passagens citadas podemos encontrar a presença da construção da identidade muçulmana, mas em todo o poema. Ao mencionar alguns lugares, na construção do espaço em que se passa a narrativa, o poeta coloca a figura moura em alguns deles. Podemos destacar sua presença em Moçambique, Mombaça, na Batalha de Ourique - à qual já nos referimos anteriormente -, na Batalha de Salado e, por fim, em Calecute.

Ao apresentar, narrar e construir uma identidade de que não se faz parte, principalmente sendo ela uma nação inimiga, o poeta traz uma visão deturpada e, como vimos, na medida em que atua na inferiorização do inimigo, atua também na edificação e superiorização de sua identidade (portuguesa). Sendo assim, é necessário que leiamos o poema como leitores sagazes, pertinazes na descoberta das técnicas utilizadas pelo autor, para que entendamos de fato o que se deseja e o que está por trás de cada palavra.

\section{CONSIDERAÇÕES FINAIS}

Por meio do recorte de algumas passagens da epopeia camoniana apresentadas até aqui, podemos ratificar de que modo é (des)construída pejorativamente a figura do muçulmano. Para a realização dessa construção, conforme vimos, Camões apresenta - em sua visão - os principais defeitos de seu inimigo, 
atribuindo a eles a pusilanimidade e a aleivosia como principais características.

Ao apresentar a figura do mouro na épica, podemos concluir que a demarcação de inferioridade do inimigo é uma das principais técnicas utilizadas pelo poeta para alcançar o objetivo principal de sua obra, isto é, expor as vitórias do povo português. Para que os grandes feitos sejam exibidos, é necessário alguém a quem recaia a derrota, a inferioridade, e o poeta utiliza principalmente a figura do outro - muçulmano.

O poeta é muito eficaz no que se propõe a fazer, e para isso utiliza da mais sagaz retórica, elaborando um plano discursivo que induz o leitor a pensar como ele. A argumentação, os fatos que são apresentados, principalmente aqueles ligados à religiosidade, fazem com que o leitor se envolva na narrativa de modo a "escolher", ou melhor, ver o inimigo como seu inimigo e, assim, construir uma imagem deturpada deste.

Ao final deste ensaio, podemos pensar na figura do leitor e do autor de um texto; como, muitas vezes, somos irrompidos, involuntariamente, em uma opinião transmitida pelo discurso ardiloso do escritor.

\section{REFERÊNCIAS}

ALEXANDRE, Amanda Azis. O "torpe Ismaelita cavalleiro": um estudo sobre a presença dos mouros em Os Lusíadas. Dissertação de Mestrado. USP, São Paulo, 2010.

BORGES, Telma. A casa portuguesa: Cristãos conquistadores em O último suspiro do mouro, de Salman Rushdie. In: Histórias, imagens e narrativas. Disponível em: <http://www.historiaimagem.com.br/edicao4abril2007/ultimosuspiro.pdf> Acesso em: 10 de Novembro de 2015.

BOECHAT, Virgínia Bazzeti. A quantas gentes vês porás o freio: o outro n'Os Lusíadas. In: Revista Forma Breve, n. 5, 2007. p. 289-306.

BULFINCH, Thomas. O livro de ouro da mitologia: histórias de deuses e heróis. Rio de Janeiro; Digital Source, 2002. 
CAMÕES, Luís de. Os Lusíadas. Portugal: Europa-América, 1997.

CAMÕES, Luís de. Lírica. 1996.

FORTES, José Maciel Ribeiro. A Batalha de Ourique. Pôrto, 1927.

GOMES, Verônica. Um mito, um rei, uma bandeira: a batalha de Ourique e o símbolo da identidade nacional. Disponível em: <http://estudosculturais.com/ congressos/europe-nations/pdf/0007.pdf> Acesso em: 10 de Novembro de 2015.

RODRIGUES, Manuel Augusto. O mundo árabe e islâmico. "Nação e Defesa". Universidade de Coimbra, $\mathrm{n}^{\circ} 14,1980$.

SANTOS, Juliana Oliveira. Camões, o renascimento e Os Lusíadas. In: III Jornada Nacional de Linguística e Filologia da Língua Portuguesa. Rio de Janeiro, 2008. Disponível em: <http://www.filologia.org.br/iiijnlflp/textos_completos/pdf> Acesso em: 08 de Novembro de 2015. 
doi $10.48209 / 978-65-89949-16-0$

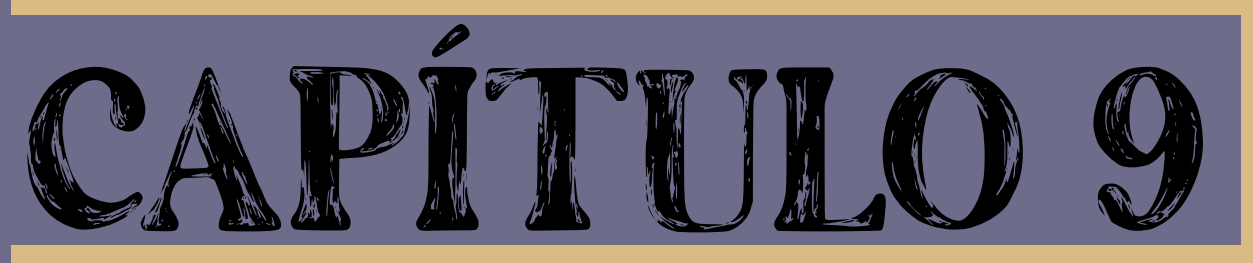

\section{A VIDA NUA EM "MINEIRINHO" DE CLARICE LISPECTOR THE NAKED LIFE IN "MINEIRINHO" BY CLARICE LISPECTOR}

Maria da Luz Lima Sales Dianily de Almeida 


\section{INTRODUÇÃO}

O conteúdo do conto ou crônica "Mineirinho", de Clarice Lispector, apresenta basicamente uma descrição angustiante diante da crueldade da execução de um criminoso, descrição essa que ocorre durante todo o enredo, expondo os sentimentos e emoções a respeito dos efeitos provocados pela morte de um simples bandido foragido da justiça. A forma como o narrador clariciano traduz as sensações diante do impacto de tamanha atrocidade leva o leitor a se questionar a respeito da Justiça e da forma como encaramos o Outro, sobre a ética e as relações sociais as quais podem ser bastante conflitantes.

Como enredo, uma notícia de jornal que choca a sociedade e provoca uma celeuma. A maioria quer o bandido Mineirinho morto, pois assim não daria mais trabalho à polícia. Mas será que o marginal mereceria os treze tiros? É o que o conto nos leva a refletir. Não estaríamos nos vingando em somente um homem com o ódio que todos sentimos por suas maldades, esquecendo a história de vida desse e de tantos mineirinhos espalhados pelo Brasil, que não têm a oportunidade de ser amados e bem criados? Questões como essas nos levaram ao filósofo Giorgio Agamben (2007) e a outros que, como grandes tradutores da pós-modernidade, nos ajudam a enxergar fenômenos que entrevemos na sociedade e que são continuamente encontrados em personagens da literatura tanto brasileira quanto universal.

Recorreu-se também a filósofos como à norte-americana Susan Sontag (2003), que mostrou em uma de suas obras (2003) os horrores de fotografias de guerras e outros menos citados aqui, como Michel Foucault (2001) que denomina os monstros de nossa sociedade, abordando a punição e os mecanismo de poder sobre os corpos; Hannah Arendt (1999) e sua banalização do mal, que, de origem judia, viveu o antissemitismo na pele. Agamber e tantos outros estudiosos tecem suas teorias acerca de fatores muito conhecidos por nós, vistos exaustivamente pela mídia, através de imagens repetidamente veiculadas a tornarem a dor do Outro algo comum, dessensibilizando-nos. 
Os treze tiros com que a polícia executou Mineirinho - e causa de suplício para o narrador do conto-crônica, a cada um ecoado - representariam um exemplo aos outros "mineirinhos", para que se emendem ou desapareçam na terra. Uma justiça às avessas para derramar neles, com o máximo de fúria possível, o ódio que a sociedade dita de bem sente pelos marginalizados e mais contra os rebeldes, que persistem em fugir da "justiça". Estes, com uma "vida nua", reforçam a necessidade de se controlar ou de punir exemplarmente o "mal", como método eficiente de domesticar os mais insurgentes.

Já no início de seu livro, Agamben (2007) discursa sobre duas existências possíveis: a vida nua - desprovida do sentido político, na qual a reflexão está ausente - e a vida qualificada, circunscrita à outra parte da humanidade, a qual tem direito de se alimentar, vestir-se, a uma boa educação, segurança, trabalho digno e a tudo o que construímos em nossas mentes com o sentido de cidadania. Inspirado nos gregos antigos para fundamentar sua teoria, precisamente em Aristóteles, em cuja Política escreveu que o propósito para todos os homens é "viver segundo o bem" (AGANBEN, 2007, p. 10), o filósofo italiano nos leva a questionarmos sobre ambas as perspectivas, enquanto nós nos baseamos no conto clariciano para estudá-lo.

Inicialmente, distinguiremos o conto da crônica para situarmos a narrativa clariciana em um gênero literário condizente com o sentido ontológico que ela comporta. Depois entraremos no tema propriamente dito, isto é, a violência que chega à crueza sem medida, perpetrada principalmente contra o lado mais fraco: órfãos, pois Mineirinho não tinha pai (ROSENBAUM, 2010), pobres, negros da periferia, sendo eles criminosos ou não, pois ao sistema de poder esse detaIhe não interessa muito, mas sim que tais seres, considerados inferiores, devem mesmo ser eliminados.

\section{AFINAL, A NARRATIVA CONSTITUI CONTO OU CRÔNICA?}

Clarice Lispector foi uma escritora tão moderna que subverteu conceitos da teoria literária, demolindo os de crônica e de conto, com sua narrativa heterogê- 
nea, pouco usual e publicando "Mineirinho" ora como o gênero crônica em Para não esquecer (LISPECTOR, 2020), ora como o outro (LINO, 2020). Ela publicou esse conto em 1962 como crônica na Revista Senhor, afirmando que o tal bandido "era devoto de São Jorge" (GOMES, 2020, p. 37) e que este era um de seus textos preferidos. Em 2015, o conto foi novamente publicado com ligeiras diferenças. Sua obra literária é aberta e complexa o suficiente para não se encaixar em compêndios que ensinam e ditam o que, por natureza, apresenta-se volátil como a liberdade e que faz parte das duas faces que integram inseparavelmente o fazer poético: forma e conteúdo.

O conto "Mineirinho" inicialmente pode ser classificado como crônica, posto ser um texto que comenta um fato ocorrido em um dia fixado na vida real, largamente explorado pela imprensa, o que aproxima o gênero da História pelo conteúdo centrado na realidade. De origem grega (chrónos), a palavra crônica, que significa tempo, indicava, segundo Moisés (1988, p. 245), "no início da era cristã, uma lista ou relação de acontecimentos ordenados segundo a marca do tempo", registrando os fatos históricos mas sem aprofundá-los.

A partir do século XIX, a crônica passa a ter status literário, perdendo sua característica de historieta, sendo veiculada em jornais e revistas, transformando-se até hoje em gênero literário tal qual o conto (a novela e outros), graças a autores como Carlos Drummond de Andrade, Rubem Braga, Fernando Sabino, apenas para citar três, que a elevaram ao mais alto grau de densidade e tensão, tornando-a um verdadeiro conto, ou seja, atemporal. É o caso de "Mineirinho", crônica que pode ser considerada um conto, apesar de apresentar uma simples notícia de jornal e trazê-la para uma reflexão humanística e filosófica cada vez mais atual.

Em entrevista a Julio Lerner, datada de 1977 (ano de sua morte), na qual a escritora demonstra sua preferência por "Mineirinho" como um conto e não uma crônica, Clarice afirma, com acentuada sensibilidade, que bastaria uma bala para matar o bandido, "[...] O resto era vontade de matar" (LINO, 2020, p. 96 [grifos nossos]). Nesse momento, referia-se à força policial brasileira, pouco profissional 
- mas que a representa profundamente - e que se deixa levar por sentimentos brutais contra os delinquentes a quem persegue com desejo de matar. Mostra, nesse conto, que a polícia não deseja seguir a justiça oficial, mas vingar-se na pessoa que muitas vezes é uma vítima da sociedade tão desigual onde esta é engendrada.

Um tema rico quanto esse eleva a crônica ao patamar de conto, abandonando a circunstância temporal para se tornar atual e universal. Não se trata mais de um bandido que fora morto pela polícia, mas de uma vítima, na condição de órfão, conforme destacou o narrador, negro, pobre, da periferia, com todas as carências imagináveis e que o narrador inclui em um "nós" solidário - "nós o queríamos vivo" (LISPECTOR, 2015, p. 2019) -, fugindo a um "eu" indiferente, e já no início da narrativa confessa sentir dor com sua morte, mesmo ele sendo um facínora.

Diferente da crônica, o conto é uma narrativa literária que conta uma trama com poucas personagens (às vezes somente uma) e apenas um conflito. Trata-se de uma das formas literárias mais antigas, senão a de maior antiguidade de que se tem conhecimento, juntamente com a fábula, o apólogo e a parábola (COELHO, 2010). Endereçado a adultos e crianças, às vezes breves como os contos de fadas; às vezes longos e dramáticos como "A Metamorfose", de Kafka; tais histórias fascinam e comovem pela sabedoria que encerram ou simplesmente divertem pela leveza e humor inteligentes.

Lendo-a, hoje, a narrativa de Lispector abandona o caráter anacrônico - de simplesmente um fato usual, uma crônica da imprensa - para atingir o estatuto de obra imortal, uma vez que traz para o debate o tema da vida e da morte, do que seja a justiça humana e divina, do que se oculta na sociedade, questionamentos que exercem no leitor um mergulho em meandros obscuros e não confessados, propiciando-Ihe que saia de si mesmo e alcance a dor do Outro em sua mais funda perspectiva. Já não temos mais um comentário acerca da notícia de jornal de um assassino perigoso após fugir do Manicômio Judiciário (GOMES, 2020), mas da vítima de um sistema desigual que se vinga nele, alguém que, desde nascença, nunca teve oportunidade de tornar-se um ser humano melhor. 


\section{A RECRUDESCÊNCIA DA VIOLÊNCIA CONTRA O MAIS FRACO, PRINCIPALMENTE QUANDO TEM A VIDA NUA}

A narrativa inicia-se expondo sobre os motivos pelos quais a sociedade sente uma revolta gigantesca pela morte daquele que seria um marginal foragido da polícia e a condição de criminalidade na qual Mineirinho se encontrava dava amostras de que era alguém perigoso para a sociedade. $O$ ato pode diagnosticar a sensação de insegurança das pessoas diante do número elevado da delinquência fazendo com que estas estejam sempre em estado de alerta. Apesar disso, temos uma situação na qual vários crimes foram pagos com outro crime. Ao menos é dessa forma que toda a situação é representada na obra literária.

A maneira como Clarice Lispector inicia a narrativa expõe uma dicotomia: de um lado temos um homem que oferece perigo para a sociedade e, de outro, uma narradora que se mostra extremamente revoltada com o assassinato contra ele. O modo como se narra, pausada e detalhadamente o que ela chama de "fuzilamento" de um criminoso, é um dos elementos que mostram o posicionamento empático do narrador em relação ao trágico lance noticiado nos jornais.

Gota a gota, os tiros que ele descreve angustiam o leitor mais sensível, fazendo-o questionar o papel da lei que se abate de forma furiosa, quase "justiceira", sobre aquele que funcionaria, nesse momento, como um estranho bode expiatório - estranho porque Mineirinho cometera realmente vários delitos - e reuniria assim como que todos os males da sociedade em um ser só:

Esta é a lei. Mas há alguma coisa que, se me faz ouvir o primeiro e o segundo tiro com um alívio de segurança, no terceiro me deixa alerta, no quarto desassossegada, o quinto e o sexto me cobrem de vergonha, o sétimo e o oitavo eu ouço com o coração batendo de horror, no nono e no décimo minha boca está trêmula, no décimo primeiro digo em espanto o nome de Deus, no décimo segundo chamo meu irmão. O décimo terceiro tiro me assassina - porque eu sou o outro. Porque eu quero ser o outro. (LISPECTOR, 2020, p. 178).

Podemos fazer um estudo comparativo entre o postulado por Clarice Lispector em "Mineirinho" e as considerações de Giorgio Agamben sobre o Homo Sacer. Em uma das leis romanas sobre direito criminal apresentada, ele constata 
uma contradição sobre a consideração do homem que, de uma lado, aprova a pessoa como um ser sagrado, "autoriza (ou, mais precisamente, torna impunível) sua morte" (AGAMBEN, 2007, p. 79). Ou seja, quando a justiça torna a morte de alguém inimputável ou não punível, permite e consente o crime, o que o narrador clariciano chama de "crime particular". Com a impunidade diante de uma violência, o crime constitui a contraposição dos códigos penais, pois dever-se-ia considerar toda pessoa um ser sagrado, e isso, como um pré-requisito para a garantia do direito à vida e à justiça.

O narrador da história expõe intensamente tais cenas: o assassinato do protagonista, que, na vida real, chamava-se José Miranda Rosa (GOMES, 2020, p. 37), alvejado com treze tiros pela polícia, mostra a realidade de uma desumanização do ser e um recrudescimento do ódio contra alguns segmentos mais enfraquecidos da sociedade. Referimo-nos ao posicionamento do narrador que, independentemente dos crimes que tenha cometido o homem, a justiça que o trucida deixa de ser Justiça e passa a ser criminosa.

As considerações de Macróbio, escritor romano da Antiguidade reportado pela filosofia agambeniana, apontam para as divergências da sacralidade humana, da violência como forma de desrespeitar o sagrado. Temos, no conto, o trecho que considera as relações de caráter divino para com a forma como a sociedade visualiza a violência: "Já era tempo de, com ironia ou não, sermos mais divinos; se adivinharmos o que seria a vontade de Deus é porque adivinhamos em nós a bondade, aquela que vê o homem antes de ele ser um doente do crime" (CLARICE, 2015, p. 220 [grifos nossos]). Neste trecho, a autora aborda a respeito da necessidade de um olhar mais divino ou humanístico para fazer considerações a respeito do fuzilamento de Mineirinho. Esta visão divina, provavelmente parecida com as características atribuídas à figura de Deus como um ser indulgente e misericordioso, é almejada no conto.

A forma como a criatura humana pode chegar ao mais baixo nível de humanidade e acabar por se tornar um delinquente deve ser levada em conta, pois a todo instante o leitor é induzido a fazer essa reflexão sobre os crimes de 
um homem que não são a substância que o constituem. Havia outro Mineirinho em Mineirinho. Dessa forma, a narrativa conduz o interlocutor a não se ater apenas aos delitos de José Rosa e esta deve ser a verdade em que deve basear-se toda e qualquer justiça social.

Quando o indivíduo coloca-se em um posicionamento que olha para o Outro com empatia, o resultado poderá ser o seguinte pensamento: devemos querer que ele viva, assim como queremos nós viver. Este é o apontamento mais gritante durante toda a leitura do conto "Mineirinho", criminoso ou honesto, era um ser humano e como tal teria direitos e deveres. Cumprindo os deveres ou não, é tão humano quanto qualquer outro ser. O narrador critica uma justiça que perde sua característica primordial e passa a cometer um crime particular.

No livro que escolhemos para principal base teórica, Agamben (2007) designa o homo sacer conforme o próprio ser humano que, se antes se encontrava sob a tutela divina como sua criatura, à imagem e semelhança de Deus, agora se compreende como alguém sob a égide do Estado. Por isto a questão da política está relacionada com o homo sacer, tema caro ao filósofo. Estas mudanças de esfera estão relacionadas à própria vida nua, ou seja, o homo sacer como criatura. Este se encontra em constante mudança, em perpétuo nascimento, posto que o homem está em contínua metamorfose. A vida nua, por sua vez, é um constante abandonar-se, pois ela transita entre o animal e o político, não se fixando em nenhuma das duas, pois a vida nua é dupla. Temos aqui um conflito entre o animal e o político, âmbitos distintos que compõem o homo sacer.

Ou sobrevive-se como um animal simplesmente, ou vive-se uma vida digna e politicamente qualificada, o viver bem (AGAMBEN, 2007), isto é, a política torna o viver algo mais, intensificado pelo acréscimo do advérbio "bem". Quando não se tem o privilégio de possuir uma boa vida é porque ela é nua. Uma vida qualificada constitui a dos que têm direito à linguagem, ao discurso, à educação e a tudo o mais. A outra representa o oposto, aqueles que, despossuídos, não são ouvidos ou nunca falam. Entretanto e paradoxalmente, a vida nua não se restringe apenas a um aspecto, uma vez que é impossível manter-se estanque, os indivíduos caminham entre um lado, de alienação; e outro, de vida mais plena. 
O filósofo Agamben (2007) aborda também, insistentemente, acerca do estado de exceção, o qual constitui um período de manutenção da ordem para o soberano - ou ditador - e sua comunidade estado cuja lei é subvertida incongruentemente. A lei é para o Outro e não para quem a determina. O que se processou com o bandido Mineirinho, segundo revela o narrador do conto, aproxima-se ao que o pensador expôs em seu livro. A lei foi executada mesmo infringindo-a.

Abre-se um parênteses para atentarmos à origem do vocábulo bandido, condição de nosso protagonista, o qual é derivado de bando. Agamben, reportando-se a uma sugestão de outro filósofo, Jean-Luc Nancy, revela que a palavra "bando" origina-se de um "antigo termo germânico que designa tanto a exclusão da comunidade quanto o comando e a insígnia do soberano" e ainda: quem "foi banido não é, na verdade, simplesmente posto para fora da lei e indiferente a esta, mas é abandonado por ela", afinal o protagonista de Clarice foi "exposto e colocado em risco no limiar em que vida e direito, externo e interno, se confundem" (AGAMBEN, 2007, p. 36 [grifo do autor]).

Ainda a respeito da vida nua, o filósofo nos fala desta como sendo desqualificada, porquanto não merece ser digna de existir, é sumariamente descartada e descartável. E assim como um soberano, que instaura o estado de exceção ao rasgar as leis que regem uma nação (a Constituição) e se arvora o direito de suspender a ordem antes vigente, coloca-se como um fora da lei. Agamben (2007) cita as palavras de Carl Schmitt para explicar o pensamento do soberano que, estando apartado da lei (é um fora da lei), mas declara não existir um fora da lei.

Toda essa construção a respeito da humanização e do ser constrói para o leitor uma imagem mental de angústia e revolta pelos fatos decorridos no conto. O narrador dispõe como sente a dor pelo Outro, pela morte deste. A filósofa Susan Sontag traz como tema de um de seus livros (2003) o horror da violência cometida nas guerras razoavelmente recentes, em fotografias que expõem a barbárie de que são cada vez mais capazes a mídia e a sociedade como um todo. Em alguns aspectos, seu livro retoma o que sente o receptor da narrativa em estudo.

O trabalho de Sontag nos lembra o que Agamben (2007) nos diz a respeito daquilo que experimentamos diante das imagens hodiernas na sociedade do 
espetáculo - a reificação que ela provoca (DEBORD, 2003) em uma época de banalizar o mal (ARENDT, 1999) - e o poder da mídia, imperando ubiquamente todos os contextos a transformar o poder em variadas esferas. Para a primeira filósofa, as pessoas creram por muito tempo que o terror sentido com a contínua visão de cenas horripilantes de violência poderia ensiná-las sobre o horror e a loucura que é a guerra (SONTAG, 2003).

Na prosa clariciana, temos o horror muito bem representado por uma crônica inspirada em fatos que aconteceram na realidade. Exatamente esse o ponto que abordamos enfaticamente no tecer literário de Clarice Lispector, a construção de sua narrativa faz com que o leitor obtenha uma imagem mental bastante nítida a respeito da sensação terrificante que provoca o fuzilamento de Mineirinho, explorado com estardalhaço pela mídia à época (REZENDE \& OLIVEIRA, 2020, p. 140).

Idêntico se vê - o ocorrido com o "caso Mineirinho", com a imprensa sensacionalista pondo as imagens do protagonista morto - ao que Sontag (2003) versa, da espetacularização nas fotografias de guerra. Não vemos, necessariamente, uma guerra, mas temos a nítida visão sobre qual a sensação de estar diante de uma injustiça social. Fica clara, portanto, a forma como Lispector encara a vida do ser humano e quais são as condicionalidades da manutenção desta. Tudo parte da premissa de que se eu vivo e tenho o direito à vida, o outro também possui o mesmo privilégio. A manutenção da vida é algo indiscutível, embora, como mencionado antes, deve concernir mesmo a um criminoso, alguém que está à margem da sociedade, e sua humanização não deveria ser discutida.

Sontag expõe serem a banalização da vida do outro e o morticínio premissas a favor da degradação humana chamada por ela de guerra. Ela ainda argumenta que as pessoas costumam crer "que o certo está de um lado e a opressão e a injustiça estão do outro, e de que a luta precisa prosseguir, o que importa é exatamente quem é morto e por quem" (SONTAG, 2003, p. 27). O pensamento sontaguiano associa-se ao conto e à sua mensagem. De um lado temos um narrador pertencente a uma classe financeiramente privilegiada e esse entendi- 
mento aparece ao leitor quando aquele (pois se trata de narrador personagem) pergunta à sua empregada sobre os fatos jornalísticos amplamente alardeados. Do outro lado, temos um facínora, morto de forma cruel. Apesar da vida de crimes, a morte desse homem, com os maiores motivos para ser odiado por todos, causa revolta em quem provavelmente desconhece a realidade, tampouco a que o rebaixara ao nível da sub-humanidade.

No texto literário, sempre vamos perceber a tríade autor, texto, leitor como via intimamente ligada, provocando uma kátharsis (do grego purgação ou purificação), "processo de identificação que leva o espectador a assumir novas normas de comportamento social", mas tal concepção se alarga para "o prazer afetivo resultante da recepção de uma obra" a qual transforma as convicções deste leitor, libertando sua mente (ZILBERMAN 1989, p. 57). Cada texto literário é recriado por quem o lê, pondo nele suas vivências, acrescentando imagens novas, saídas de seu íntimo e que o autor sequer sonharia, porque cada leitura traz descobertas frescas. O panorama da obra ficcional revela a dualidade entre realidade $e$ imaginação "Ordem versus desordem, habitual versus inabitual, a construção de um mundo versus o combate contra essa construção" (UNES, 2003, p. 11). Dessa forma, a narrativa de Clarice, baseada em fatos reais, aponta para a realidade a ocorrer até nos dias atuais.

O próprio gênero crônica é constituído de narrativas de fatos atualizados pelo escritor ou jornalista, que envolvem o cotidiano deste com detalhes que ele pode observar no seu dia a dia. O que inferimos sobre isso é que nos parece que tal cotidiano se manifesta de uma forma deplorável e que esses tipos de notícias abomináveis fazem parte do nosso presente por apresentarem o espetáculo que o leitor de internet, jornais ou o telespectador de telejornal gosta de consumir.

Os únicos fatos relacionados a um mundo imaginário, no conto de Clarice, são as sensações e emoções que ela transmite ao longo do texto, e tanto a paixão da escritora quanto a revolta percebem-se ao longo de sua construção. O que vai veiculado nele não se trata de apenas uma informação a ser decodificada e sim um padrão de interação na expressão de Zilberman (1989), isto é, na 
situação de regras que envolvem o receptor e dizem no que ele compete refletir e o que poderia fazer se se encontrasse naquela situação. Nesse viés é que encontramos na obra clariciana como se manifesta o posicionamento empático da escritora de "Mineirinho". As obras possibilitam a transmissão de mensagens diretas ao leitor, repassadas para que ele se aposse delas (ZILBERMAN, 1989).

A forma como o texto literário pode atuar sobre o leitor expressa-se de modo a fazer com que o escritor consiga levar o receptor a sentir diversas sensações transmitidas pela literatura. Esse fenômeno, de repúdio a tudo o que exagera o mundo pós-moderno, no trecho do conto-crônica visualiza-se em:

Eu não quero esta casa. Quero uma justiça que tivesse dado chance a uma coisa pura e cheia de desamparo e Mineirinho - essa coisa que move montanhas e é a mesma que o faz gostar "feito doido" de uma muIher, e a mesma que o levou a passar por porta tão estreita que dilacera a nudez; é uma coisa que em nós é tão intensa e límpida como uma grama perigosa [sic] de radium, essa coisa é um grão de vida que se for pisado se transforma em algo ameaçador - em amor pisado; essa coisa, que em Mineirinho se tornou punhal, é a mesma que em mim faz com que eu dê água a outro homem, não porque eu tenha água, mas porque, também eu, sei o que é sede; e também eu, não me perdi, experimentei a perdição (LISPECTOR, 2020, p. 220).

O trecho mostra como o narrador consegue sentir compaixão por Mineirinho, usando a analogia de dar de beber a outro porque sabe o que é sentir sede. Todos os aspectos citados revelam a capacidade humana de compartilhar a dor do Outro e colocar-se no lugar onde ele se encontra. Sentir o que o Outro sente, mesmo que haja inúmeras diferenças e compreender aspectos relacionados às emoções, revela um posicionamento no qual o Outro possui a mesma relevância que seu próximo.

Vemos um aspecto solidário nessa narrativa, mas também temos a sensação de impunidade enquanto lemos o conto. O leitor se aproxima desse Outro e isso é possível principalmente porque, conforme nos remete Sontag (2003, p. 34), "a violência é sempre injustificável, que a força está sempre, em todas as circunstâncias, errada" um vez que a violência é capaz de reduzir algo ou alguém a nada, coisificando-o, mesmo seres humanos e, nesse caso vivo, a forma como a justiça atuou sobre a condição do homem Mineirinho. 
Os atos de crueldade, cuja justificativa incide na vida de crimes do facínora, foram realizados de uma forma desumanizadora cada vez mais intensa. À vítima é negada à sua condição de ser humano e todo e qualquer direito que este possa ter, usando-se sempre sobre ela a negativa do direito à vida em uma tentativa de confundir a perversidade humana com uma dose a mais de perversidade. $O$ narrador lembra, neste trecho, que: "No entanto a primeira lei, a que protege corpo e vida insubstituíveis, é a de que não matarás. Ela é a minha maior garantia: assim não me matam, porque eu não quero morrer, e assim não me deixam matar" (LISPECTOR, 2020, p. 219), destarte, o que condiciona a manutenção individual da vida é inquestionável. Há uma regra implícita aí: não mato pois não quero morrer; mantenho minha vida, mas quero que a vida do outro seja mantida também.

Sontag ainda nos fala do discernimento que teríamos frente a cenas tão dolorosas quanto a abordada no conto no tocante a fotografias chocantes de atrocidades que "podem suscitar reações opostas. Um apelo em favor de paz. Um clamor de vingança", mas também a uma "atordoada consciência, continuamente reabastecida por informações fotográficas, de que coisas terríveis acontecem" (SONTAG, 2003, p. 35). Em Clarice, o narrador nos joga na cara que o protagonista, para ter sapatos, teve de roubar e matar e "que um homem que mata muito é porque teve muito medo" (LISPECTOR, 2015, p. 21), chegando a designar que Mineirinho e nós - todos os que estão do outro lado - somos lama viva.

Foucault considerou aquele que infringe as leis como um "anormal", uma espécie de aberração ou monstro, consoante fora Mineirinho, isto é, alguém que alia "o impossível com o proibido" (2001, p. 70), que caminha uma estrada de violações às leis, como se ele tivesse opção. Em Vigiar e punir (2013), o filósofo expõe as formas de exercer controle sobre os corpos de modo a se entender e definir as subjetividades. A tortura e a ameaça de morte - às vezes até o assassinato mesmo - constituem formas, sofisticadas ou não, de controlar o corpo a fim de que ele se discipline. 


\section{CONSIDERAÇÕES FINAIS}

A autora do conto "Mineirinho" mostra uma escrita polígrafa e, tratando sempre dos temas com grande sensibilidade, apresentou-nos um sujeito marginalizado, protagonista da narrativa e sua vida nua, ou sua personificação, o homo sacer, criatura que deveria ser considerada divina, como as demais vidas que compõem a sociedade, mas o que se viu foi a negação desta vida, causando revolta ao narrador/leitor numa narrativa que deixou as páginas de um revista dos anos sessenta do século passado para alcançar um caráter contemporâneo neste XXI, o qual põe a nu as mazelas de uma sociedade injusta e brutal principalmente contra segmentos desconsiderados.

Estes, exemplares do homo sacer e sua vida nua, já punidos desde o nascimento por serem destituídos de bens materiais e espirituais, de amor familiar e cuidados de que toda criança necessita, sofrem ao longo de uma vida áspera que dura até a morte, sendo eliminados pois seriam feios de se ver. Porém o narrador de Clarice abre-nos os olhos para esses tantos "mineirinhos" ao declarar que ele é o Outro, porque quer ser esse Outro. E sua indignação frente ao episódio macabro, ao assassinato de um marginal nos morros cariocas não poderia ficar impune, não ao leitor atento daquele ano de 1962, e a trajetória breve do bandido - viveu apenas 28 anos - não seria esquecida, ao contrário, em tempos hodiernos os "mineirinhos" são cada vez mais frequentes e os tiros que mataram aquele jovem continuam matando, aumentando a dose de violência desmedida.

O que temos na obra literária em estudo é o que Sontag nos faz visualizar, as coisas terríveis que nos são mostradas, em cores, a realidade atroz que, entretanto, não nos choca mais, o que pode levar o leitor do conto a construir mentalmente um cenário de horror sobre uma "guerra" diária, a morte de Mineirinho configurando-se como assassinato. O que se propõe aqui é que se estabeleça uma perspectiva dessa guerra, com todos os seus pesares e a consternação à qual os jovens "mineirinhos" de hoje são submetidos, sendo vitimizados durante abordagens policiais. 
A leitura de "Mineirinho" tem a capacidade de levar o interlocutor a um misto de reflexões intensas sobre a vida, justiça, criminalidade e marginalização. $O$ conto consegue o feito de transcender os limites que diferem os dois gêneros literários e patenteia a realidade que permanece como vida na pós-modernidade. Ainda hoje uma parcela considerável da sociedade encontra-se excluída tanto na vida quanto na morte. E a literatura mostra-nos como é a visão do mundo a respeito desses excluídos: necessidade de cidadania, valor básico de uma existência não nua.

A vida do homo sacer representa uma existência exposta, desprovida de guarida, sem contar com o mínimo. As condições sociais desfavoráveis proporcionam a marginalização de pessoas que ficam nos limítrofes de uma dualidade: os que estão nus no sentido político e os que possuem vestes salvaguardando a integridade humana. O ser sagrado do qual fala Agamben pertence ao caráter divino, tem hoje sua sacralidade abalada e consternada quando se trata da punição para um crime. O cenário encontrado na obra clariciana possui segmentos semelhantes: homem pobre, excluso e rechaçado pela sociedade e pela justiça.

A filosofia agambeniana ilustra que o ser humano pode ser condicionado à criminalidade, esquecido e abandonado pela nação, porém é lembrado pela lei inexorável na hora da punição. O narrador de "Mineirinho" mostra compadecimento para com aquele que foi postergado pela lei até o décimo terceiro tiro, não para negar desregramentos cometidos pelo homem, mas para enxergar sua humanidade. Ao contar cada um dos tiros desferidos contra o jovem facínora e descrever as emoções provocadas ao ouvi-los como se fossem no próprio narrador, provoca uma sensação que não nos sai da cabeça.

Por fim, o conto de Clarice transmite essa angústia e reflexão no ledor, que fica livre com suas ruminações para fazer suas próprias interpretações, isto é, a dor do outro não deve ser desconsiderada, não devem ser levados em conta estigmas sociais que nos embaracem a visão e a forma com a qual vemos essa dor. Posicionamentos empáticos como o que lemos na prosa modernista clariciana fazem com que reflitamos sobre ações e reações humanas e que os indivíduos 
reagem distintamente, uns têm seus corpos dóceis e outros não se vergam a nada. Estes são os que, dificilmente, aceitarão as regras impostas por uma sociedade tão desigual quanto a brasileira.

\section{REFERÊNCIAS}

ARENDT, Hannah. Eichmann em Jerusalém: um relato sobre a banalidade do mal. Trad. José Rubens Siqueira. São Paulo: Companhia das Letras, 1999.

AGANBEN, Giorgio. Homo sacer: o poder soberano e a vida nua. Trad. Henrique Burigo. Belo Horizonte: Editora UFMG, 2007.

COELHO, Nelly Novaes. Panorama Histórico da Literatura Infantil/Juvenil: das origens indo-européias ao Brasil contemporâneo. Barueri, SP: Manole, 2010.

DEBORD, Guy. A sociedade do espetáculo. Trad. Railton Sousa Guedes. Edição Geocities, 2003.

FOUCAULT, Michel. Os anormais: curso no Collège de France. Trad. Eduardo Brandão. São Paulo: Martins Fontes, 2001.

. Vigiar e punir. Trad. Pedro Elói Cascais. Biblioteca Nacional de Portugal, 2013.

GOMES, André Luís. Clarice Lispector: 13 títulos ou 13 tiros em três sopros de vida ou morte. Revista Cerrados, [S. I.], v. 29, n. 54, p. 36-44, 2020.

LINO, Patrícia. Algumas notas sobre a literatura a partir de Clarice Lispector ou algumas notas sobre Clarice Lispector a partir da literatura. In: COUTINHO, Fernanda; ALENCAR, Sávio (org.). Visões de Clarice: ensaios, entrevistas, leituras. Fortaleza: Imprensa Universitária, 2020.

LISPECTOR, Clarice. Todos os contos. 1. ed. Rio de Janeiro: Rocco Digital, 2015.

Para não esquecer. 1. ed. Rio de Janeiro: Rocco Digital, 2020.

MOISÉS, Massaud. Dicionário de termos Literários. São Paulo: Cultrix, 1988. 
REZENDE, Luciana Barreto Machado; OLIVEIRA, Edilberto Martins. Entre o direito de punir e a impossível redenção, o exemplar réquiem de Mineirinho. Revista Cerrados, [S. I.], v. 29, n. 54, p. 138-150, 2020.

ROSENBAUM, Yudith. A ética na literatura: leitura de "Mineirinho", de Clarice Lispector. Estudos Avançados, [S. I.], v. 24, n. 69, p. 169-182, 2010.

SONTAG, Susan. Diante da dor do outro. Trad. Rubens Figueiredo. 1. ed. São Paulo: Schwarcz, 2003.

UNES, Wolney. A estética da recepção - Hans Robert Jauss e Wolfganlser. Revista Estudos (Universidade Católica de Goiás), Goiânia, v. 30, n.4, p. 753-766, 2003.

ZILBERMAN, Regina. Estética da Recepção e História da Literatura. 1. ed. São Paulo: Ática, 1989. 


\section{SOBRE AS ORGANIZADORAS}

\section{RARLA MENEZES LOPES NIELS}

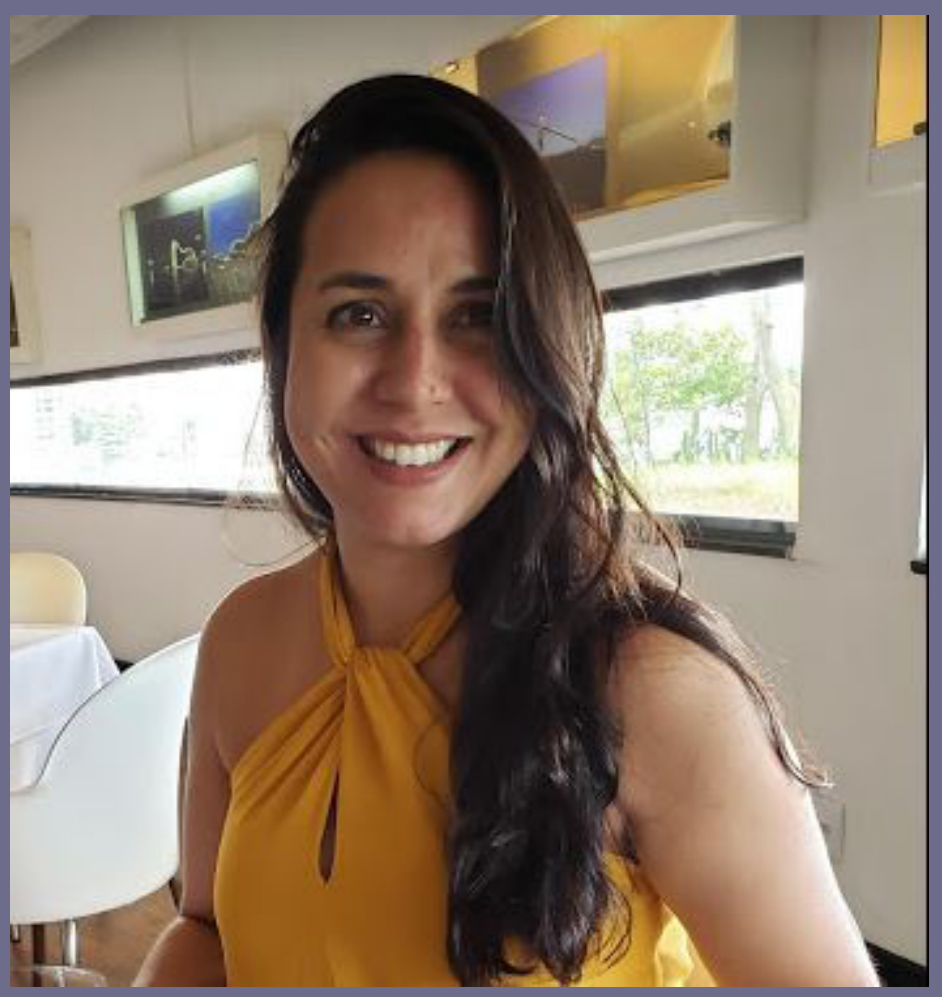

Doutora em Estudos de Literatura pela Universidade Federal Fluminense (UFF), mestra e graduada em Letras pela Universidade do Estado do Rio de Janeiro (UERJ). É professora substituta no Instituto Federal de Educação Ciência e Tecnologia do Rio de Janeiro (IFRJ), campus São Gonçalo, professora docente I na Secretaria de Estado de Educação do Rio de Janeiro (SEEDUC-RJ) e coordenadora de disciplina no Consórcio CEDERJ/UFF/UAB, atuando, respectivamente, no ensino médio e na graduação em Letras, nas áreas de Teoria da Literatura, Literatura Brasileira, Literatura Portuguesa e Língua Portuguesa. Seus interesses de pesquisa voltam-se, sobretudo, para o fantástico na literatura brasileira e para o ensino de literatura. Lattes: http://lattes.cnpq.br/9241571154601781

Orcid: https://orcid.org/0000-0002-3647-2427

E-mail: karla.niels@gmail.com 


\section{IZA REIS GOMES ORTIZ}

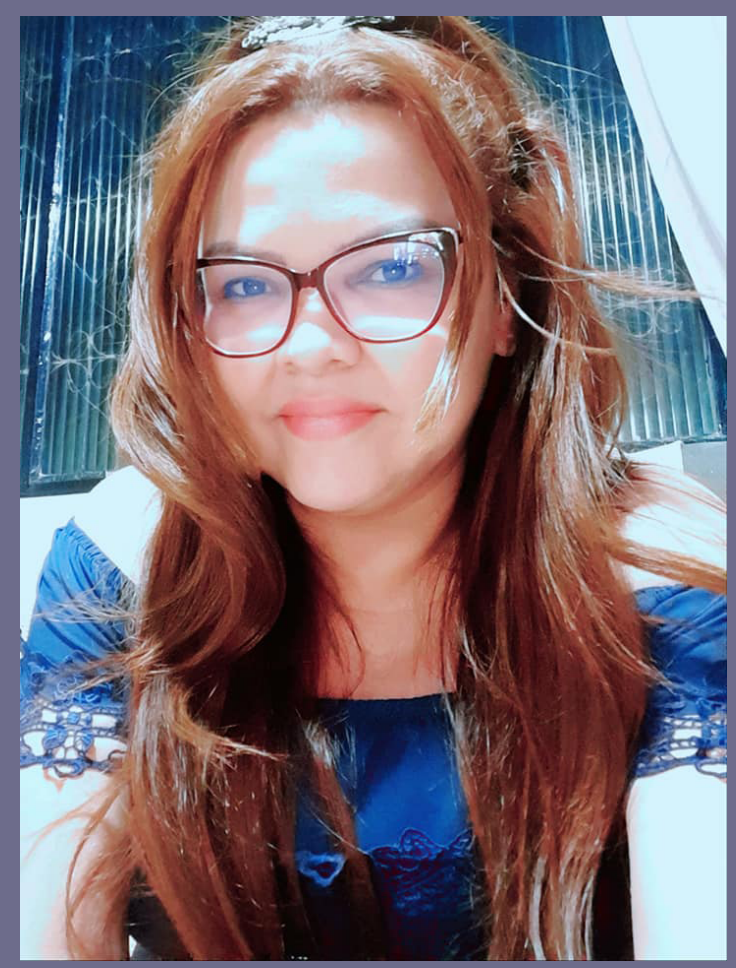

É professora de Língua Portuguesa e Literatura do IFRO - Campus Porto Velho Calama. Professora do Mestrado Profissional em Educação Profissional e Tecnológica em Rede Nacional - PROFEPT/IFRO; Professora credenciada do Programa de Mestrado em Estudos Literários da Universidade Federal de Rondônia - UNIR; Doutora em Sociedade e Cultura na Amazônia pela Universidade Federal do Amazonas - UFAM; Mestre em Letras - Linguagem e Identidade pela Universidade Federal do Acre - UFAC. Graduada em Letras/ Português pela Universidade Federal de Rondônia. Especialista em Letras - Estudos Literários e Linguísticos pela FACISA. Especialista em Metodologia e Didática da Educação Superior pela Universidade de Rondônia - UNIRON. Tem experiência como Avaliadora de projetos na área de Língua Portuguesa e Literaturas com ênfase em Teoria da Literatura, Letramento Literário, Processos de criação na Amazônia e Metodologias da pesquisa em gêneros acadêmicos como Artigos científicos e Projetos de pesquisa. No Mestrado do ProfEPT, realiza pesquisas na área das práticas educativas e estratégias interdisciplinares com a pesquisa como princípio pedagógico. $\mathrm{E}$ ainda elaboração e experimentação de propostas de ensino transformadoras em sala de aula e em outros espaços. No Mestrado em Estudos Literário, realiza pesquisas na área da Literatura Amazônica com ênfase em Letramento Literário, Análise literária e Processos de criação. Coordena o Grupo de Pesquisa Criamazônia/IFRO que trabalha com a Literatura em uma perspectiva estrutural, social e de criação.

Lattes:http://lattes.cnpq.br/7671303144200741

Orcid: https://orcid.org/0000-0001-8668-1692

E-mail: iza.reis@ifro.edu.br 


\section{MARLISE BUCHWEITZ RLUG}

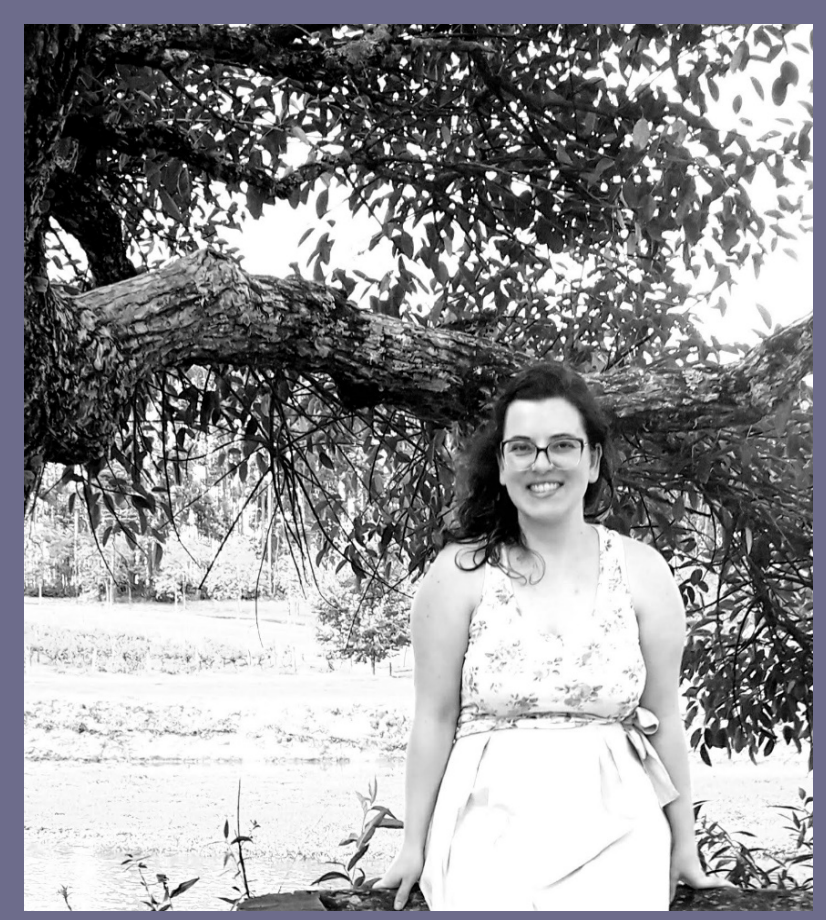

É escritora; revisora textual; pesquisadora; Doutora em Estudos Interdisciplinares/ Memória Social e Patrimônio Cultural (UFPel), Mestre em Letras/Estudos Literários (UFRGS), Especialista em Letras/Literatura Comparada (UFPel) e Graduada em Letras/Inglês e Literaturas (UFPel). Atua em pesquisas nas áreas de Literatura Comparada, Ensino de Língua e Literatura, Memória e Docência.

Lattes: http://lattes.cnpq.br/5429537417655258

Orcid: http://orcid.org/0000-0003-3581-9465

E-mail: marlisebuchweitz@gmail.com 


\section{SOBRE AS AUTORAS E AUTORES}

\section{Arthur Scapini}

Graduando em Letras Português - FURG. Atualmente, é bolsista do projeto residência pedagógica.

E-mail: arthur_scap@hotmail.com

\section{Analoren Fernandes}

Graduada em Letras-Português, na Universidade Federal do Rio Grande - FURG (2021) e mestranda em Letras, também na Universidade Federal do Rio Grande. E-mail: analorenfernandes@gmail.com

\section{Alexandre Ferreira da Costa}

Doutor em Linguística Aplicada pela Universidade Estadual de Campinas (2007). Professor da Universidade Federal de Goiás desde 1998 e atua na formação de professores. Líder do Grupo de Estudos Transdisciplinares e Aplicados à Formação de Educadores (GRUPO PORTOS - UFG/CNPq).

Contato: alexandrecostaufg@gmail.com.

\section{Dianily Moraes de Almeida}

Acadêmica do curso de licenciatura plena em Letras, Língua Portuguesa pelo Instituto Federal do Pará.

\section{Karla Menezes Lopes Niels}

Doutora em Estudos de Literatura pela Universidade Federal Fluminense (UFF), mestra e graduada em Letras pela Universidade do Estado do Rio de Janeiro (UERJ). É professora substituta no Instituto Federal de Educação Ciência e Tecnologia do Rio de Janeiro (IFRJ), professora docente I na Secretaria de Estado de Educação do Rio de Janeiro (SEEDUC-RJ) e coordenadora de disciplina no Consórcio CEDERJ/UFF/UAB, atuando, respectivamente, no ensino médio e na graduação em Letras, nas áreas de Teoria da Literatura, Literatura Brasileira, Literatura Portuguesa e Língua Portuguesa. Seus interesses de pesquisa voltam-se, sobretudo, para o fantástico na literatura brasileira e para o ensino de literatura. E-mail: karla.niels@gmail.com 


\section{Luciana Morais da Silva}

Pós-Doutora em Letras - Estudos de Literatura -Teoria da Literatura e Literatura Comparada - pela Universidade do Estado do Rio de Janeiro (2018). Doutora em Letras - Teoria da Literatura e Literatura Comparada - pela Universidade do Estado do Rio de Janeiro e Doutora em Letras - Literatura de Língua Portuguesa - pela Universidade de Coimbra, em regime de cotutela (2016). Atua como professora/tutora da Faculdade Unyleya. Participa do Grupo de Pesquisa do CNPq 'Nós do Insólito: vertentes da ficção, da teoria e da crítica'. Tem experiência na área de Letras, atuando principalmente nos seguintes temas: Estudos Narrativos; Insólito Ficcional; Mundos Possíveis; Memória; História; Personagem; Feminino; Preconceito; Mulher; Teoria e crítica literária, com artigos publicados nas respectivas áreas. E-mail: lulu_msilva@yahoo.com.br

\section{Márnei Consul}

Escritor e professor. Licenciado em Letras - Português/Inglês (UNISINOS) e especialista em Educação em Direitos Humanos (FURG), Educação para a Diversidade (UFRGS), Educação Ambiental (FURG), Gestão Escolar: Orientação e Supervisão (São Luís) e Língua, Literatura e Ensino (FURG).

E-mail: marneiconsul@hotmail.com.

\section{Mauricio Alves de Souza Pereira}

Graduado em Letras Português pela Universidade Estadual de Montes Claros UNIMONTES.

\section{Maria da Luz Lima Sales}

Doutora em Ciências da Educação pela Universidade de Évora (Portugal). Professora do Departamento de Letras e do Ensino Médio no Instituto Federal do Pará. Líder do Grupo de Estudos Literários e Linguísticos da Amazônia, atua em projetos que envolvem a literatura brasileira em geral e infantojuvenil, com ênfase na educação multicultural como facilitadora para aceitação da cultura indígena bem como da do Outro em nossa sociedade (projeto de cunho social e outro sobre a obra de Clarice Lispector). 


\section{Ricardo Costa de Sousa}

Professor na Fundação Universidade Federal de Rondônia - UNIR. Pós-doutor em Educação pela Universidade do Oeste de Santa Catarina. Lattes: http://lattes. cnpq.br/1114035420386099. E-mail: ricardoluter@gmail.com

\section{Rodrigo Milhomem de Moura}

Doutorando e Mestre pelo Programa de Pós-Graduação em Letras e Linguística da Universidade Federal de Goiás. Contato: milhomemmoura@gmail.com.

\section{Ruskaia Fernandes Mendonça}

Mestre em Educação pela Universidade Federal de Goiás (UFG). Graduada em Pedagogia pela UFG. Contato: ruskaia.fernandes@gmail.com.

\section{Rondinele Aparecido Ribeiro}

Doutorando em Letras pela Universidade Estadual Paulista (UNESP/ASSIS). Licenciado em Letras pela Universidade Estadual do Norte do Paraná (UENP-PR). Contato: rondinele-ribeiro@bol.com.br

\section{Samanta Barreto Matos de Souza}

Professora - Secretaria de Estado de Educação do Maranhão. Doutoranda pela Pontifícia Universidade Católica de São Paulo (PUC/SP) no Programa de Literatura e Crítica Literária.

Lattes: http://lattes.cnpq.br/6009407858056518.

E-mail: samantabmatos@hotmail.com

\section{Waldenilson Teixeira Ramos}

Graduando em psicologia pela Universidade Federal Fluminense (UFF). Integrante dos grupos de iniciação científica "Subjetividade e verdade: modulações de verdade nos últimos cursos de Michel Foucault" e "Políticas e poéticas da transmissibilidade em Psicologia Social", ambos do Departamento de Psicologia da UFF. Professor voluntário de redação no departamento PreparaEnem, da ONG Grupo de Diversidade Niterói (GDN). E-mail: waldenilsonramos@id.uff.br 


\section{Hive \\ www.arcoeditores.com}

(2) contato@arcoeditores.com 19 arcoeditores $\bigcirc$

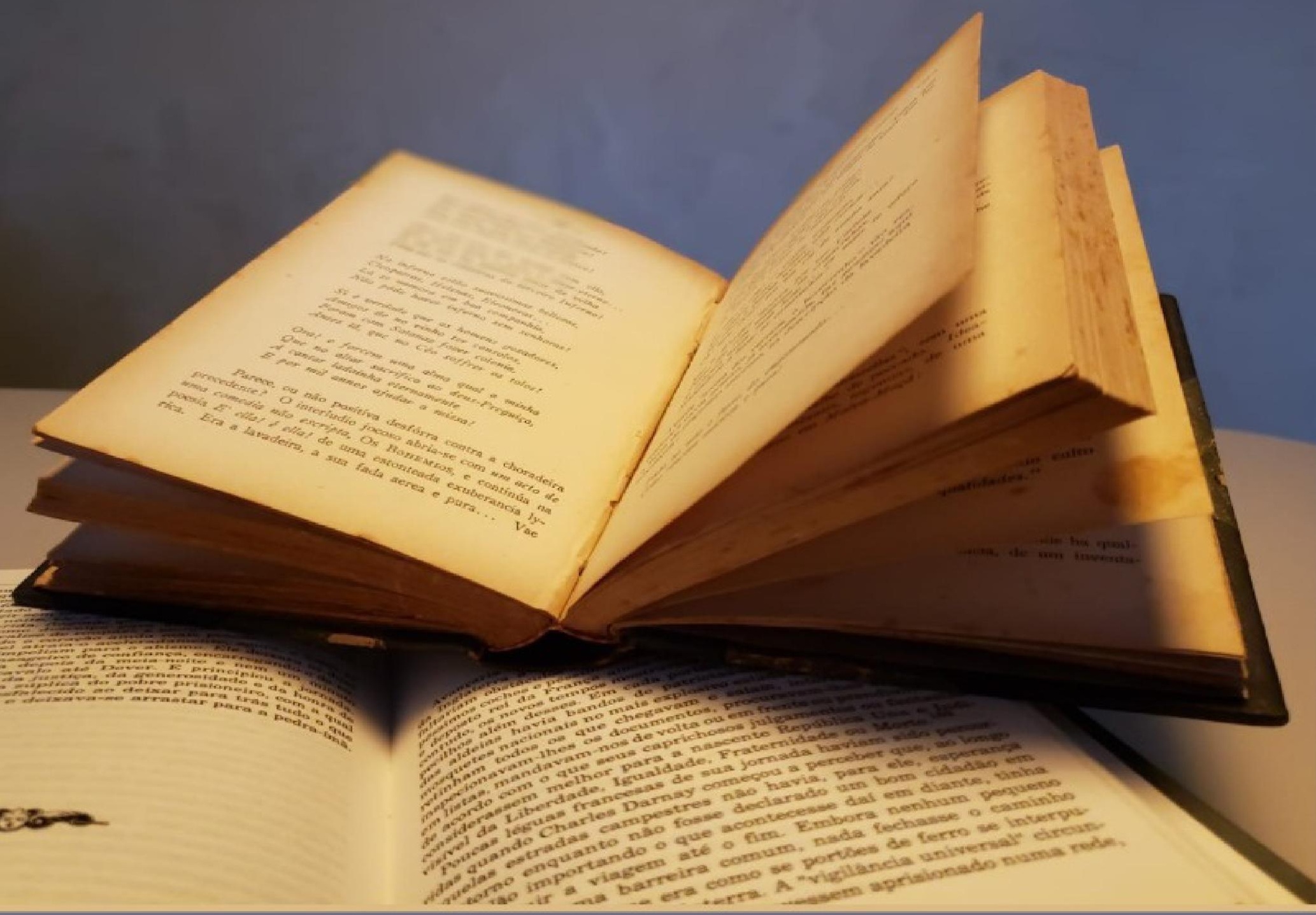

$A R C ?$

ISBN: 978-65-89949-16-9

$E$

9

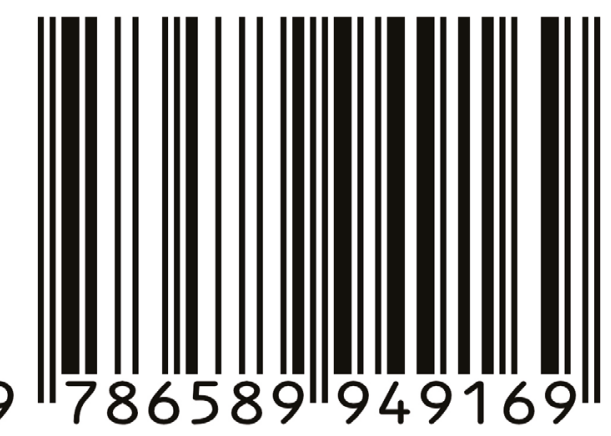

